Prepared in cooperation with Northwest Florida Water Management District, Suwannee River Water Management District, St. Johns River Water Management District, South Florida Water Management District, Southwest Florida Water Management District, and Tampa Bay Water

\title{
Evaluation of Actual Evapotranspiration Rates from the Operational Simplified Surface Energy Balance (SSEBop) Model in Florida and Parts of Alabama and Georgia, 2000-17
}

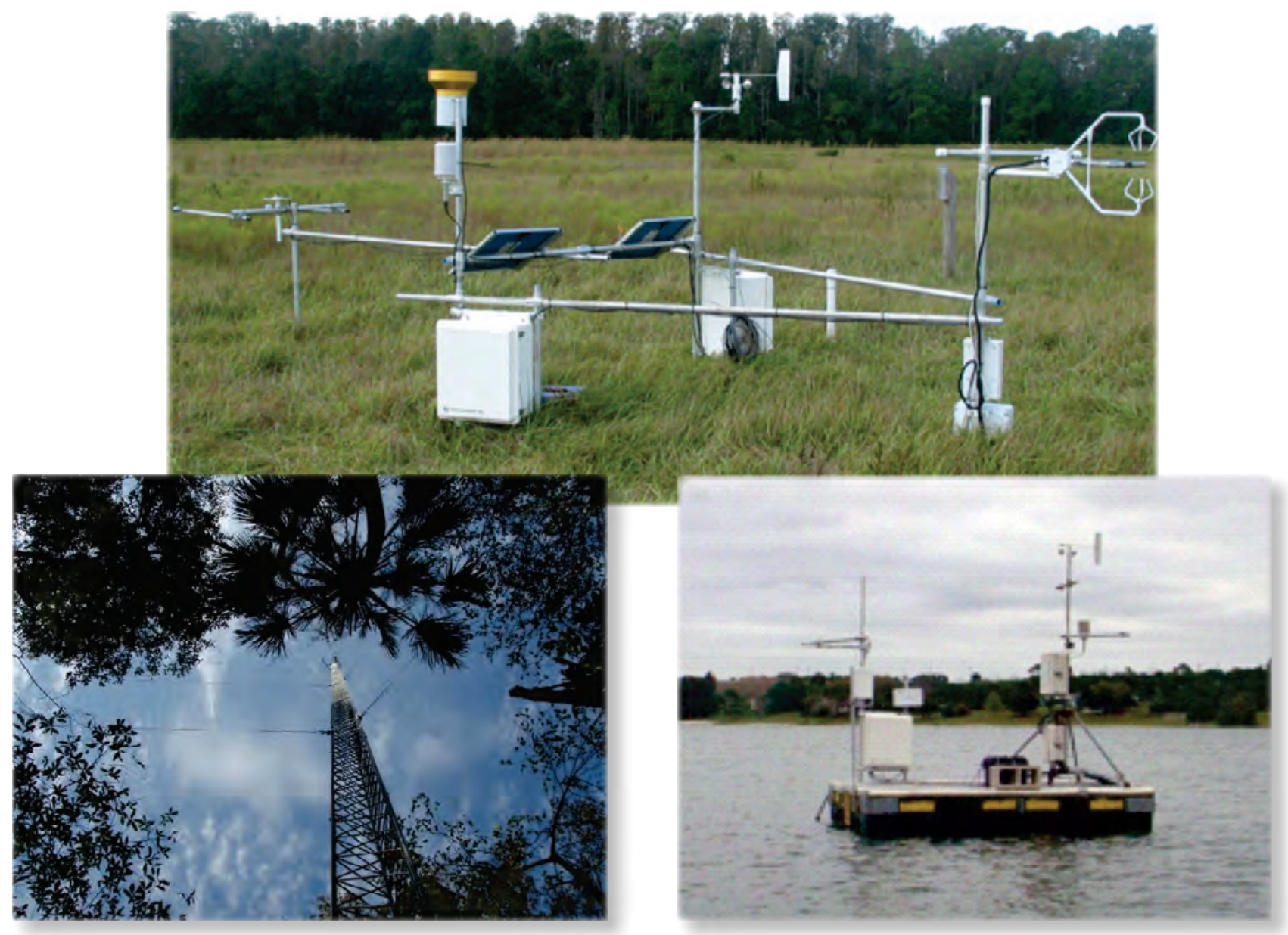

Scientific Investigations Report 2021-5072 
Cover. See figure 6. 


\section{Evaluation of Actual Evapotranspiration Rates from the Operational Simplified Surface Energy Balance (SSEBop) Model in Florida and Parts of Alabama and Georgia, 2000-17}

By Nicasio Sepúlveda

Prepared in cooperation with Northwest Florida Water Management

District, Suwannee River Water Management District, St. Johns River Water Management District, South Florida Water Management District, Southwest Florida Water Management District, and Tampa Bay Water

Scientific Investigations Report 2021-5072 


\section{U.S. Geological Survey, Reston, Virginia: 2021}

For more information on the USGS - the Federal source for science about the Earth, its natural and living resources, natural hazards, and the environment—visit https://www.usgs.gov or call 1-888-ASK-USGS.

For an overview of USGS information products, including maps, imagery, and publications, visit https://store.usgs.gov/.

Any use of trade, firm, or product names is for descriptive purposes only and does not imply endorsement by the U.S. Government.

Although this information product, for the most part, is in the public domain, it also may contain copyrighted materials as noted in the text. Permission to reproduce copyrighted items must be secured from the copyright owner.

Suggested citation:

Sepúlveda, N., 2021, Evaluation of actual evapotranspiration rates from the Operational Simplified Surface Energy Balance (SSEBop) model in Florida and parts of Alabama and Georgia, 2000-17: U.S. Geological Survey Scientific Investigations Report 2021-5072, 66 p., https://doi.org/10.3133/sir20215072.

Associated data for this publication:

Sepúlveda, N., 2021, Data sets of actual evapotranspiration rates from 2000 to 2017 for basins in Florida and parts of Alabama and Georgia, calculated using the water-balance method, the bias-corrected Operational Simplified Surface Energy Balance (SSEBop) model, and the land-use crop coefficients model: U.S. Geological Survey data release, https://doi.org/10.5066/P99AB3X4.

ISSN 2328-0328 (online) 


\section{Acknowledgments}

The author wants to acknowledge the Northwest Florida Water Management District (WMD), Suwannee River WMD, St. Johns River WMD, Southwest Florida WMD, South Florida WMD and Tampa Bay Water for their financial support and technical feedback provided during the duration of this study. The technical assistance of Jeff Geurink of Tampa Bay Water, Fatih Gordu and Yanbing Jia of St. Johns River WMD, and Yirgalem Assegid of South Florida WMD is greatly appreciated.

Technical suggestions by U.S. Geological Survey (USGS) personnel Gabriel B. Senay, Jason Bellino, W. Barclay Shoemaker, John F. Stamm, and Dave M. Sumner are appreciated. Stefanie Kagone of the USGS Earth Resources Observation and Science Center is thanked for providing the Operational Simplified Surface Energy Balance data products. 



\section{Contents}

Acknowledgments ……...................................................................................................................

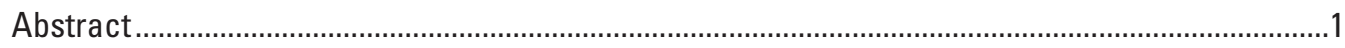

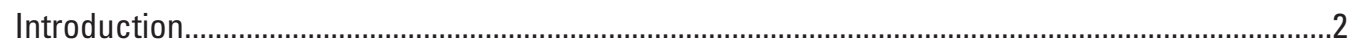

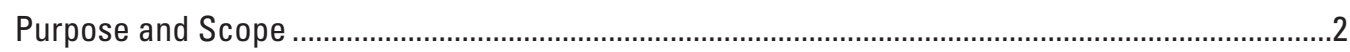

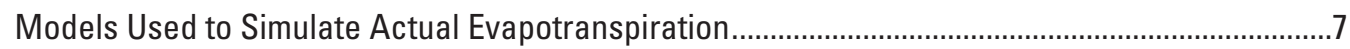

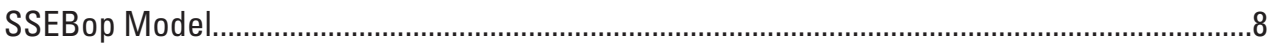

Actual ET Computed from MEF Station Data …………........................................................

Computing Bias in SSEBop ETa ...................................................................................14

Land-Use Type Data Sources ........................................................................................16

Actual ET Calculated with Generalized Land-Use Model.......................................................17

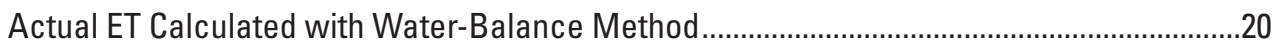

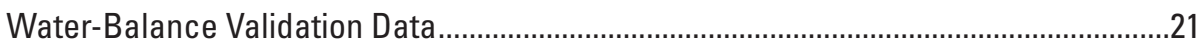

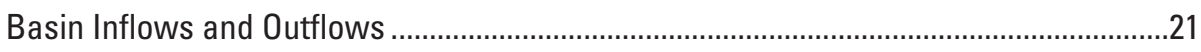

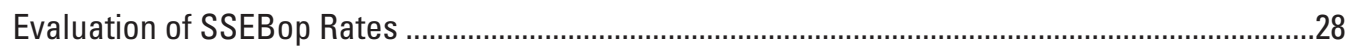

Evaluation of SSEBop Rates at the Point Scale................................................................

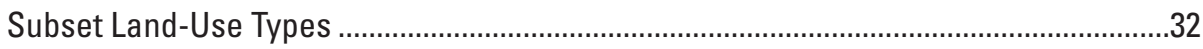

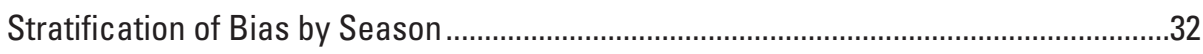

Least-Squares Regression Equations Stratified by Land-Use Type......................................32

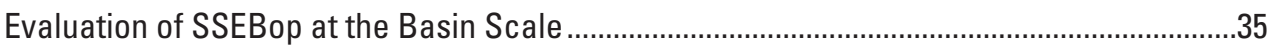

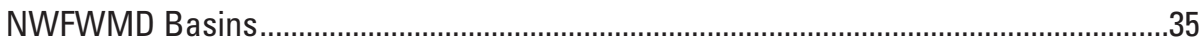

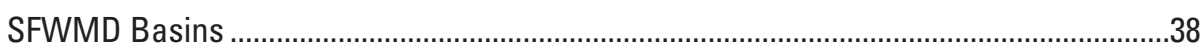

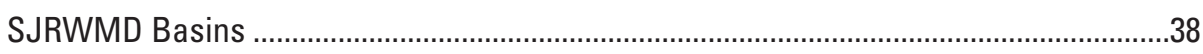

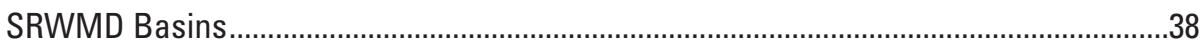

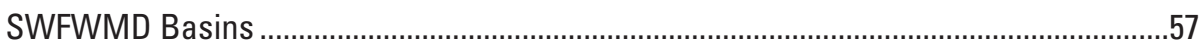

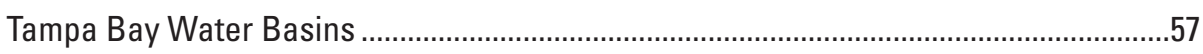

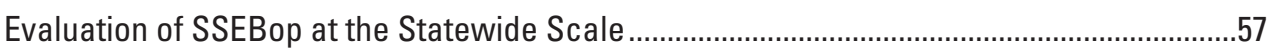

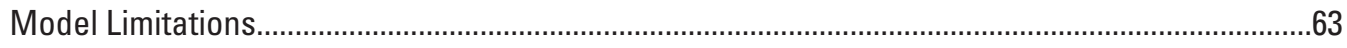

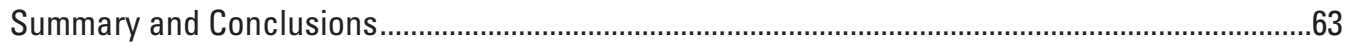

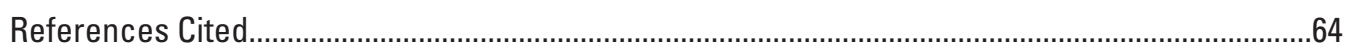

\section{Figures}

1. Map showing location of micrometeorological stations in Florida used to calculate actual evapotranspiration, operating within the period $2000-17 \ldots \ldots \ldots \ldots \ldots \ldots \ldots . . .6$

2. Map showing delineation of 55 basins in Florida and parts of Alabama and Georgia over which the water-balance method was applied.

3. Schematic diagram showing the variables used to calculate the Operational Simplified Surface Energy Balance actual evapotranspiration rates from satellite data

4. Map showing spatial distribution of annual (2006) rates for Operational Simplified Surface Energy Balance (SSEBop) actual evapotranspiration for the study area, reference evapotranspiration (ETo) used to calculate SSEBop rates for the study area, and ETo from the statewide daily reference and potential evapotranspiration gridded dataset for Florida 
5. Map showing the generalized land-use types and percentage of total area in Florida and parts of Alabama and Georgia, 2006..

6. Photographs showing the instrumentation used to record data required to compute actual evapotranspiration at MEF stations located in pasture with shallow depth to water of generally 5 feet or less, open-water surface, and forested wetland with high canopy density.....

7. Map showing the spatial distribution of shallow and deep water-table conditions in Florida and parts of Alabama and Georgia.

8. Graph showing monthly uncorrected Operational Simplified Surface Energy Balance evapotranspiration rates versus actual evapotranspiration rates measured at four micrometeorological stations located in the generalized land-use type of open-water surface, 2000-17

9. Graph showing average monthly ratios of actual evapotranspiration rates computed by using micrometeorological station data to reference evapotranspiration rates for generalized land-use types.

10. Schematic diagram illustrating general inflows and outflows used in the water-balance method applied to a basin

11. Graphs showing monthly uncorrected Operational Simplified Surface Energy Balance actual evapotranspiration (ETa) rates versus evapotranspiration rates calculated from micrometeorological station data for all station locations and all land uses, and bias-corrected monthly Operational Simplified Surface Energy Balance ETa rates versus actual evapotranspiration rates measured at all evapotranspiration stations.

12. Graph showing monthly uncorrected Operational Simplified Surface Energy Balance actual evapotranspiration rates versus actual evapotranspiration rates computed by using observations at micrometeorological stations located in the generalized land-use type of forested wetland...

13. Graph showing monthly uncorrected Operational Simplified Surface Energy Balance actual evapotranspiration rates versus actual evapotranspiration rates computed by using data at micrometeorological stations located in the generalized land-use type of pasture.

14. Graphs showing actual evapotranspiration computed by using micrometeorological station data and uncorrected Operational Simplified Surface Energy Balance rates at locations of micrometeorological stations in agricultural land-use types for spring, summer, fall, and winter, and corresponding seasonal bias-corrected Operational Simplified Surface Energy Balance rates for spring, summer, fall, and winter.

15. Graphs showing actual evapotranspiration computed by using micrometeorological station data and uncorrected Operational Simplified Surface Energy Balance rates at locations of micrometeorological stations in open-water surface surfaces for spring, summer, fall, and winter, and corresponding seasonal bias-corrected Operational Simplified Surface Energy Balance rates for spring, summer, fall, and winter...

16. Graphs showing bias versus SSEBop ${ }_{u}$ rates, residuals versus bias-corrected SSEBop rates, and bias-corrected annual SSEBop rate to annual rainfall ratio versus annual average rainfall at locations of micrometeorological stations in land-use type of agriculture.

17. Graphs showing bias versus SSEBop ${ }_{u}$ rates, residuals versus bias-corrected SSEBop rates, and bias-corrected annual SSEBop rate to annual rainfall ratio versus annual rainfall at locations of micrometeorological station in land-use type of forest. 
18. Graphs showing bias versus SSEBop ${ }_{u}$ rates, residuals versus bias-corrected SSEBop rates, and bias-corrected annual SSEBop rate to annual rainfall ratio versus annual average rainfall at locations of micrometeorological stations in land-use type of forested wetland with low to medium canopy density...

19. Graphs showing bias versus SSEBop ${ }_{u}$ rates, residuals versus bias-corrected SSEBop rates, and bias-corrected annual SSEBop rate to annual rainfall ratio versus annual rainfall at locations of micrometeorological station in land-use type of forested wetland with high canopy density.

20. Graphs showing bias versus SSEBop ${ }_{u}$ rates, residuals versus bias-corrected SSEBop rates, and bias-corrected annual SSEBop rate to annual rainfall ratio versus annual average rainfall at locations of meteorological stations in land-use type of marsh....

21. Graphs showing bias versus SSEBop ${ }_{u}$ rates, residuals versus bias-corrected SSEBop rates, and bias-corrected annual SSEBop rate to annual rainfall ratio versus annual rainfall for location of micrometeorological station in the land-use type of deep-water-table pasture

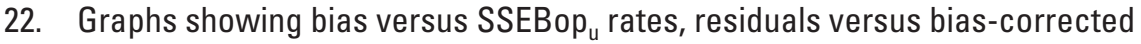
SSEBop rates, and bias-corrected annual SSEBop rate to annual rainfall ratio versus annual rainfall at locations of micrometeorological stations in the land-use type of shallow-water-table pasture

23. Graphs showing bias versus SSEBop ${ }_{u}$ rates, residuals versus bias-corrected SSEBop rates, and bias-corrected annual SSEBop rate to annual rainfall ratio versus annual rainfall at location of micrometeorological station in the land-use type of urban

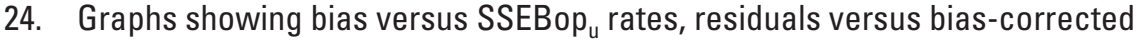
SSEBop rates, and bias-corrected annual SSEBop rate to annual rainfall ratio versus annual average rainfall at locations of micrometeorological stations in land-use type of open-water surface.

25. Map showing spatial distribution of residuals in actual evapotranspiration rates between the bias-corrected Operational Simplified Surface Energy Balance and the water-balance methods for all selected basins in the study area

26. Map showing basin delineations, streamgages at the basin inlets and outlets, surficial and Upper Floridan aquifer wells, major streams, and selected lakes in basins $1-5$ in the Northwest Florida Water Management District.

27. Map showing basin delineations, streamgages at the basin inlets and outlets, surficial and Upper Floridan aquifer wells, and major streams in basins 6-10 in the South Florida Water Management District.

28. Map showing basin delineations, streamgages at the basin inlets and outlets, surficial aquifer wells, Upper Floridan aquifer springs, and major streams and lakes in basins 11-21 in the St. Johns River Water Management District .....

29. Map showing basin delineations, streamgages at the basin outlets, surficial aquifer wells, Upper Floridan aquifer springs, and major streams and lakes in basins 22-29 in the St. Johns River Water Management District.

30. Map showing basin delineations, streamgages at the basin outlets, location of Upper Floridan aquifer wells, and major streams in basins 30-35 in the Suwannee River Water Management District

31. Map showing basin delineations, streamgages at the basin outlets, surficial and Upper Floridan aquifer wells, Upper Floridan aquifer springs, and major streams and lakes in basins 36-47 in the Southwest Florida Water Management District. 
32. Map showing basin delineations, streamgages at the basin outlets, surficial and Upper Floridan aquifer wells, and major streams in basins $48-55$ in the Tampa Bay Water area

33. Map showing spatial distribution of Operational Simplified Surface Energy Balance (SSEBop) actual evapotranspiration (ETa) rates for 2006 before bias corrections, SSEBop ETa rates for 2006 after bias corrections, and land-use-derived ETa rates for 2006 for Florida and parts of Alabama and Georgia ......60

\section{Tables}

1. Name, period of record, and location of micrometeorological evapotranspiration flux stations in Florida operating within the period 2000-17 .............3

2. Name, area, and identification number of basins in Florida and parts of Alabama and Georgia over which the water-balance method was applied

3. Year and source of land-use type datasets from water management districts' data portals used for each simulation year, 2000-17.

4. Percentage of total study area of each generalized land-use type for each group of years for which land-use surveys were available in the 2000-17 period, and total area of each generalized land-use type for the same group of years

5. Florida Land Use and Cover Classification System codes used to assign generalized land-use types

6. Upper Floridan aquifer springs, USGS National Water Information System station identification, and basin number where spring is located

7. Surficial and Upper Floridan aquifer wells used to determine changes in basin storage and leakage rates in Northwest Florida Water Management District and South Florida Water Management District basins.

8. Surficial and Upper Floridan aquifer wells used to determine changes in basin storage and leakage rates in Southwest Florida Water Management District basins

9. Surficial and Upper Floridan aquifer wells used to determine changes in basin storage and leakage rates in Tampa Bay Water basins

10. Surficial aquifer wells used to determine changes in basin storage in St. Johns River Water Management District basins

11. Upper Floridan aquifer wells used to determine changes in basin storage in Suwannee River Water Management District basins

12. Regression and error statistics between actual evapotranspiration computed by using micrometeorological station data and Operational Simplified Surface Energy Balance rates before and after bias corrections for each generalized land-use type

13. Ranges of uncorrected SSEBop (SSEBop ${ }_{u}$ ) actual evapotranspiration (ETa) rates, bias-corrected Operational Simplified Surface Energy Balance (SSEBop) ETa rates, actual evapotranspiration computed by using micrometeorological station data (mETa) minus SSEBop ${ }_{u}$, and mETa minus SSEBop for each generalized land-use type.

14. Basins, streamgages at basin outlets, basin areas, average annual actual evapotranspiration rates over the 2000-17 period for the wbETa, land use, SSEBop, and SSEBop methods, and average residuals for each method relative to the wbETa rate 


\section{Conversion Factors}

U.S. customary units to International System of Units

\begin{tabular}{lcl}
\hline \multicolumn{1}{c}{ Multiply } & By & \multicolumn{1}{c}{ To obtain } \\
\hline inch (in.) & Length & \\
inch (in.) & 2.54 & centimeter $(\mathrm{cm})$ \\
foot (ft) & 25.4 & millimeter $(\mathrm{mm})$ \\
mile (mi) & 0.3048 & meter $(\mathrm{m})$ \\
\hline & 1.609 & kilometer $(\mathrm{km})$ \\
\hline square mile $\left(\mathrm{mi}^{2}\right)$ & Area & \\
square mile $\left(\mathrm{mi}^{2}\right)$ & 259.0 & hectare $(\mathrm{ha})$ \\
\hline & 2.590 & square kilometer $\left(\mathrm{km}{ }^{2}\right)$ \\
\hline cubic foot per second $(\mathrm{ft} / \mathrm{s})$ & Flow rate & \\
inch per year $(\mathrm{in} / \mathrm{yr})$ & 0.02832 & cubic meter per second $\left(\mathrm{m}^{3} / \mathrm{s}\right)$ \\
\hline
\end{tabular}

International System of Units to U.S. customary units

\begin{tabular}{lll}
\hline \multicolumn{1}{c}{ Multiply } & By & \multicolumn{1}{c}{ To obtain } \\
\hline millimeter $(\mathrm{mm})$ & Length & \\
meter $(\mathrm{m})$ & 0.03937 & inch (in.) \\
kilometer $(\mathrm{km})$ & 3.281 & foot (ft) \\
kilometer $(\mathrm{km})$ & 0.6214 & mile (mi) \\
meter $(\mathrm{m})$ & 0.5400 & mile, nautical (nmi) \\
& 1.094 & yard (yd) \\
\hline square kilometer $\left(\mathrm{km}^{2}\right)$ & Area & \\
\hline
\end{tabular}

\section{Datum}

Vertical coordinate information is referenced to the North American Vertical Datum of 1988 (NAVD 88). 


\section{Abbreviations}

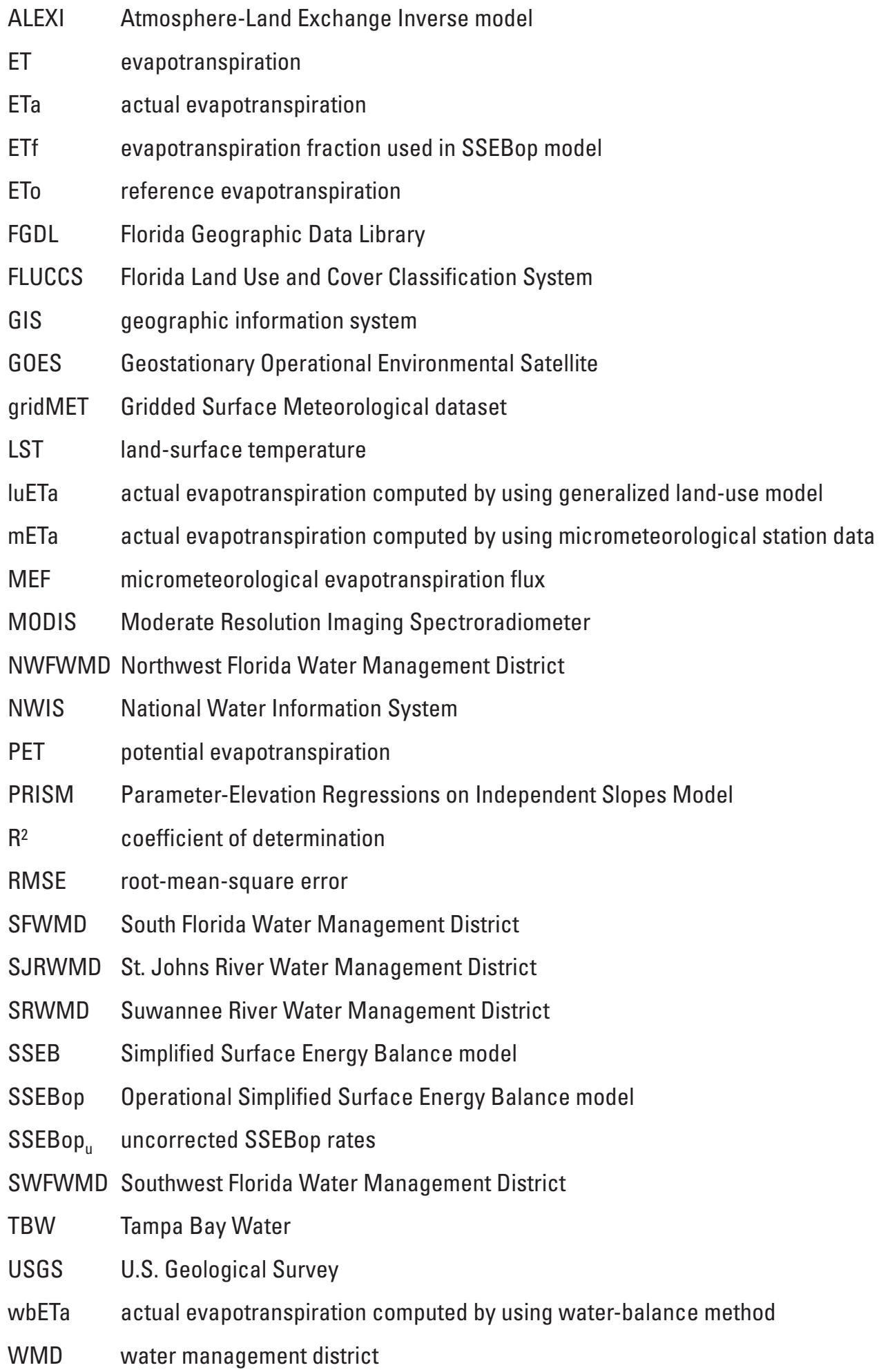




\title{
Evaluation of Actual Evapotranspiration Rates from the Operational Simplified Surface Energy Balance (SSEBop) Model in Florida and Parts of Alabama and Georgia, 2000-17
}

\author{
By Nicasio Sepúlveda
}

\section{Abstract}

Evapotranspiration (ET) is the water-vapor flux transported from the surface of the Earth into the atmosphere and is the sum of surface water directly evaporated and subsurface water transpired by plants. ET rates are commonly estimated by using potential or reference ET, which might differ from actual ET rates. Actual evapotranspiration (ETa) rates can be estimated by using the Operational Simplified Surface Energy Balance (SSEBop) model. This report evaluates SSEBop ETa rates at the point and basin scales in Florida and parts of Alabama and Georgia for 2000-17. ETa rates computed by using data from 24 micrometeorological stations in Florida are referred to as mETa rates and were used to quantify biases in the SSEBop ETa rates, stratified by generalized land-use type. Bias was computed as mETa minus SSEBop ETa rates for given generalized land-use types, and bias-correction equations were computed by using least-squares regressions. In addition to mETa rates at station locations, annual average ETa rates calculated from the application of a water-balance method to 55 basins in Florida and parts of Alabama and Georgia were used to assess the accuracy of the annual SSEBop ETa rates at the basin scale. Another independent model used to simulate ETa rates was based on monthly reference ET from the statewide daily reference evapotranspiration (ETo) gridded dataset for Florida computed by using Geostationary Operational Environmental Satellite estimates of solar radiation (GOES ETo). ETa at grid points was computed as monthly GOES ETo multiplied by ratios of monthly mETa to GOES ETo, computed at micrometeorological stations and stratified by each generalized land-use type.

The coefficient of determination $\left(\mathrm{R}^{2}\right)$ between monthly $\mathrm{mETa}$ and SSEBop ETa rates for all stations combined improved from 0.37 before bias correction of SSEBop ETa rates to 0.79 after the bias correction stratified by land-use type. For individual land-uses types, $\mathrm{R}^{2}$ varied from 0.59 for the monthly mETa at a station in the land-use type forest to
0.82 for the monthly mETa at stations in the land-use type shallow-water-table pasture. Root-mean-square error (RMSE) was computed as a function of the difference between SSEBop ETa rates and mETa rates. RMSE of monthly SSEBop ETa rates was 1.27 inches per month before the bias corrections improved to 0.73 inch per month after the bias corrections. RMSE for bias-corrected annual SSEBop ETa rates based on micrometeorological stations with complete years of records ranged from 2.01 inches per year (in/yr) for the land-use type of agriculture to $5.73 \mathrm{in} / \mathrm{yr}$ for the land-use type of deep water-table pasture, or 4.96 and 21.21 percent errors relative to annual mETa rates, respectively. Bias-corrected annual SSEBop ETa rates were also compared to annual ETa rates computed by using a water-balance method (wbETa) for 55 basins in Florida. Differences in bias-corrected average annual SSEBop ETa rates and average annual wbETa rates for the 55 basins ranged from -3.67 to $5.29 \mathrm{in} / \mathrm{yr}(-9.24$ to 17.36 percent). RMSE when computed as a function of the differences between annual SSEBop ETa rates and wbETa rates decreased, on average, from $4.13 \mathrm{in} / \mathrm{yr}$ for the uncorrected bias SSEBop ETa rates to $1.95 \mathrm{in} / \mathrm{yr}$ for the bias-corrected SSEBop rates. The average annual bias-corrected SSEBop ETa rates, from all basins, was $36.46 \mathrm{in} / \mathrm{yr}$ or 3.41 percent lower than the average annual wbETa rate of 37.79 inches.

Bias in SSEBop ETa rates varies based on time step (monthly versus annual), scale (point, basin, statewide), and land-use type. Applications to hydrologic models should consider bias relative to the inherent error in models. Biascorrected SSEBop ETa rates could be used as calibration targets in models of hydrologic processes, such as groundwater models. Annual bias in SSEBop ETa introduced to the model calibration is typically below the margin of error associated with typical residuals in model simulations, depending on scale. Surface-water and groundwater-flow models with RMSEs on the order of a few feet could benefit from biascorrected SSEBop values of ETa. 


\section{Introduction}

Evapotranspiration (ET) is the water-vapor flux transported from land surface to the atmosphere and is the sum of evaporated surface water and transpired subsurface water, both being driven largely by solar radiation. ET is one of the largest fluxes in the hydrologic budget for Florida (Sumner, 2006; Senay and others, 2008) and has the potential to be the largest flux during drought years and on open-water surfaces (German, 2000). Water-resource managers and modelers need reliable estimates of the spatial and temporal distribution of ET rates to simulate how the hydrologic budget varies and to implement water-management strategies in basins. Commonly, ET rates are estimated by using potential ET (PET) or reference ET (ETo). PET is evaporation from a horizontally uniform saturated surface where water was plentiful (Priestley and Taylor, 1972; Brutsaert, 1982). ETo is evapotranspiration from a hypothetical, well-watered grass reference crop with an assumed crop height of 0.12 meter, a fixed surface resistance of 70 seconds per meter and a surface albedo of 0.23 (Allen and others, 1998). Given that the underlying assumptions of PET and ETo (for example, ample water) are not always met, computed PET and ETo rates generally approximate an upper bound on actual ET rates (ETa).

The magnitude of ETa in the hydrologic budget can be computed from observations at micrometeorological evapotranspiration flux (MEF) stations in Florida (German, 2000; Shoemaker and others, 2011; Bracho and others, 2012; Swancar, 2015, 2016, 2017a, 2017b; Sumner, 2017; Shoemaker, 2018; U.S. Geological Survey [USGS], 2018a, 2018b; Wacker and Shoemaker, 2018). MEF stations provide point estimates of ETa for a given land use (such as forest, pasture, or urban). Regional estimates of ETa rates can be computed by using satellite-based sensors and associated methods. Some examples of satellite-based methods are the Atmosphere-Land Exchange Inverse method (ALEXI; Anderson and others, 2009), the Simplified Surface Energy Balance method (SSEB; Senay and others, 2007), the Operational Simplified Surface Energy Balance method (SSEBop; Senay and others, 2013; Savoca and others, 2013; Senay, 2018), and the Moderate Resolution Imaging Spectroradiometer (MODIS) land method (Zhang and others, 2010). ETa can also be estimated for specific crops or land-use types by using a "crop-coefficient" model, in which estimates of PET, or alternately ETo, are adjusted by coefficients associated with individual crops or land-use types (Allen and others, 1998; McBride and others, 2017; Sepúlveda and others, 2018). Lastly, ETa can be estimated at the basin scale and for longer time steps by using a water-balance method in which ETa is computed as a residual term after all other components of the water balance such as precipitation, runoff, and groundwater fluxes are quantified, as described by Senay and others (2013). The USGS, in cooperation with the Northwest Florida Water Management District, Suwannee River Water Management District, St. Johns River Water Management District, South Florida Water Management District, Southwest Florida Water Management District, and Tampa Bay Water, completed a study to evaluate ETa rates computed using the SSEBop model and evaluated the model by comparison with ETa rates computed at the MEF station scale and basin scale in Florida and parts of Alabama and Georgia.

\section{Purpose and Scope}

The purpose of this report is to evaluate monthly and annual ETa rates computed by the SSEBop model (Senay and others, 2013; Savoca and others, 2013; Senay, 2018) for the period 2000-17. SSEBop model output data are globally available at a 1-kilometer $(\mathrm{km})$ grid-point resolution, but this report is limited to Florida and parts of Alabama and Georgia. Bias analysis of SSEBop ETa rates is recommended for local applications, and bias could result from several situations such as when datasets have differences in spatial resolution, when ETa exceeds rainfall in water budget models, and when ETa calculations do not have closure in energy balance terms (Senay and others, 2020).

Hereinafter, "SSEBop ETa rates" will be referred to as "SSEBop rates." SSEBop rates were evaluated by comparison with other methods of computing ETa at point, statewide, and basin scales. ETa rates that were computed by using data from 24 micrometeorological evapotranspiration flux stations in Florida are hereinafter referred to as "mETa" rates (fig. 1, table 1). These mETa rates were stratified by land use and were used to evaluate SSEBop rates at the point scale and to compute bias. In addition, mETa data were used to compute "crop coefficients" based on land-use types that could be applied to ETo rates available from 2-km-resolution gridded datasets for Florida such as described by Mecikalski and others (2018), to estimate ETa at each 2-km grid point. Estimates of ETa based on crop coefficients for land-use types are referred to as the land-use model (luETa). The luETa was used to replace anomalous SSEBop rates, such as points with zero inches per month (in/mo) SSEBop rates, but was not further evaluated for bias, which is beyond the scope of this report. Lastly, a water-balance method was developed to estimate ETa (wbETa) for 55 basins in Florida, Alabama, and Georgia (fig. 2, table 2) for comparison to gridded SSEBop rates integrated over each basin area. The wbETa was computed as a residual term in the basin water-balance equation. 
Table 1. Name, period of record, and location of micrometeorological evapotranspiration flux (MEF) stations in Florida operating within the period $2000-17$.

[LU, generalized land-use type of MEF station; MM/YY, month and year; LON, longitude of MEF station in decimal degrees; LAT, latitude of MEF station in decimal degrees; SEQ, cell number of MEF station location relative to the nearly 1-square-kilometer uniform grid used in the study area, derived from the polygon grid used for the Operational Simplified Surface Energy Balance (SSEBop) actual evapotranspiration (ETa) rates; PIXEL, cell number of MEF station location relative to the $2 \times 2$ kilometer grid used for the Florida Geostationary Operational Environmental Satellite (GOES) evapotranspiration network; WMD, indicates water management district where MEF station is located; Stn. num., MEF station number assigned in figure 1; SFWMD, South Florida Water Management District; ENP, Everglades National Park; LMCD; low to medium canopy density; IFAS, Institute of Food and Agricultural Sciences; SWFWMD, Southwest Florida Water Management District; SJRWMD, St. Johns River Water Management District; WT, water table; HCD, high canopy density; UCF, University of Central Florida]

\begin{tabular}{|c|c|c|c|c|c|c|c|c|c|}
\hline $\begin{array}{l}\text { Stn. } \\
\text { num. }\end{array}$ & LU type & LU type description & Station name & $\begin{array}{l}\text { Period of record } \\
\text { (MM/YY-MM/YY) }\end{array}$ & LON & LAT & SEO & PIXEL & WMD \\
\hline 1 & Marsh & Sparse rushes & Old Ingraham Highway & $01 / 00-09 / 03$ & -80.63550 & 25.35750 & 651606 & 29323 & SFWMD \\
\hline 2 & Marsh & Thick sawgrass & ENP - X1.5 & $05 / 02-09 / 03$ & -80.93250 & 25.51050 & 636057 & 33574 & SFWMD \\
\hline 3 & Marsh & Sparse sawgrass & ENP - X2 & $01 / 01-10 / 03$ & -80.96850 & 25.54650 & 632605 & 34520 & SFWMD \\
\hline 4 & Marsh & Very sparse rushes & ENP - L1 & $01 / 01-10 / 03$ & -81.02250 & 25.60950 & 626565 & 36413 & SFWMD \\
\hline 5 & Marsh & Sparse sawgrass & Shark Valley Slough & $\begin{array}{l}01 / 00-12 / 01 \\
01 / 03-10 / 03\end{array}$ & -80.69850 & 25.61850 & 625739 & 36430 & SFWMD \\
\hline 6 & Marsh & Wet prairie & Wet Prairie & $11 / 07-09 / 10$ & -80.94150 & 25.74450 & 613644 & 39735 & SFWMD \\
\hline 7 & Forested wetland LMCD & Tall cypress strand & Cypress Swamp & $05 / 07-03 / 10$ & -81.10302 & 25.74851 & 613626 & 39727 & SFWMD \\
\hline 8 & Forested wetland LMCD & Dwarf cypress sawgrass & Dwarf Cypress & $05 / 07-03 / 10$ & -80.90550 & 25.76250 & 611924 & 40211 & SFWMD \\
\hline 9 & Marsh & Tall sawgrass marsh & Marsh & $07 / 07-03 / 10$ & -81.26550 & 26.19450 & 569646 & 52042 & SFWMD \\
\hline 10 & Agriculture & Immokalee IFAS row crop & Immokalee IFAS & $10 / 08-12 / 08$ & -81.44000 & 26.46111 & 544629 & 58669 & SFWMD \\
\hline 11 & Open-water surface & Lake Okeechobee & Lake Okeechobee & $12 / 12-12 / 16$ & -80.78850 & 26.90550 & 502463 & 70553 & SFWMD \\
\hline 12 & Agriculture & Citrus crop & Citrus Climate Station & $06 / 04-07 / 10$ & -81.77306 & 27.17833 & 476494 & 77612 & SWFWMD \\
\hline 13 & Marsh & Blue Cypress Marsh & Blue Cypress Marsh & $\begin{array}{l}01 / 00-09 / 03 \\
12 / 09-09 / 16\end{array}$ & -80.71650 & 27.69750 & 426615 & 91413 & SJRWMD \\
\hline 14 & Open-water surface & Lake & Lake Starr & $01 / 00-07 / 11$ & -81.58750 & 27.95625 & 401520 & 98477 & SWFWMD \\
\hline 15 & Pasture, shallow WT & Disney Preserve & Disney Preserve & $08 / 00-08 / 03$ & -81.40050 & 28.04850 & 392921 & 100857 & SFWMD \\
\hline 16 & Forested wetland HCD & Forested wetland & Dead River Forest & $12 / 09-02 / 16$ & -82.26222 & 28.12861 & 385067 & 102708 & SWFWMD \\
\hline 17 & Open-water surface & Lake & Lake Calm & 04/05-10/07 & -82.58333 & 28.14167 & 384170 & 103166 & SWFWMD \\
\hline 18 & Pasture, shallow WT & Pasture & Starkey Pasture & $05 / 03-04 / 16$ & -82.55917 & 28.22528 & 375552 & 105537 & SWFWMD \\
\hline 19 & Pasture, shallow WT & Sod farm & Duda Farms & $06 / 00-01 / 03$ & -80.77950 & 28.27350 & 371440 & 106578 & SJRWMD \\
\hline 20 & Open-water surface & Lake & Reedy Lake & $\begin{array}{c}01 / 02-07 / 04 \\
12 / 04-12 / 11 \\
11 / 15-12 / 17\end{array}$ & -81.61319 & 28.41611 & 357555 & 110326 & SFWMD \\
\hline 21 & Urban & WUCF Antenna & UCF tower & 01/09-09/12 & -81.20250 & 28.60650 & 340361 & 115088 & SJRWMD \\
\hline 22 & Pasture, deep WT & Pasture in deep WT & Ferris Farms & $\begin{array}{l}\text { 10/00-03/02; } \\
07 / 02-03 / 07\end{array}$ & -82.27611 & 28.76139 & 324726 & 119298 & SWFWMD \\
\hline 23 & Marsh & Wetland & Lyonia Preserve & $01 / 02-05 / 03$ & -81.22950 & 28.92150 & 309326 & 123618 & SJRWMD \\
\hline 24 & Forest & Pine Forest & Slash Pine Plantation & $\begin{array}{c}01 / 00-07 / 07 \\
01 / 09-12 / 10\end{array}$ & -82.24482 & 29.76480 & 228185 & 145843 & SJRWMD \\
\hline
\end{tabular}


Table 2. Name, area, and identification number of basins in Florida and parts of Alabama and Georgia over which the water-balance method was applied.

[WMD, water management district where most of the basin is located; POR, period of record of flow measurements used in the water-balance equation; NUM, unique basin number assigned in figure 2; NWFWMD, Northwest Florida Water Management District; NBI, no basin inlet; SFWMD, South Florida Water Management District; SJRWMD, St. Johns River Water Management District; SRWMD, Suwanee River Water Management District; SWFWMD, Southwest Florida Water Management District; SR, State Road; Blvd., Boulevard; TBW, Tampa Bay Water. Basin area is in square miles]

\begin{tabular}{|c|c|c|c|c|c|c|}
\hline NUM & Basin name & Basin area & $\begin{array}{c}\text { Streamgage } \\
\text { at basin } \\
\text { inlet }\end{array}$ & $\begin{array}{l}\text { Streamgage(s) at } \\
\text { basin outlet(s) }\end{array}$ & WMD & POR \\
\hline 1 & Lower Ochlockonee River & $1,188.884$ & 02328522 & 02330150,02327100 & NWFWMD & 2000-2017 \\
\hline 2 & Apalachicola-Chipola & $2,043.475$ & 02358000 & 02359170 & NWFWMD & 2000-2017 \\
\hline 3 & Lower Choctawhatchee River & $1,341.080$ & 02365200 & 02366500,02366650 & NWFWMD & 2000-2017 \\
\hline 4 & Yellow River & $1,360.291$ & NBI & 02369600 & NWFWMD & 2002-2017 \\
\hline 6 & Boggy Creek Swamp & 83.205 & NBI & 02262900 & SFWMD & 2003-2017 \\
\hline 7 & C-139 & 263.012 & NBI & No basin outlet & SFWMD & 2004-2017 \\
\hline 8 & Caloosahatchee & 829.602 & 02292010 & 02292900 & SFWMD & $2000-2015$ \\
\hline 9 & Reedy-Shingle Creek & 256.302 & NBI & 02264495,02266500 & SFWMD & $2001-2017$ \\
\hline 13 & St. Johns River at Melbourne & 939.818 & NBI & 02232000 & SJRWMD & 2001-2017 \\
\hline 14 & Pennywash Creek & 19.429 & NBI & 02232155 & SJRWMD & 2003-2017 \\
\hline 15 & Apopka Beauclair Canal & 196.101 & NBI & 02237700 & SJRWMD & 2000-2008 \\
\hline 16 & Ocklawaha Moss Bluff & 842.514 & NBI & 02238500 & SJRWMD & 2009-2017 \\
\hline 17 & Orange Creek at Orange Spring & 522.914 & NBI & 02243000 & SJRWMD & $2000-2017$ \\
\hline 18 & St. Johns River at Buffalo Bluff & $5,895.788$ & NBI & 02244040 & SJRWMD & $2000-2017$ \\
\hline 19 & Haw Creek above Russell Landing & 189.225 & NBI & 02244333 & SJRWMD & $2011-2017$ \\
\hline 20 & Tomoka River & 62.721 & NBI & 02247510 & SJRWMD & 2004-2017 \\
\hline 21 & Turkey Creek & 94.582 & NBI & 02250030 & SJRWMD & 2009-2017 \\
\hline 28 & Eau Gallie River & 4.684 & NBI & 02249007 & SJRWMD & 2009-2017 \\
\hline 29 & South Prong at St. Sebastian River & 56.277 & NBI & 02251000 & SJRWMD & 2009-2017 \\
\hline 30 & Alapaha & $1,671.834$ & NBI & 02317620 & SRWMD & $2000-2017$ \\
\hline 31 & Withlacoochee-SRWMD & $2,390.020$ & NBI & 02319394 & SRWMD & 2000-2017 \\
\hline 32 & Upper Suwannee River & $2,789.673$ & NBI & 02319500 & SRWMD & 2000-2017 \\
\hline 33 & Santa Fe River & $1,380.226$ & NBI & 02322800 & SRWMD & 2000-2017 \\
\hline 34 & Suwannee River & $9,533.277$ & NBI & 02323500 & SRWMD & $2000-2017$ \\
\hline 35 & Aucilla & 749.594 & NBI & 02326500 & SRWMD & $2000-2017$ \\
\hline 36 & Peace Creek Canal-Brush Lake & 171.568 & NBI & 02293987 & SWFWMD & 2000-2017 \\
\hline 37 & Saddle Creek at SR 542 near Lakeland & 59.381 & NBI & 02294217 & SWFWMD & $2000-2017$ \\
\hline 38 & Joshua Creek at Nocatee-Honey Run & 121.003 & NBI & 02297100 & SWFWMD & 2000-2017 \\
\hline
\end{tabular}


Table 2. Name, area, and identification number of basins in Florida and parts of Alabama and Georgia over which the water-balance method was applied.-Continued

[WMD, water management district where most of the basin is located; POR, period of record of flow measurements used in the water-balance equation; NUM, unique basin number assigned in figure 2; NWFWMD, Northwest Florida Water Management District; NBI, no basin inlet; SFWMD, South Florida Water Management District; SJRWMD, St. Johns River Water Management District; SRWMD, Suwanee River Water Management District; SWFWMD, Southwest Florida Water Management District; SR, State Road; Blvd., Boulevard; TBW, Tampa Bay Water. Basin area is in square miles]

\begin{tabular}{rlrllll}
\hline NUM & \multicolumn{1}{c}{ Basin name } & Basin area & $\begin{array}{c}\text { Streamgage } \\
\text { at basin } \\
\text { inlet }\end{array}$ & $\begin{array}{c}\text { Streamgage(s) at } \\
\text { basin outlet(s) }\end{array}$ & WMD & POR \\
\hline 39 & Prairie Creek at Fort Ogden & 245.561 & NBI & 02298123 & SWFWMD & $2000-2017$ \\
40 & Shell Creek near Punta Gorda & 133.915 & NBI & 02298202 & SWFWMD & $2000-2017$ \\
41 & Myakka River near Sarasota & 227.223 & NBI & 02298830 & SWFWMD & $2000-2017$ \\
42 & Big Slough at Tropicaire Blvd & 73.665 & NBI & 02299450 & SWFWMD & $2001-2017$ \\
43 & Manatee River at Fort Hamer & 206.318 & NBI & 02300021 & SWFWMD & $2006-2016$ \\
44 & Jumper Creek Canal near Bushnell & 39.819 & NBI & 02312640 & SWFWMD & $2012-2017$ \\
45 & Panasoffkee Lake Basin & 79.386 & NBI & 02312700 & SWFWMD & $2000-2017$ \\
46 & Withlacoochee River near Holder & $1,789.420$ & NBI & 02313000 & SWFWMD & $2004-2017$ \\
47 & Withlacoochee River Inglis and Bypass & $2,049.615$ & NBI & 02313230,02313250 & SWFWMD & $2004-2017$ \\
48 & Little Manatee River & 151.595 & NBI & 02300500 & TBW & $2000-2017$ \\
49 & North Prong Alafia River & 136.032 & NBI & 02301000 & TBW & $2000-2017$ \\
50 & South Prong Alafia River & 112.393 & NBI & 02301300 & TBW & $2000-2017$ \\
51 & Hillsborough River above Crystal Spring & 85.749 & 02311000 & 02301990 & TBW & $2000-2017$ \\
52 & Blackwater Creek near Knights & 98.616 & NBI & 02302500 & TBW & $2000-2017$ \\
53 & Cypress Creek and Trout Creek & 185.057 & NBI & 02303800,02303350 & TBW & $2000-2017$ \\
54 & Sweetwater Creek near Tampa & 24.436 & NBI & 02306647 & TBW & $2000-2017$ \\
55 & Anclote River near Elfers & 69.597 & NBI & 02310000 & TBW & $2000-2017$ \\
& Average & 798.838 & & & & \\
\hline
\end{tabular}




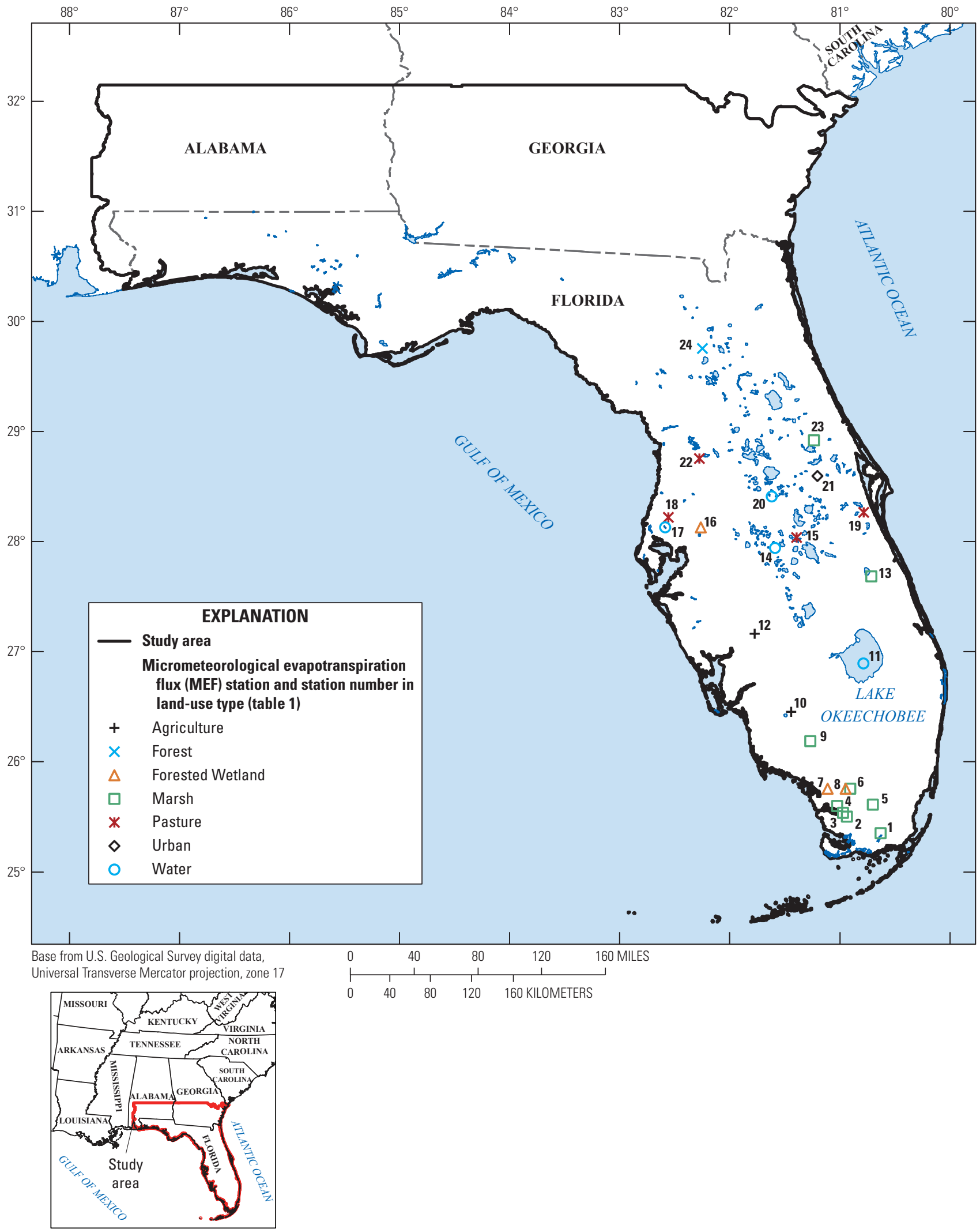

Figure 1. Location of micrometeorological stations in Florida used to calculate actual evapotranspiration, operating within the period 2000-17. 


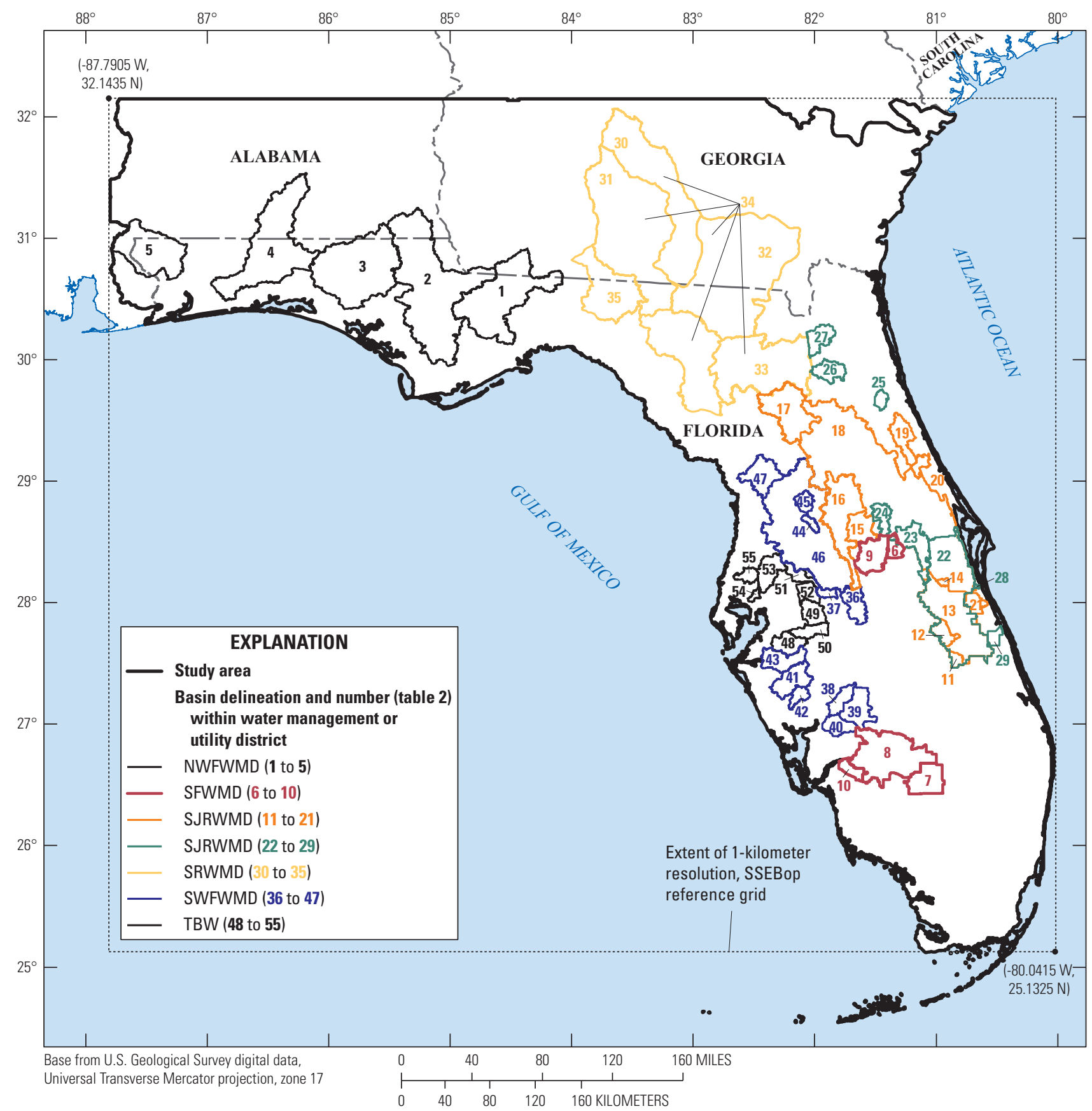

Figure 2. Delineation of 55 basins in Florida and parts of Alabama and Georgia over which the water-balance method was applied. [SSEBop, Operational Simplified Surface Energy Balance model; NWFWMD, Northwest Florida Water Management District; SFWMD, South Florida Water Management District; SRWMD, Suwanee River Water Management District; SJRWMD, St. Johns River Water Management District; SWFWMD, Southwest Florida Water Management District; TBW, Tampa Bay Water]

\section{Models Used to Simulate Actual Evapotranspiration}

The SSEBop model of ETa (Senay and others, 2013) for Florida and parts of Alabama and Georgia was evaluated in this report by comparison with
- mETa rates computed by using micrometeorological evapotranspiration flux station data in Florida,

- a generalized land-use model based on crop coefficients applied to ETo to compute luETa, and

- a simple water-balance method to compute wbETa. 
In this study, the SSEBop model is validated, over Florida and parts of Alabama and Georgia, at both the point and basin scales. Point-scale validation was performed using monthly MEF station ETa rates (2000-2017) stratified by generalized land-use type. Basin-scale validation was performed using average annual water-balance wbETa rates at 55 basins in the study area.

\section{SSEBop Model}

The SSEBop model (fig. 3; Savoca and others, 2013; Senay and others, 2013) estimates ETa rates at a 1-km grid resolution for land points at a monthly time step based on (1) land-surface temperature (LST) data from the MODIS satellite (USGS, 2018c), (2) ETo from the Gridded Surface Meteorological (gridMET) dataset (Abatzoglou, 2013), and (3) near-surface air temperature from Daymet (Thornton and others, 2016). The SSEBop rate is computed as the product of an evapotranspiration fraction (ETf) and ETo. ETf is a fraction bounded between 0 and 1 and is computed on the basis of near-surface air temperature and satellite-observed (MODIS) LST over a given clear-sky day or moving 8-day time period (Senay and others, 2013; Senay, 2018). ETf approaches 1 when the LST approaches a specified "cold-reference" LST (Senay, 2018): this would occur when soils are wet, associated sensible heat flux is small ("cold"), and latent heat flux is large. The cold-reference LST (Tc in fig. 3) can be derived from the daily maximum near-surface air temperature, such as from Daymet, or the 8-day period using a calibration coefficient established over well vegetated surfaces and that relates daily maximum air temperature to LST. The hot-reference LST can be approximated by adding a constant temperature difference (derived from net radiation data for a given location and day of the year) to the Tc (Senay and others, 2013). The formulation presented by Senay and others (2013) is a function of sensible heat flux only ("hot," latent, and ground heat fluxes are assumed to be zero).

Monthly SSEBop rates used in this study span the period from January 2000 to December 2017 for the study area. Monthly SSEBop rates were downloaded from the USGS Geo Data Portal (2020). The extent of the domain used for this study and the longitude and latitude coordinates of the upper left and lower right corner of the uniform grid used to reference all the estimated SSEBop rates described in this report are shown in figure 2 . The grid has equal longitude and latitude spacing of $0.009^{\circ}$ (hereinafter referred to as a $1-\mathrm{km}$ grid), 780 rows and 862 columns, and a span that covers the study area from southwest Alabama to the southeast coast of Georgia and Florida exclusive of the keys south of the peninsula. The ETo rates used to calculate the SSEBop rates were obtained from the gridMET dataset (Abatzoglou, 2013; University of California, 2020), which has a 1.25-arc-minute grid spacing.

Maps showing SSEBop rates and ETo in the study area for 2006 (fig. 4) illustrate the following general characteristics: (1) anomalous points, such as some areas along the Florida and Georgia coastline and identified as having SSEBop rates less than 5 inches per year (in/yr), (2) lower SSEBop rates for Lake Okeechobee than for areas south of the lake where marsh is the most prevalent land use, (3) SSEBop rates greater than 50 inches in areas not classified as open-water surfaces (fig. 4A), and (4) differences between the spatial distributions of the gridMET ETo (fig. $4 B$ ) rates used to calculate the SSEBop rates and the Geostationary Operational Environmental Satellite (GOES) ETo rates (fig. 4C) from the statewide daily reference and PET gridded dataset for Florida (Mecikalski and others, 2018; USGS, 2018a). The GOES ETo dataset is based on the use of GOES imagery to estimate solar radiation applied to the standard methodology for computing ETo as described by Allen and others (1998) and Mecikalski and others (2018). Anomalous monthly SSEBop rates were identified at about $0.5-5$ percent of $1-\mathrm{km}$ grid points, depending on month, and SSEBop rates at outlier grid points were replaced by luETa, which is further discussed in the "Actual ET Calculated with Generalized Land-Use Model" section. The gridMET ETo rates ranged from 54.04 to $74.49 \mathrm{in} / \mathrm{yr}$, a slightly higher range compared to the GOES ETo rates, which ranged from 49.37 to $68.42 \mathrm{in} / \mathrm{yr}$. These contrasting spatial variations in ETa rates illustrate the need to analyze SSEBop rates for potential biases. In addition, bias could be addressed by using alternative methods for computing ETo (and compute ETa by multiplying ETo and ETf), discussed later in this report.

\section{Actual ET Computed from MEF Station Data}

The mETa rates computed from data at 24 MEF stations with differing periods of record (table 1) at hourly or daily time steps are available in a related data release (Sepúlveda, 2021). Monthly mETa rates at stations 1-5 and 11 (fig. 1) were calculated by using the Bowen-ratio energy-budget method (German, 2000), and mETa rates at stations 6-10 and 12-24 were calculated by using the eddy-covariance method (Sumner, 2006, 2017; Shoemaker and others, 2011; Swancar, 2015, 2016, 2017a, 2017b; Sumner and others, 2017; Shoemaker, 2018). In the eddy-covariance method, the measured water-vapor flux is multiplied by the measured three-dimensional wind speed to calculate the ETa rate, but the Bowen-ratio method is based on estimating sensible and latent heat fluxes from total energy available for evapotranspiration and inferring sensible/latent heat flux partitioning of total energy based on measured vertical differentials for air temperature and vapor pressure at two points. German (2000) calculated ETa rates by using the Bowen-ratio and the eddycovariance methods at station 5 and obtained comparable ETa results from each method (German, 2000).

Stations were classified and stratified by seven generalized land-use types (fig. 5): agriculture, forest, forested wetland, marsh, pasture, urban, and open water using the land-use description for each site. Sources of land-use data are discussed in the "Land-Use Type Data Sources" section. There was no station in the land-use type of mining; however, 


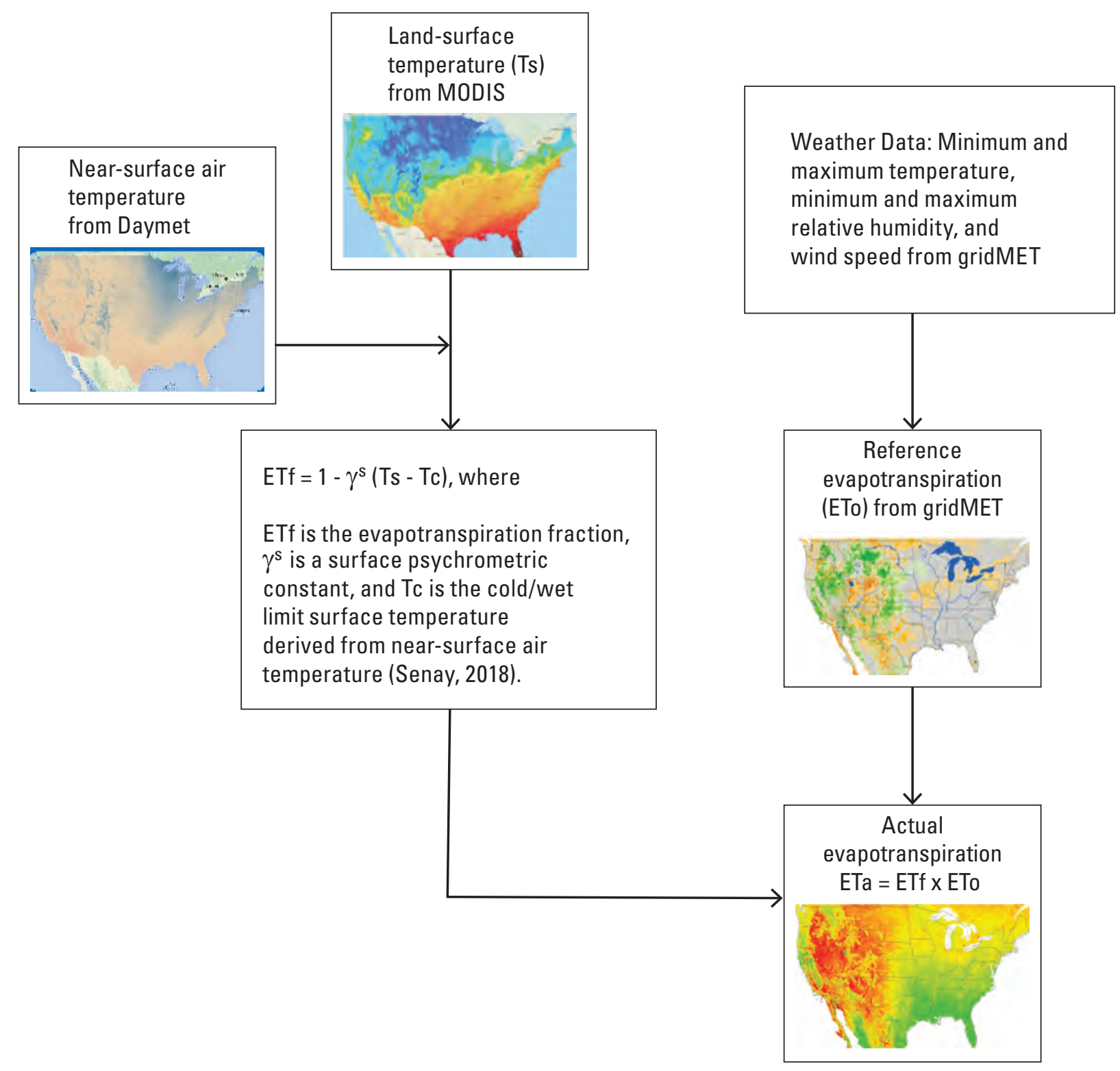

Figure 3. Variables used to calculate the Operational Simplified Surface Energy Balance (SSEBop) actual evapotranspiration (ETa) rates from satellite data. [MODIS, Moderate Resolution Imaging Spectroradiometer; gridMET, Gridded Surface Meteorological dataset; Daymet, Thornton and others (2016)]

mining was added as a generalized land-use type characterized by the combined effect of the generalized land-use types of pasture and open-water surface. The sources of the land-use data are listed in the "Land-Use Type Data Sources" section. Forested wetland was further subset by canopy density (low to medium and high), and pasture was subset by depth to water table (deep and shallow). Examples of MEF stations in a shallow-water-table pasture, open-water surface, and forested wetland with high canopy density are shown in figures $6 A-C$, respectively.

Soil surveys can be used to identify areas of shallow or deep groundwater conditions in the unconfined aquifer. Soils identified by the Natural Resources Conservation
Service (2020) as hydrologic soil group A were assumed to represent deep water-table conditions while the remaining hydrologic soil groups $(\mathrm{B}, \mathrm{C}, \mathrm{D}, \mathrm{A} / \mathrm{D}, \mathrm{B} / \mathrm{D}$, and $\mathrm{C} / \mathrm{D})$ were assumed to represent soils under shallow water-table conditions. Hydrologic soil group A is characterized by a low runoff potential when thoroughly wet and by a saturated hydraulic conductivity for all soil layers of at least 11.34 feet per day (ft/d). These two soil properties were the basis of the assumption of deep water-table conditions (2 feet or more below land surface). Hydrologic soil groups B, C, and D are characterized by moderately low runoff, moderately high runoff, and high runoff potential when thoroughly wet, respectively, and by a saturated hydraulic conductivity of less than 


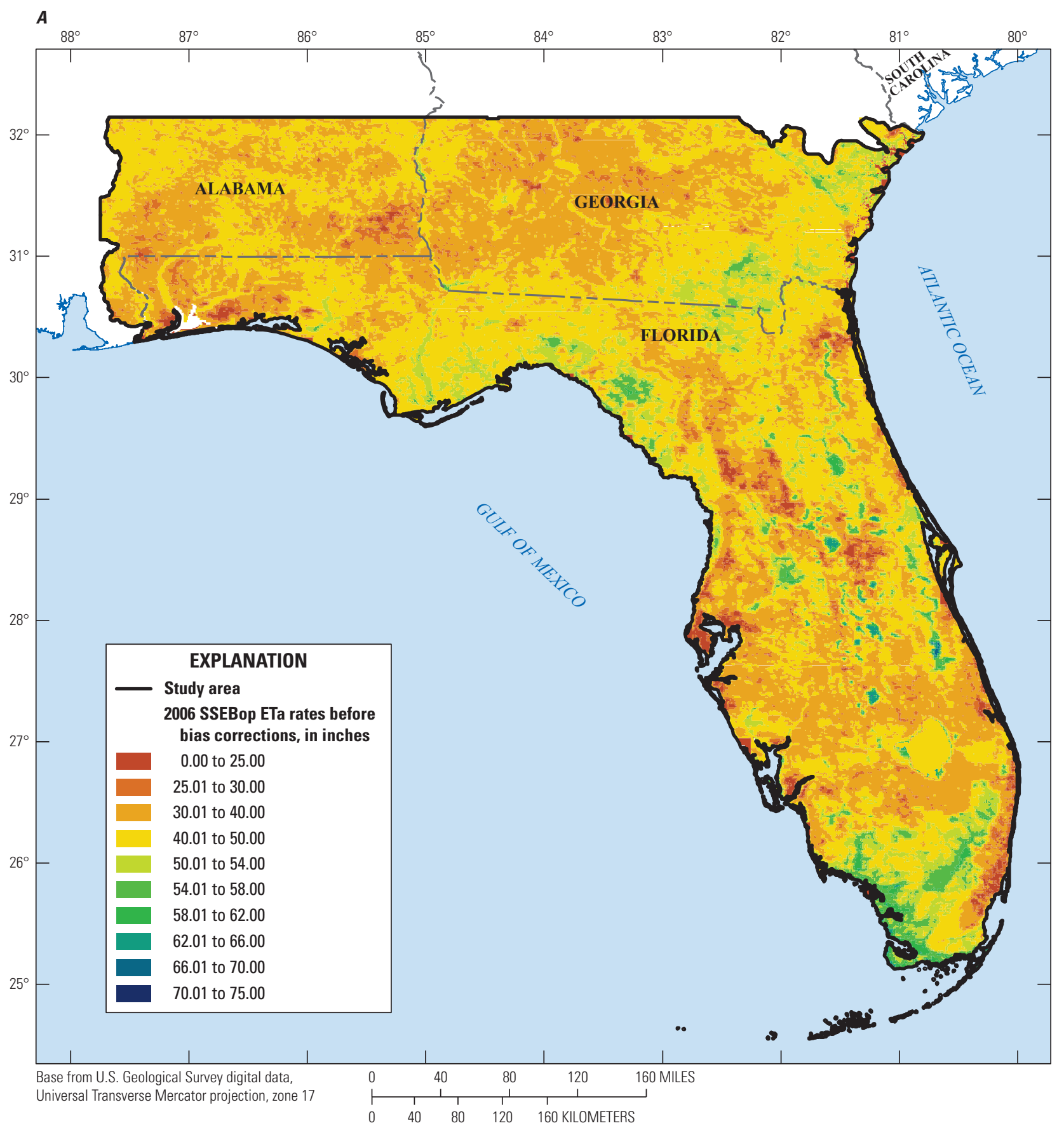

Figure 4. Spatial distribution of annual (2006) rates for, $A$, Operational Simplified Surface Energy Balance (SSEBop) actual evapotranspiration (ETa) for the study area, $B$, reference evapotranspiration (ETo) used to calculate SSEBop rates for the study area, and $C$, ETo from the statewide daily reference and potential evapotranspiration gridded dataset for Florida. [GOES, Geostationary Operational Environmental Satellite; ET, evapotranspiration] 


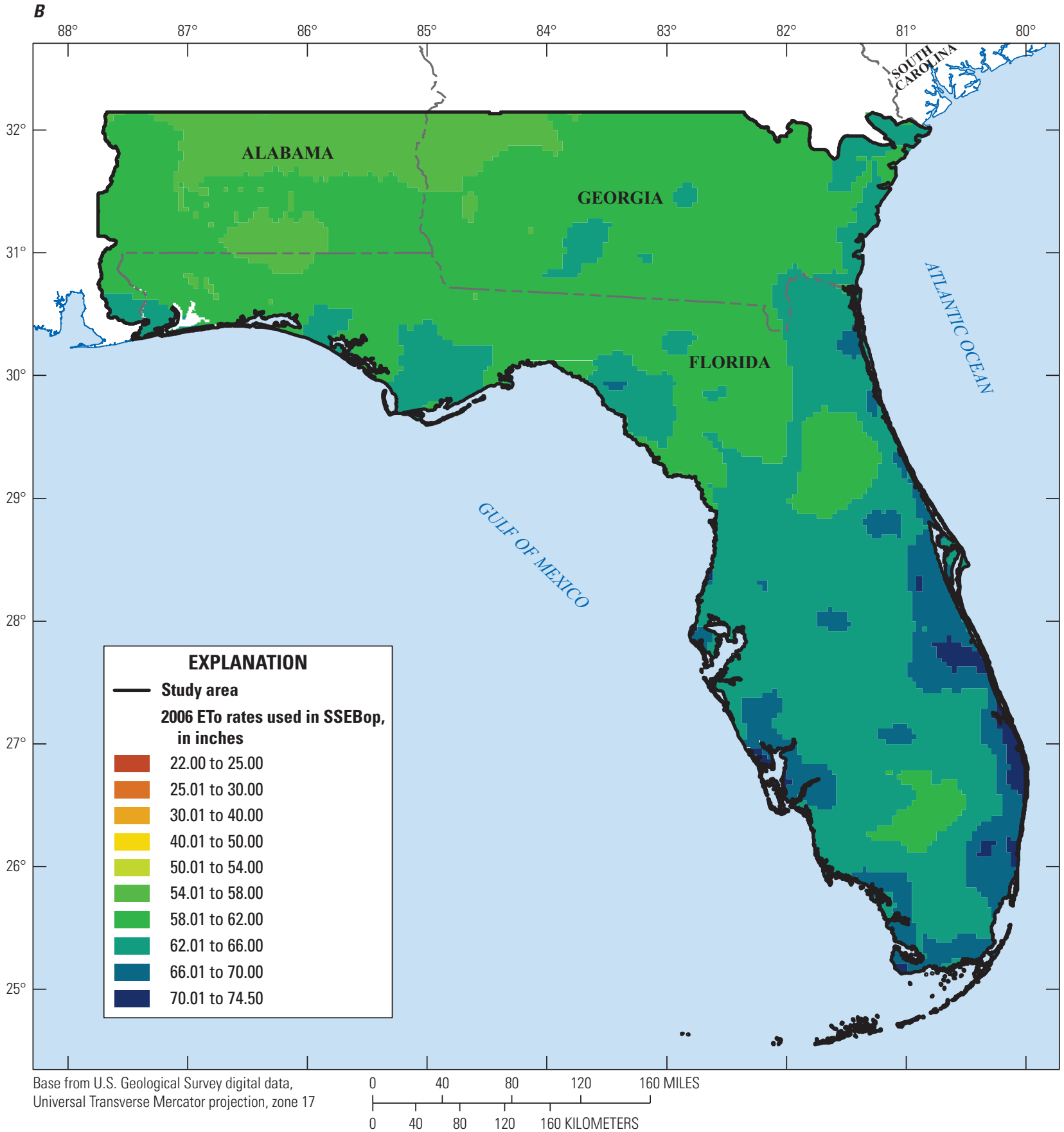

Figure 4. Spatial distribution of annual (2006) rates for, $A$, Operational Simplified Surface Energy Balance (SSEBop) actual evapotranspiration (ETa) for the study area, $B$, reference evapotranspiration (ETo) used to calculate SSEBop rates for the study area, and $C$, ETo from the statewide daily reference and potential evapotranspiration gridded dataset for Florida. [GOES, Geostationary Operational Environmental Satellite; ET, evapotranspiration]—Continued 


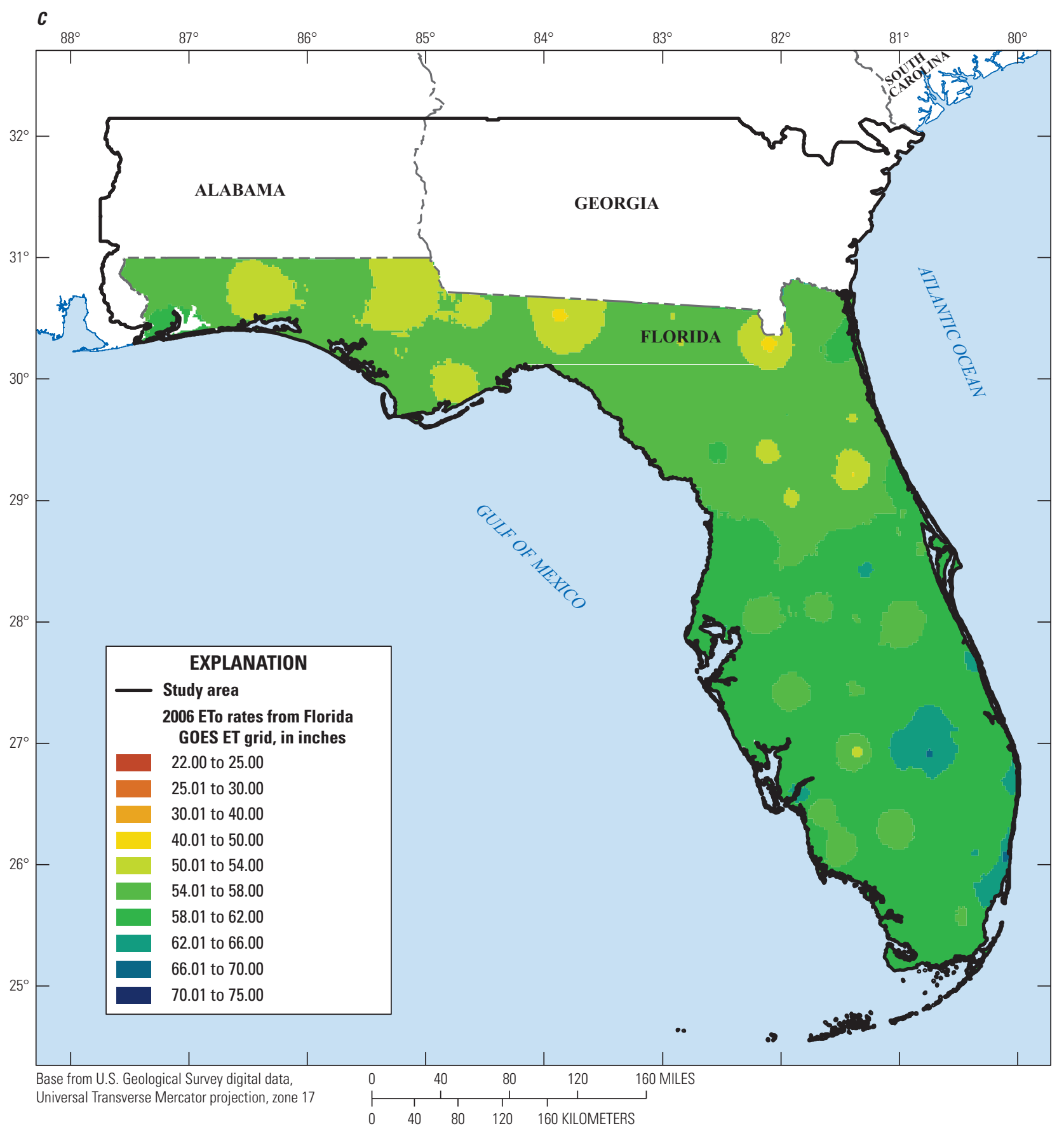

Figure 4. Spatial distribution of annual (2006) rates for, $A$, Operational Simplified Surface Energy Balance (SSEBop) actual evapotranspiration (ETa) for the study area, $B$, reference evapotranspiration (ETo) used to calculate SSEBop rates for the study area, and $C$, ETo from the statewide daily reference and potential evapotranspiration gridded dataset for Florida. [GOES, Geostationary Operational Environmental Satellite; ET, evapotranspiration]—Continued 


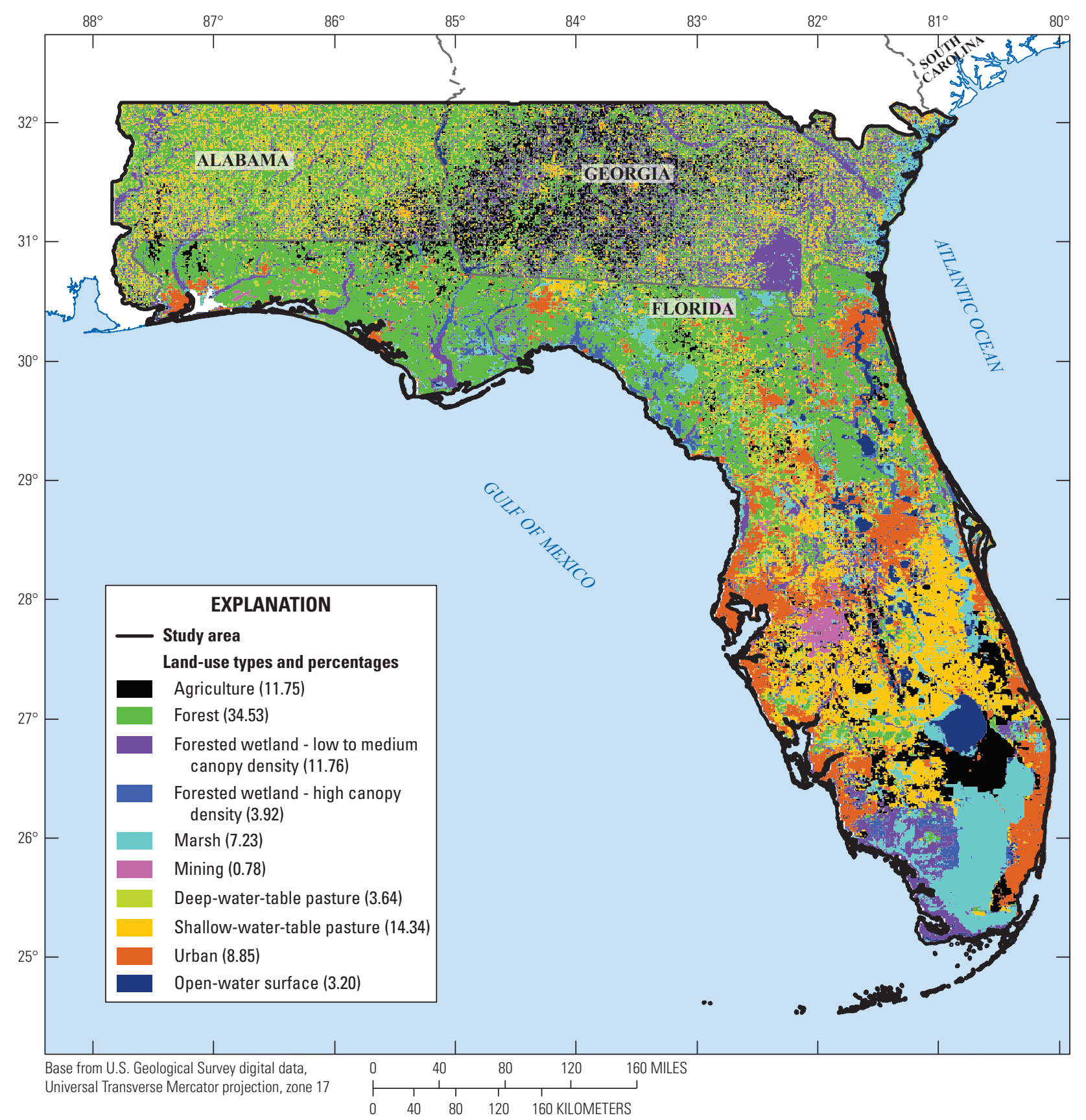

Figure 5. Generalized land-use types and percentage of total area in Florida and parts of Alabama and Georgia, 2006.

$11.34 \mathrm{ft} / \mathrm{d}$ based on classification by the U.S. Department of Agriculture (USDA, 2007, https://directives.sc.egov.usda.gov/ OpenNonWebContent.aspx?content=17757.wba). Soils that can be adequately drained are assigned dual hydrologic soil groups $\mathrm{A} / \mathrm{D}, \mathrm{B} / \mathrm{D}$, and $\mathrm{C} / \mathrm{D}$ based on their saturated hydraulic conductivity and undrained conditions.

The spatial distribution of deep water-table areas was further refined in the St. Johns River Water Management District (SJRWMD) area by using updated soil maps from the SJRWMD database (B. Powell, SJRWMD, written commun., 2019). The spatial distribution of deep and shallow water-table areas for this study (fig. 7) was applied to the entire 2000-17 period. About 82 percent of the study area was classified as having shallow water-table conditions, and the remaining 18 percent was classified as having deep water-table conditions. While the spatial distribution of water-table conditions could change from year to year and even from season to season, a single set of water-table conditions was used for this study because of data limitations. The bias-corrected SSEBop rates therefore could be affected in areas where seasonal changes in water levels are such that these would merit the reclassification of water-table conditions. 


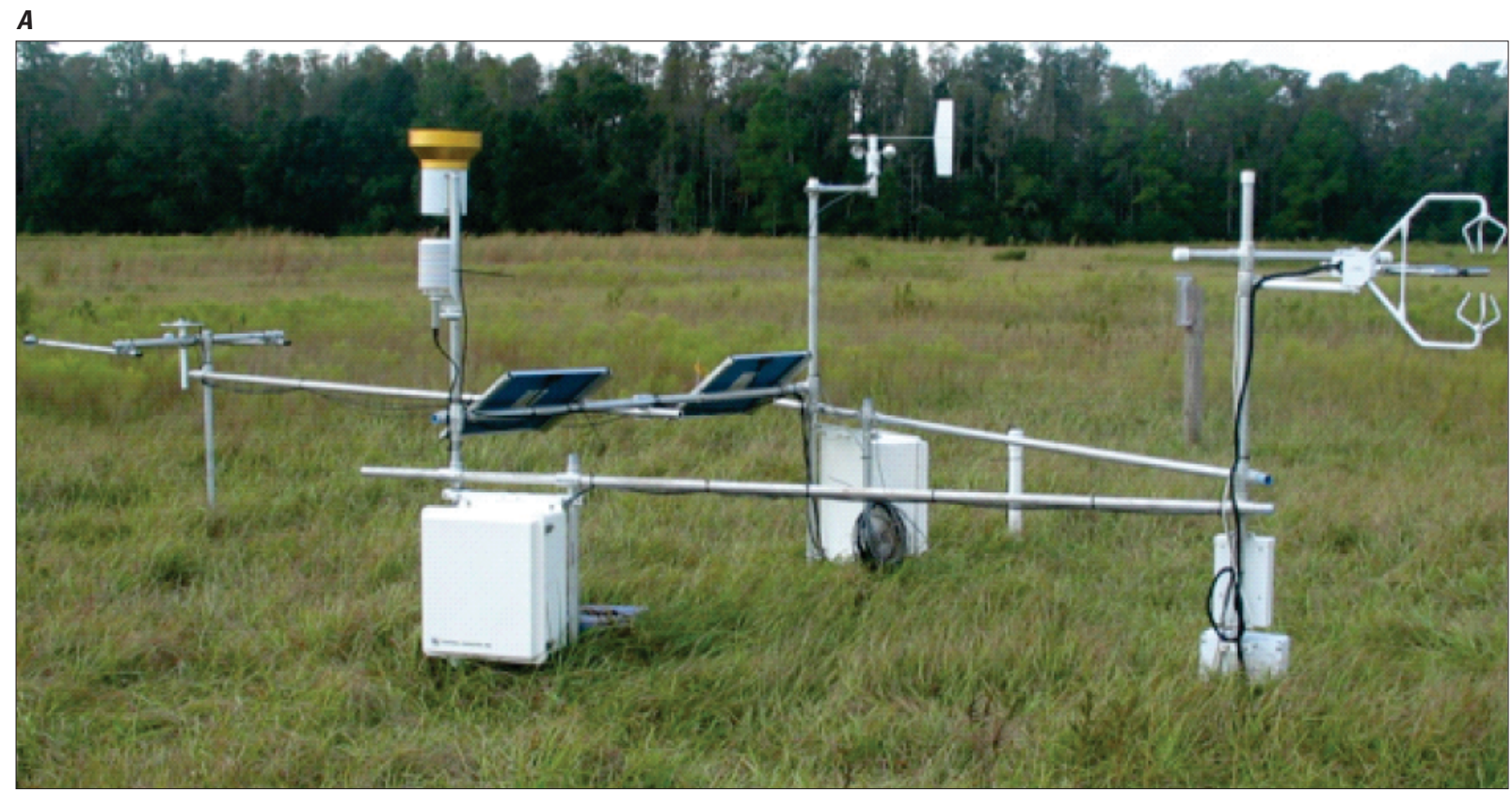

$\boldsymbol{B}$

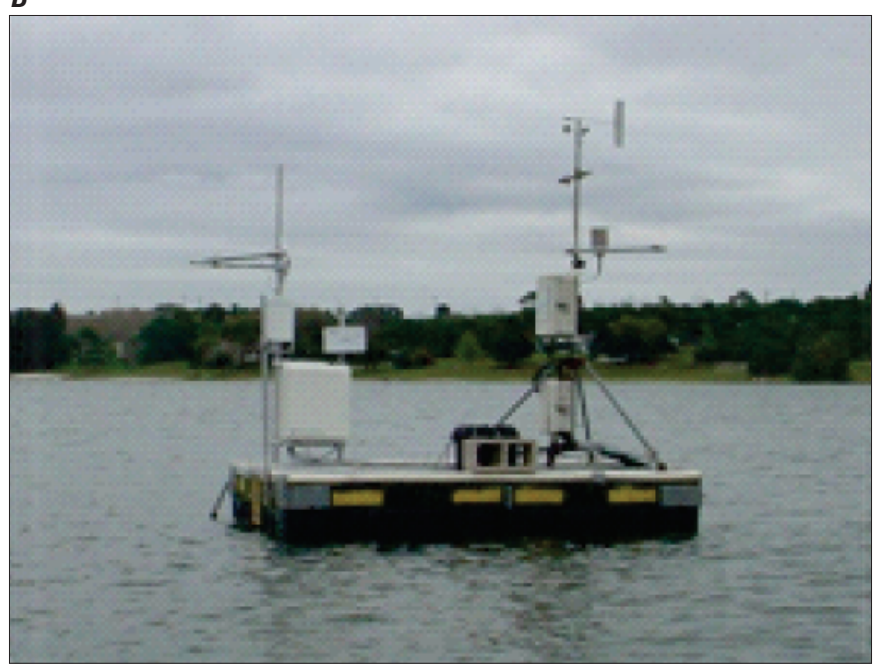

C

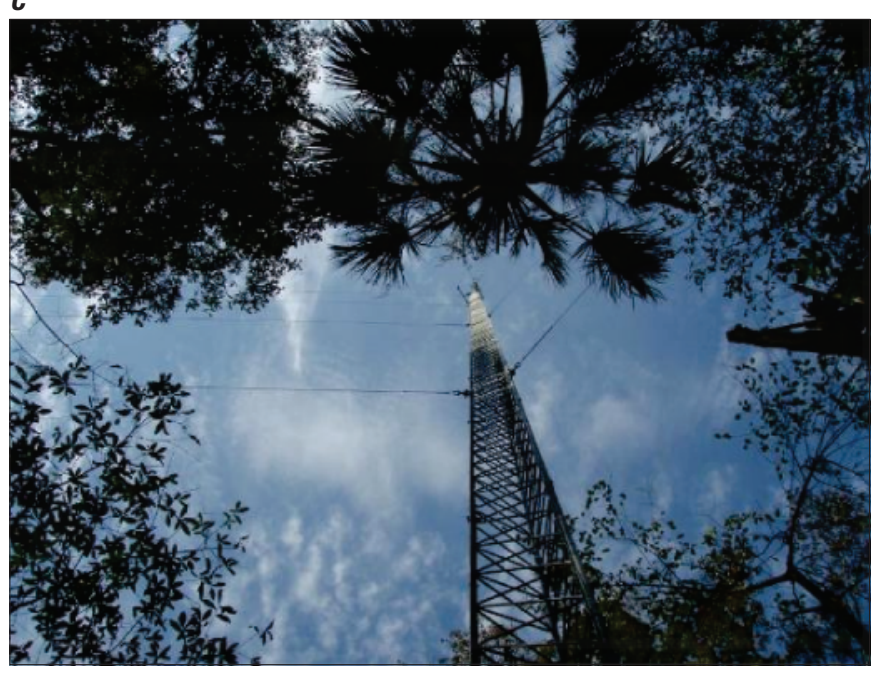

Figure 6. Instrumentation used to record data required to compute actual evapotranspiration at MEF stations located in, $A$, pasture with shallow depth to water of generally 5 feet or less (Starkey Pasture site), $B$, open-water surface (Lake Starr), and $C$, forested wetland with high canopy density (Dead River Forest site). Photographs by Amy Swancar, USGS.

\section{Computing Bias in SSEBop ETa}

Monthly mean bias in SSEBop rates was determined for each generalized land-use type and from regressions between the differences mETa rates minus SSEBop rates and SSEBop rates for the period of record of the MEF stations. The regressors were applied to each generalized land-use type and for the 2000-17 period of record of SSEBop rates. Bias correction for the appropriate land-use type does not imply the total elimination of bias in the SSEBop rates because additional bias may be associated with seasons or dry and wet periods. Bias corrections were applied to SSEBop rates at each 1-km-resolution grid point for the study area, except where SSEBop rates were identified as outliers. In general, outliers were points with low annual ETa rates (less than $5 \mathrm{in} / \mathrm{yr}$ ) and were replaced by luETa estimates at the grid point.

The method for correcting bias in SSEBop rates was based on regressions between mETa rates and uncorrected SSEBop rates $\left(\mathrm{SSEBop}_{\mathrm{u}}\right)$. Bias-corrected SSEBop rates are hereinafter denoted as SSEBop rates (no subscript). Leastsquares linear regression was used to calculate the slope $m$ and intercept $b$ (eq. 1) for the land-use types of agriculture, forest, forested wetland (including low and medium vegetation canopy density and high vegetation canopy density), marsh, 


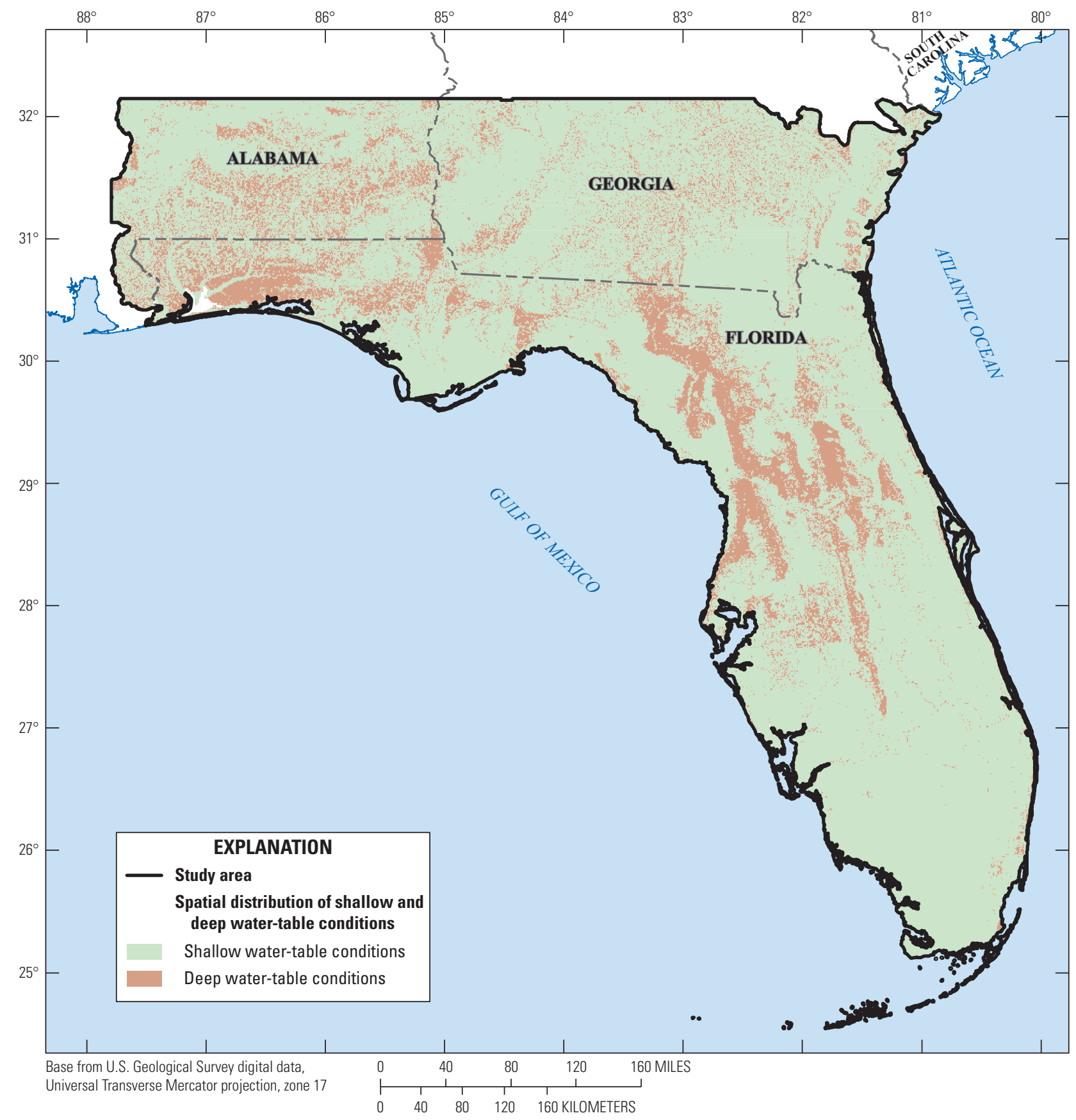

Figure 7. Spatial distribution of shallow and deep water-table conditions in Florida and parts of Alabama and Georgia.

pasture (including shallow and deep water-table conditions), and urban. Bias-corrected SSEBop rates were calculated from regression of the general linear model

$$
\mathrm{mETa}=m \cdot \operatorname{SSEBop}_{\mathrm{u}}+b
$$

and subsequently replacing mETa with SSEBop for the given land-use type:

$$
\text { SSEBop }=m \cdot \text { SSEBop }_{\mathrm{u}}+b .
$$

Bias is calculated from equation 1 by subtracting SSEBop $_{u}$ from both sides of the equation:

$$
\text { mETa }-\operatorname{SSEBop}_{u}=(m-1) \cdot \operatorname{SSEBop}_{u}+b .
$$

Monthly and annual mETa rates at the MEF stations had the largest range of values for the generalized land-use type of open-water surfaces. The application of a power function for open-water surfaces was chosen to reduce the largest possible predicted residuals between monthly mETa rates and SSEBop $\mathrm{p}_{\mathrm{u}}$ rates because the power function curve plots below the 
regressed line for large SSEBop uates (fig. 8). Bias-corrected SSEBop rates for the land-use type of open-water surface were computed by using a power function:

$$
\mathrm{mETa}=b \cdot \operatorname{SSEBop}_{\mathrm{u}}{ }^{m},
$$

where $m$ and $b$ in this case are slope and intercept of a loglinear model, respectively:

$$
\log (\mathrm{mETa})=m \cdot \log \left(\operatorname{SSEBop}_{\mathrm{u}}\right)+\log (b) .
$$

Equation 4 can also be used to estimate SSEBop, which is then computed for open-water surfaces as

$$
\text { SSEBop }=b \cdot \operatorname{SSEBop}_{\mathrm{u}}{ }^{m} .
$$

Bias is computed as

$$
\text { mETa }-\operatorname{SSEBop}_{u}=\left(b \cdot \operatorname{SSEBop}_{u}{ }^{m}\right)-\operatorname{SSEBop}_{u}
$$

or alternately as

$$
\mathrm{mETa}-\operatorname{SSEBop}_{\mathrm{u}}=\operatorname{SSEBop}_{\mathrm{u}} \cdot\left[\left(b \cdot \operatorname{SSEBop}_{\mathrm{u}}{ }^{m-1}\right)-1\right] .
$$

Monthly residuals are computed as mETa minus the biascorrected SSEBop rate and represent the remaining "scatter" once bias correction has been applied. Similarly, the term residual is used for evaluation of SSEBop based on that waterbalance method and is computed as the wbETa rate minus the bias-corrected SSEBop rate. Residuals were not computed for the luETa model.

A power function (eq. 6) was used to reduce bias in SSEBop $_{u}$ rates for open-water surfaces by decreasing the maximum bias-corrected SSEBop rate. When a linear model (eq. 2, fig. 8) was used to calculate the bias-corrected SSEBop rate for open-water surfaces, annual ETa rates were as high as $92 \mathrm{in} / \mathrm{yr}$, whereas the power-function regression reduced the highest estimated SSEBop ETa rate to $76.7 \mathrm{in} / \mathrm{yr}$. The lower SSEBop ETa rate of $76.7 \mathrm{in} / \mathrm{yr}$ was close to the maximum annual mETa at open-water stations of $74.26 \mathrm{in} / \mathrm{yr}$ in 2016 for the Lake Okeechobee MEF station (no. 11, fig. 1, table 1). The maximum monthly SSEBop $\mathrm{u}_{\mathrm{u}}$ rate at grid points at MEF station locations was $5.95 \mathrm{in} / \mathrm{mo}$ (fig. 8). The application of this monthly SSEBop rate to equation 6 gives an SSEBop of about $6.60 \mathrm{in} / \mathrm{mo}$, which is greater than the average of the $\mathrm{mETa}$ rates during the summer months at the open-water surface MEF stations (6.33 in/mo). A power function results in lower bias-corrected SSEBop rates compared to a linear model when SSEBop $\mathrm{p}_{\mathrm{u}}$ rates exceed about $3.5 \mathrm{in} / \mathrm{mo}$ (fig. 8). Computation of bias for a power function is based on logtransformed data applied to linear regression.

\section{Land-Use Type Data Sources}

Land-use type datasets were available from several sources (table 3). Land-use data for Florida for the 2000-17 period were compiled from the Florida Geographic Data Library (FGDL, 2011; https://www.fgdl.org/metadataexplorer/ explorer.jsp) for areas outside the Southwest Florida Water Management District (SWFWMD) and from the SWFWMD Open Data Portal (SWFWMD, 2019; https://data-swfwmd. opendata.arcgis.com/) for areas inside SWFWMD. Land-use surveys in parts of Alabama and Georgia were compiled from the National Land Cover Database (https://www.usgs.gov/ centers/eros/science/national-land-cover-database). Because annual land-use surveys from the FGDL and SWFWMD Open Data Portal were not available for each water management district (WMD), some surveys from previous years were used for the following years for some WMDs (table 3). Based on these land-use datasets, generalized land-use types were established for years or intervals of years as shown in table 3 . When more than one land-use survey was available for a WMD for one of these annual intervals, the most recent land-use survey was used. When no land-use survey was available for a WMD for one of these annual intervals, the previously available land-use survey was used.

The generalized land-use type assigned to each grid cell was the land-use type with the largest area within the given cell. The 2006 spatial distribution of the land-use types for the study area covers about 93,500 square miles $\left(\mathrm{mi}^{2}\right)$, and forest

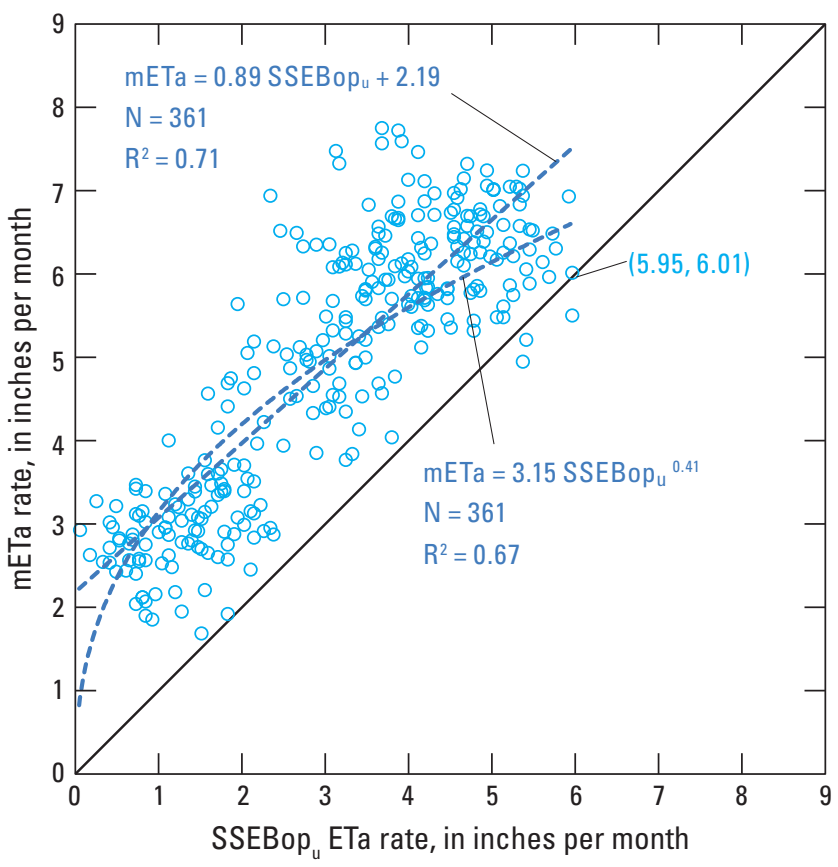

Figure 8. Monthly uncorrected Operational Simplified Surface Energy Balance (SSEBop ${ }_{\mathrm{u}}$ ) evapotranspiration (ET) rates versus actual evapotranspiration rates measured at four micrometeorological stations (mETa) located in the generalized land-use type of open-water surface, 2000-17. [N, number of measurements; $R^{2}$, coefficient of determination] 
Table 3. Year and source of land-use type datasets from water management districts' data portals used for each simulation year, 2000-17.

[FGDL, Florida Geographic Data Library Portal (2011); SWF GIS, Southwest Florida Water Management District Geospatial Data Portal (2019)]

\begin{tabular}{|c|c|c|c|c|c|}
\hline \multirow{2}{*}{$\begin{array}{c}\text { Simulation } \\
\text { year }\end{array}$} & \multicolumn{5}{|c|}{ Year and source by water management district } \\
\hline & Northwest Florida & Suwannee River & St. Johns River & Southwest Florida & South Florida \\
\hline 2000 & 1995 FGDL & 1995 FGDL & 2000 FGDL & 1999 SWF GIS & 1999 FGDL \\
\hline 2001 & 1995 FGDL & 1995 FGDL & 2000 FGDL & 1999 SWF GIS & 1999 FGDL \\
\hline 2002 & 1995 FGDL & 1995 FGDL & 2000 FGDL & 1999 SWF GIS & 1999 FGDL \\
\hline 2003 & 1995 FGDL & 1995 FGDL & 2000 FGDL & 1999 SWF GIS & 1999 FGDL \\
\hline 2004 & 2004 FGDL & 2004 FGDL & 2004 FGDL & 2004 SWF GIS & 2004 FGDL \\
\hline 2005 & 2004 FGDL & 2004 FGDL & 2004 FGDL & 2005 SWF GIS & 2004 FGDL \\
\hline 2006 & 2004 FGDL & 2004 FGDL & 2004 FGDL & 2006 SWF GIS & 2004 FGDL \\
\hline 2007 & 2007 FGDL & 2004 FGDL & 2004 FGDL & 2007 SWF GIS & 2004 FGDL \\
\hline 2008 & 2007 FGDL & 2008 FGDL & 2004 FGDL & 2008 SWF GIS & 2008 FGDL \\
\hline 2009 & 2007 FGDL & 2008 FGDL & 2009 FGDL & 2009 SWF GIS & 2008 FGDL \\
\hline 2010 & 2010 FGDL & 2008 FGDL & 2009 FGDL & 2010 SWF GIS & 2008 FGDL \\
\hline 2011 & 2010 FGDL & 2011 FGDL & 2009 FGDL & 2011 SWF GIS & 2008 FGDL \\
\hline 2012 & 2010 FGDL & 2011 FGDL & 2009 FGDL & 2011 SWF GIS & 2008 FGDL \\
\hline 2013 & 2013 FGDL & 2013 FGDL & 2013 FGDL & 2011 SWF GIS & 2013 FGDL \\
\hline 2014 & 2013 FGDL & 2014 FGDL & 2014 FGDL & 2014 SWF GIS & 2013 FGDL \\
\hline 2015 & 2013 FGDL & 2014 FGDL & 2014 FGDL & 2014 SWF GIS & 2013 FGDL \\
\hline 2016 & 2016 FGDL & 2014 FGDL & 2014 FGDL & 2014 SWF GIS & 2016 FGDL \\
\hline 2017 & 2016 FGDL & 2017 FGDL & 2014 FGDL & 2017 SWF GIS & 2016 FGDL \\
\hline
\end{tabular}

was the most prevalent land use (about 34 percent), extending over large areas in southern Georgia, southern Alabama, and northern Florida (table 4, fig. 5). Agriculture, forested wetland with low to medium canopy density, and shallow-water-table pasture each covered more than 10 percent of the study area. A noticeable trend in land use over the study period of 2000-17 is the upward trend in urban areas, from 7.16 percent for 2000-03 to 9.95 percent for 2017 (table 4). During 2000-17, pasture (shallow and deep water-table conditions) and forested areas decreased by about 1-2 percent. The upward trend in urban areas over the 2000-17 period adds model uncertainty because only one MEF station was in an urban area (station 21, fig. 1). Additional urban stations would improve estimates of ETa for this land use. Percentages of impervious areas in urban cells increase with population density and development; increases of impervious areas in urban cells generally cause ETa rates to decrease.

Land-use surveys for Florida use the Florida Land Use and Cover Classification System (FLUCCS) codes (FGDL, 2011). These FLUCCS codes were grouped by generalized land-use types with the goal of similar ET responses for each land-use type. The local land-use type for meteorological stations as identified in the field (tables 1 and 5) was compared with the land-use type specified in the land-use surveys to ensure consistency.
Mining was the only land-use type for which there were no available MEF station data. This land-use type, occurring in 0.78 percent of the study area (fig. 5), was assigned the slope $m$ and intercept $b$ regressors aimed at minimizing the differences between SSEBop and wbETa rates for basins 48-50 (fig. 2), which had the greatest number of mining cells. Monthly crop-coefficient ratios for the mining land-use type were assigned based on a linear combination of monthly crop-coefficient ratios for the shallow-water-table pasture and open-water surface land-use types in order to minimize the differences between luETa and wbETa rates for basins $48-50$.

\section{Actual ET Calculated with Generalized Land-Use Model}

Monthly reference evapotranspiration ETo rates from the GOES gridded dataset for Florida (Mecikalski and others, 2018; USGS, 2018a) and monthly mETa rates from the MEF stations were used to calculate monthly crop-coefficient ratios ( $\mathrm{mETa} / \mathrm{ETo})$ for each generalized land-use type. The largest crop-coefficient ratios were for open-water surfaces for all months, and the smallest ratios were for deep-water-table pasture (all months except July and September) and urban (July and September) (fig. 9). The crop-coefficient ratios for shallow-water-table pasture were higher than those for 
Table 4. Percentage of total study area of each generalized land-use type for each group of years for which land-use surveys were available in the 2000-17 period, and total area of each generalized land-use type for the same group of years.

[Abbreviations for land-use types are AGRIC, agriculture; FORES, forest; FORW1, forested wetland with low to medium canopy density; FORW2, forested wetland with high canopy density; MININ, mining; PASDW, pasture under deep water-table conditions; PASSW, pasture under shallow water-table conditions; WATER, open-water surface]

\begin{tabular}{|c|c|c|c|c|c|c|c|c|c|c|}
\hline Year & AGRIC & FORES & FORW1 & FORW2 & MARSH & MININ & PASDW & PASSW & URBAN & WATER \\
\hline \multicolumn{11}{|c|}{ Percentage of total study area } \\
\hline 2000-2003 & 11.20 & 36.24 & 11.75 & 3.11 & 6.47 & 0.66 & 4.11 & 16.18 & 7.16 & 3.12 \\
\hline 2004-2005 & 11.85 & 34.59 & 11.76 & 3.92 & 7.22 & 0.80 & 3.64 & 14.32 & 8.71 & 3.18 \\
\hline 2006 & 11.75 & 34.53 & 11.76 & 3.92 & 7.23 & 0.78 & 3.64 & 14.34 & 8.85 & 3.20 \\
\hline 2007 & 11.76 & 34.70 & 11.79 & 3.81 & 7.33 & 0.76 & 3.54 & 14.17 & 8.97 & 3.17 \\
\hline 2008-2009 & 14.05 & 34.78 & 11.15 & 3.79 & 5.39 & 0.75 & 3.44 & 14.10 & 9.43 & 3.13 \\
\hline 2010 & 13.91 & 34.82 & 11.15 & 3.78 & 5.35 & 0.74 & 3.47 & 14.14 & 9.51 & 3.14 \\
\hline 2011-2012 & 13.77 & 34.61 & 11.10 & 3.74 & 5.45 & 0.74 & 3.55 & 14.29 & 9.62 & 3.12 \\
\hline 2013 & 11.10 & 34.41 & 11.90 & 2.98 & 7.21 & 0.74 & 3.59 & 15.06 & 9.84 & 3.17 \\
\hline 2014-2016 & 11.10 & 34.57 & 11.82 & 3.03 & 7.26 & 0.76 & 3.32 & 14.92 & 10.05 & 3.16 \\
\hline 2017 & 11.22 & 34.50 & 12.02 & 3.51 & 7.16 & 0.78 & 3.42 & 14.24 & 9.95 & 3.19 \\
\hline \multicolumn{11}{|c|}{ Number of square miles in the study area } \\
\hline $2000-2003$ & $10,465.5$ & $33,870.2$ & $10,977.7$ & $2,903.4$ & $6,048.9$ & 620.6 & $3,844.2$ & $15,120.2$ & $6,693.9$ & $2,919.5$ \\
\hline 2004-2005 & $11,078.9$ & $32,332.6$ & $10,992.5$ & $3,663.3$ & $6,746.9$ & 748.5 & $3,405.9$ & $13,388.1$ & $8,138.4$ & $2,969.1$ \\
\hline 2006 & $10,979.8$ & $32,285.8$ & $10,990.5$ & $3,662.6$ & $6,759.3$ & 726.5 & $3,399.1$ & $13,400.5$ & $8,271.5$ & $2,988.7$ \\
\hline 2007 & $10,995.6$ & $32,428.2$ & $11,018.3$ & $3,563.8$ & $6,847.0$ & 707.3 & $3,313.1$ & $13,239.5$ & $8,386.7$ & $2,964.6$ \\
\hline 2008-2009 & $13,132.5$ & $32,503.2$ & $10,420.8$ & $3,539.4$ & $5,037.2$ & 697.6 & $3,217.4$ & $13,174.5$ & $8,815.7$ & $2,925.7$ \\
\hline 2010 & $13,002.9$ & $32,545.8$ & $10,419.8$ & $3,529.1$ & $4,995.9$ & 689.4 & $3,246.7$ & $13,215.4$ & $8,884.8$ & $2,934.3$ \\
\hline 2011-2012 & $12,873.2$ & $32,347.0$ & $10,376.4$ & $3,499.2$ & $5,090.5$ & 690.8 & $3,319.9$ & $13,354.1$ & $8,994.6$ & $2,918.5$ \\
\hline 2013 & $10,376.1$ & $32,159.5$ & $11,122.2$ & $2,786.7$ & $6,737.2$ & 694.9 & $3,351.2$ & $14,073.7$ & $9,200.6$ & $2,961.8$ \\
\hline 2014-2016 & $10,369.9$ & $32,311.6$ & $11,051.7$ & $2,828.0$ & $6,789.2$ & 712.4 & $3,105.6$ & $13,946.8$ & $9,392.2$ & $2,956.7$ \\
\hline 2017 & $10,488.9$ & $32,249.7$ & $11,235.7$ & $3,277.3$ & $6,693.9$ & 728.6 & $3,200.2$ & $13,308.3$ & $9,300.4$ & $2,981.1$ \\
\hline
\end{tabular}


Table 5. Florida Land Use and Cover Classification System (FLUCCS) codes used to assign generalized land-use types.

[FLUCCS, hierarchical numerical code that follows the Florida Land Use and Cover Classification System, listed as ranges of codes (Florida Geographic Data Library, 2011); HCD, high canopy density; LMCD; low to medium canopy density]

\begin{tabular}{ll}
\hline \multicolumn{1}{c}{ FLUCCS codes } & \multicolumn{1}{c}{ Generalized land-use type } \\
\hline $1800 ; 1820 ; 2140-2150 ; 2156-2230 ; 2300-2500 ; 2520 ; 2590$ & Agriculture \\
$4100-4300 ; 4310-4430 ; 6180-6182$ & Forest \\
$6100 ; 6130 ; 6160-6170 ; 6190-6191 ; 6300$ & Forested wetland HCD \\
$6120 ; 6140-6150 ; 6171 ; 6200-6260$ & Forested wetland LMCD \\
$5250 ; 6110-6111 ; 6310-6540$ & Marsh \\
$1530-1533 ; 1600-1633 ; 1650 ; 1670 ; 2540-2550 ; 7400 ; 7420$ & Mining \\
$1660 ; 1810 ; 1840 ; 5100-5240 ; 5300-5720 ; 7100 ; 7440 ; 7470 ; 8160 ; 8360$ & Open-water surface \\
$1900-1910 ; 1930-2130 ; 2153 ; 2240 ; 2510 ; 2600-3300 ; 4301 ; 6172 ; 7200 ; 7410 ; 7450 ; 7500 ; 8350 ;$ & Pasture \\
9990 & \\
$1100-1523 ; 1540-1590 ; 1640 ; 1700-1790 ; 1830-1833 ; 1850-1890 ; 1920 ; 2530 ; 6600 ; 7300 ; 7430 ;$ & Urban \\
$8100-8150 ; 8170-8340 ; 8370 ; 8390$ & \\
\hline
\end{tabular}

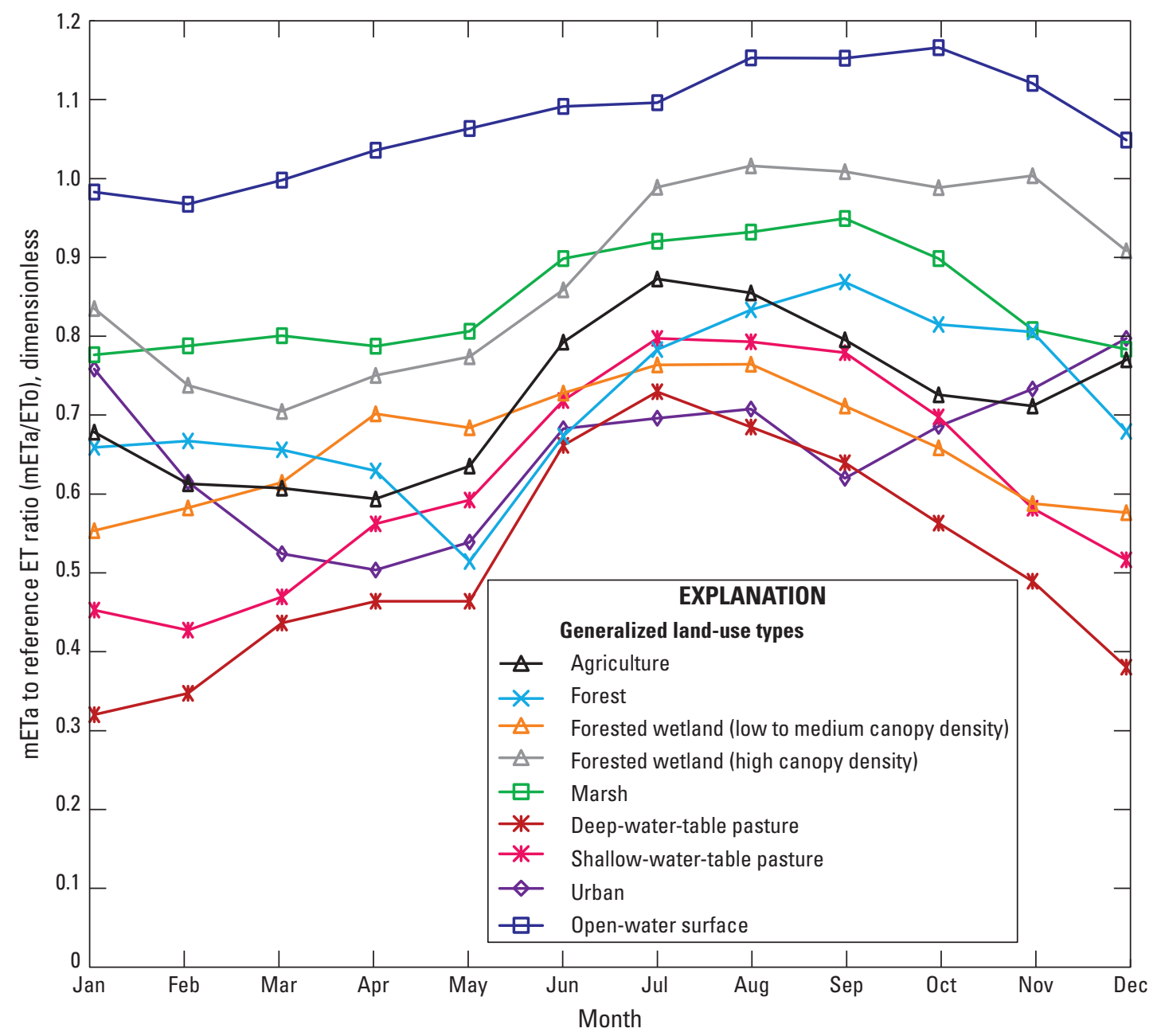

Figure 9. Average monthly ratios of actual evapotranspiration rates computed by using micrometeorological station data ( $\mathrm{mETa}$ ) to reference evapotranspiration (ETo) rates for generalized land-use types. 
deep-water-table pasture, and the ratios for forested wetland with high canopy density were higher than those for forested wetland with low to medium canopy density, supporting the need to further differentiate the types of pasture and forested wetland because of their distinctive responses to ETa rates.

Grid points in the GOES ETo dataset were assigned generalized land-use types, and crop coefficients for the assigned land uses were multiplied by the GOES ETo rate to estimate ETa rates at a 2-km grid spacing for Florida (luETa). In this report, luETa rates were used to replace anomalous SSEBop rates that were $0 \mathrm{in} / \mathrm{mo}$ or less than $5 \mathrm{in} / \mathrm{yr}$ and anomalous when compared to surrounding points, which were located near coastal areas and were inconsistent with surrounding cells under the same land-use type located further inland. The number of anomalous SSEBop annual rates in the 1-squarekilometer grid ranged from 4,680 cells (1.72 percent) in 2005 to 12,429 cells (4.57 percent) in 2017 . Anomalous SSEBop rates that were replaced with luETa rates were not further bias corrected.

\section{Actual ET Calculated with Water-Balance Method}

A water-balance method was used to compute annual actual evapotranspiration (wbETa) for 55 basins (fig. 2, table 2) for the $2000-17$ period. The water-balance method includes the following inflows and outflows: (1) rainfall; (2) measured streamflows at the outlet and, where applicable, the inlet of each basin (NetQ); (3) estimated springflows (Sp), where applicable; (4) water levels at wells and stages at lakes to estimate changes in groundwater storage; (5) estimated groundwater leakage rates leaving or entering the basin; and (6) estimated irrigation rates (Irrig) (fig. 10). The irrigation rates were obtained from Marella (2004, 2009, 2014, 2020).

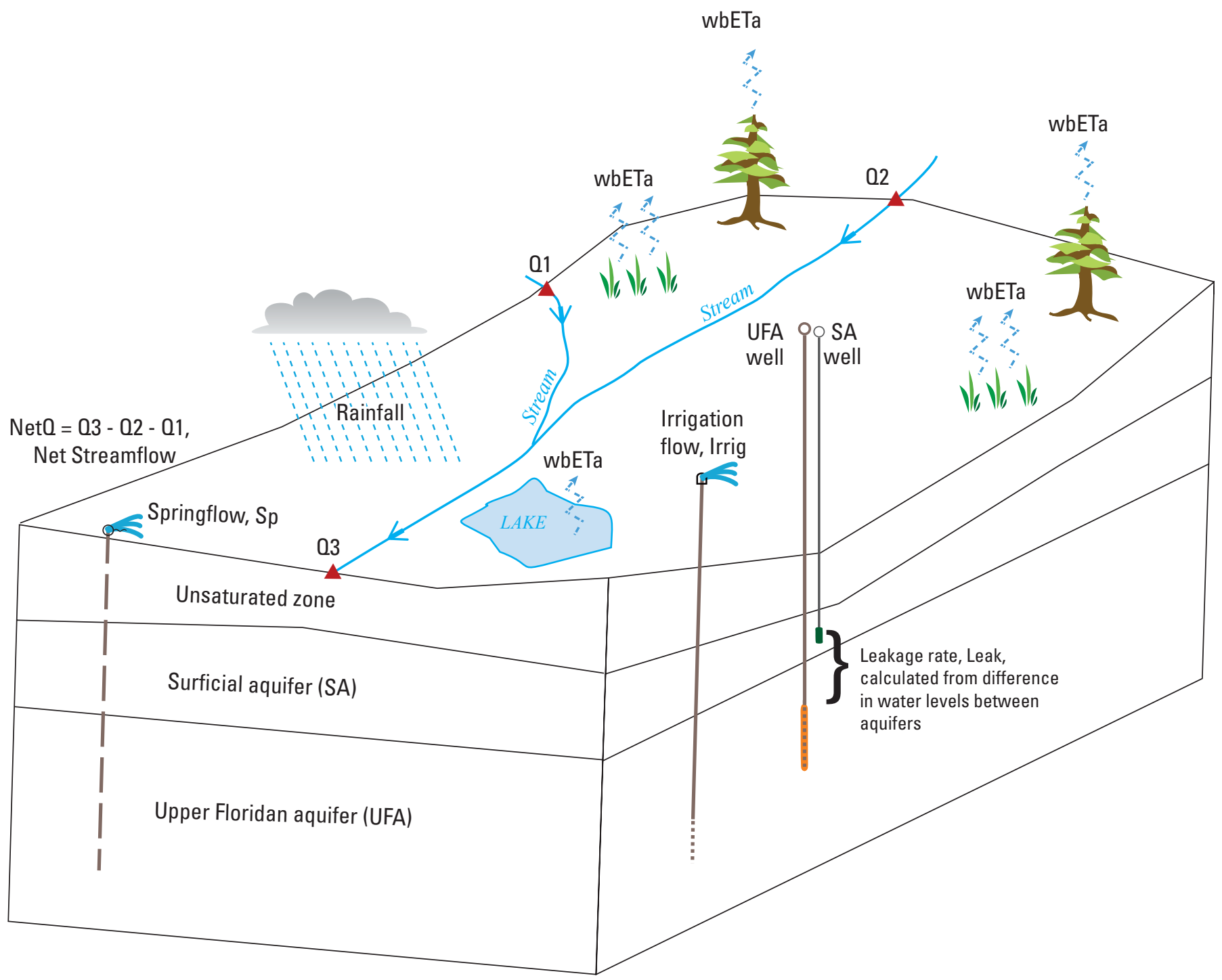

Figure 10. General inflows and outflows used in the water-balance method applied to a basin. [Net0, net streamflow change in the basin; 01, 02, inflowing streamflows at indicated locations; 03, outflowing stream; wbETa, water-balance method estimate of actual evapotranspiration] 
The 55 basins that were modeled span most of the study area and range in area from $4.7 \mathrm{mi}^{2}$ for the Eau Gallie River basin (number 28, fig. 2, table 2) to $9,533 \mathrm{mi}^{2}$ for the Suwannee River basin (number 34, including subbasins 30-33; fig. 2, table 2). The average basin area for all 55 basins is about $800 \mathrm{mi}^{2}$ (table 2). The water-balance method was applied to the control volume for the basins, which varied based on the aquifers included in calculations (fig. 10). The control volume for basins 1-2, 4-29, and 36-55 (fig. 2) was assumed to extend from the top of the vegetation canopy to the bottom of the surficial aquifer. The control volume for basins 3 and 30-35 was assumed to extend from the top of the vegetation canopy to the bottom of the Upper Floridan aquifer; therefore, springflow from the aquifer does not need to be estimated for these basins. The Upper Floridan aquifer is unconfined in some parts of basins 3 and 30-35 and thus was included in the control volume.

Annual wbETa rates calculated by using the waterbalance method for each basin were compared with the annual average SSEBop rates calculated as the average of all SSEBop $1-\mathrm{km}$ grid cells within the basin for the given year. Inherent sources of error are associated with the water-balance method. The estimation of flow measurement errors in the waterbalance method, whether spring, stream, or leakage flow, is beyond the scope of this study. Errors in streamflow, rainfall rates, changes in basin storage, leakage rates, and irrigation rates could interact with each other to produce a range of estimated errors. Additional sources of error include the use of estimated fluxes where measured rates were not available, inconsistencies between surface-water and groundwater contributing areas, basin-delineation uncertainties in areas with low topographic relief, limited water-level data for estimating basin storage changes, and the underrepresentation of the spatial variability of fluxes within a basin.

\section{Water-Balance Validation Data}

The Parameter-Elevation Regressions on Independent Slopes Model (PRISM; Daly and others, 2008) was used as the source of monthly rainfall data in the water-balance method. The PRISM dataset has a spatial resolution of 2.5 arc minutes (about $4 \mathrm{~km}$ ) for the conterminous United States. Gridded monthly data from PRISM were averaged over each basin by using the USGS Geo Data Portal web application (USGS, 2020). ArcGIS polygon shapefiles representing the extent of each basin were uploaded to the USGS Geo Data Portal, which then used the basin shapefiles and PRISM data to extract and compute monthly rainfall rates for selected basins. The monthly rainfall data tabulated for basins in the study area are available in a related data release (Sepúlveda, 2021).

Irrigation flow rates were applied only to basins that did not include the Upper Floridan aquifer in the control volume and were assumed to be 50 percent of the water-use rates compiled by Marella $(2004,2009,2014,2020)$ because of potential surface runoff and irrigation deficiencies. Groundwater withdrawals were assumed to be the source of irrigation flows. Annual rates of groundwater withdrawals were calculated from water-use estimates for 2004, 2009, 2014, and 2020. Irrigation rates for years with records were applied to preceding years that lacked irrigation data. For example, rates from 2014 were applied to 2010-13, and rates from 2020 were applied to 2015-17. Irrigation rates were compiled by Marella $(2004,2009,2014,2020)$ by county. Average irrigation rates for each basin were averaged by using the area and rate of each county inside the basin. Irrigation rates and springflows, generally available in cubic feet per second, were converted to linear fluxes, in inches per year, by adjusting for basin area (table 2).

Streamflow data were obtained from the USGS National Water Information System (NWIS) (USGS, 2018b) and used to calculate the net flow leaving each basin. Flows from Upper Floridan aquifer springs ( $\mathrm{Sp}$ in fig. 10) were approximated by using averaged measurements from NWIS for the springflow gages listed in table 6 (USGS, 2018b). Springflows for some periods of record were approximated from other periods of record based on data availability. The daily, monthly, and annual net flows leaving the basin and the springflows for the applicable basins are in Sepúlveda (2021).

\section{Basin Inflows and Outflows}

Inflows to a basin (positive fluxes) generally included rainfall, irrigation flow from wells open to the Upper Floridan aquifer and flows from Upper Floridan aquifer springs. Outflows from a basin (negative fluxes) generally included streamflows and downward leakage rates to the Upper Floridan aquifer. Where applicable, leakage rates from the Upper Floridan aquifer to the surficial are considered inflows to a basin. The net streamflow leaving the basin (NetQ in fig. 10) was calculated by using data from NWIS (USGS, 2018b) for the streamgages at the basin outlets and inlets (table 2). Leakage rates (Leak in fig. 10) between the surficial aquifer and the Upper Floridan aquifer for basins in the St. Johns River Water Management District (SJRWMD) were calculated from recharge rate maps of the Upper Floridan aquifer for 2000, 2005, and 2015 (SJRWMD, 2016). Leakage rates between the surficial aquifer and the Upper Floridan aquifer for basins in Northwest Florida Water Management District (NWFWMD), SWFWMD, Tampa Bay Water (TBW), and basins 6 and 9 in South Florida Water Management District (SFWMD) (fig. 2) were estimated from the product of vertical leakance obtained from Sepúlveda (2002) and annual differences in water-level data from each pair of wells (tables 7, 8, and 9) that are near each other and tap these aquifers. Leakage rates for basins 7, 8, and 10 in SFWMD were calculated from simulated vertical flows that were calculated from SFWMD groundwater-flow models (Y. Assegid, South Florida Water Management District, written commun., 2019). Leakage rates between the Lower and Upper Floridan aquifers were not modeled; if leakage between these two aquifers is determined 
Table 6. Upper Floridan aquifer springs, USGS National Water Information System station identification, and basin number where spring is located.

[USGS, U.S. Geological Survey; Station no., National Water Information System (USGS, 2018b) station identification number; Basin(s), location of spring (see table 2 and figure 2 for basin information and location)]

\begin{tabular}{|c|c|c|c|c|}
\hline Spring name & Station no. & Basin(s) & $\begin{array}{l}\text { Latitude (deci- } \\
\text { mal) }\end{array}$ & $\begin{array}{l}\text { Longitude } \\
\text { (decimal) }\end{array}$ \\
\hline Alexander Springs at Astor Discharge & 00291896 & 18 & 29.08130 & -81.57588 \\
\hline Ponce De Leon Springs at De Land Discharge & 00301897 & 18 & 29.13398 & -81.36288 \\
\hline Fern Hammock Springs at Ocala Discharge & 00311899 & 18 & 29.18359 & -81.70812 \\
\hline Juniper Springs at Ocala Discharge & 00321898 & 18 & 29.18494 & -81.71149 \\
\hline Rock Springs at Apopka Discharge & 00330830 & 18,24 & 28.75645 & -81.50174 \\
\hline Salt Springs near Eureka Discharge & 00341901 & 18 & 29.35027 & -81.73186 \\
\hline Silver Glen Springs at Astor Discharge & 00351900 & 18 & 29.24563 & -81.64328 \\
\hline Sweetwater Springs at Astor Discharge & 00361904 & 18 & 29.21899 & -81.65984 \\
\hline Wekiwa Springs at Altamonte Springs Discharge & 00371831 & 18,24 & 28.71189 & -81.46042 \\
\hline Gemini Springs at DeBary Discharge & 00410494 & 18 & 28.86254 & -81.31110 \\
\hline Miami Springs at Longwood Discharge & 00421834 & 18,24 & 28.71090 & -81.44264 \\
\hline Palm Springs at Longwood Discharge & 00441845 & 18,24 & 28.69119 & -81.39290 \\
\hline Sanlando Springs at Longwood Discharge & 00451840 & 18,24 & 28.68859 & -81.39607 \\
\hline Starbuck Springs at Longwood Discharge & 00471851 & 18,24 & 28.69686 & -81.39121 \\
\hline Blue Springs at Orange City Discharge & 00490362 & 18 & 28.94722 & -81.33972 \\
\hline Fenney Springs near Coleman & 02312664 & 45 & 28.79527 & -82.03842 \\
\hline Gum Springs near Holder & 02312764 & 46 & 28.95140 & -82.24980 \\
\hline Blue Springs at Yalaha Discharge & 10241178 & 16,18 & 28.74857 & -81.82755 \\
\hline Bugg Spring at Okahumpka Discharge & 10840068 & 16,18 & 28.75278 & -81.90139 \\
\hline Clifton Springs at Winter Springs Discharge & 10872794 & 18 & 28.69944 & -81.23722 \\
\hline Green Springs at Deltona Discharge & 10922661 & 18 & 28.86273 & -81.24753 \\
\hline Seminole Spring & 11631854 & 18 & 28.84262 & -81.52785 \\
\hline Messant Spring & 11641894 & 18 & 28.85617 & -81.49932 \\
\hline Holiday Springs Site 1 at Yalaha Discharge & 14402640 & 16,18 & 28.74000 & -81.81778 \\
\hline Wekiva Falls Resort & 14452659 & 18,24 & 28.79488 & -81.42069 \\
\hline Island Spring at Sanford Discharge & 15790431 & 18 & 28.82278 & -81.41750 \\
\hline Apopka Spring at Oakland Discharge & 15804854 & $15,16,18$ & 28.56695 & -81.68040 \\
\hline Beltons Millpond Spring Complex near Sumterville & 284530082034800 & 45 & 28.75861 & -82.06389 \\
\hline Blue Spring at Sumter County & 284709082024100 & 45 & 28.78583 & -82.04472 \\
\hline Wayne Lee Spring & 285133082053100 & 45 & 28.85906 & -82.09181 \\
\hline Henry Green Spring & 285207082054100 & 45 & 28.86887 & -82.09453 \\
\hline
\end{tabular}


Table 7. Surficial and Upper Floridan aquifer wells used to determine changes in basin storage and leakage rates in Northwest Florida Water Management District and South Florida Water Management District basins.

[Well name, name provided in data source; Data source, refers to either Northwest Florida Water Management District (NWFWMD) or DBHYDRO database; NWFWMD no., Northwest Florida Water Management District number provided in data source; Basin, location of well (see table 2 and figure 2 for basin information and location); Nest ID, matching numbers indicate wells used to calculate water-level differences between aquifers; SA, surficial aquifer; UFA, Upper Floridan aquifer; SA wells were used to calculate basin storage, including those with NEST ID equal to 0; MPZ, main producing zone; DBHYDRO, South Florida Water Management District 's corporate environmental database]

\begin{tabular}{|c|c|c|c|c|c|c|c|}
\hline Well name & Data source & $\begin{array}{l}\text { NWFWMD no. / } \\
\text { DBHYDRO key }\end{array}$ & Aquifer & $\begin{array}{c}\text { Latitude } \\
\text { (decimal degrees) }\end{array}$ & $\begin{array}{c}\text { Longitude } \\
\text { (decimal degrees) }\end{array}$ & Basin & Nest ID \\
\hline NWFWMD-HQ SA & NWFWMD & 3341 & SA & 30.51852 & -84.46363 & 1 & 1 \\
\hline $\begin{array}{l}\text { NWFWMD-HQ UFA } \\
\text { OBS/S704 }\end{array}$ & NWFWMD & 3340 & UFA & 30.51868 & -84.46353 & 1 & 1 \\
\hline $\begin{array}{l}\text { NWFWMD-Otter } \\
\text { Camp SA/S821 }\end{array}$ & NWFWMD & 968 & SA & 30.30862 & -84.61548 & 1 & 2 \\
\hline $\begin{array}{l}\text { NWFWMD-Otter } \\
\text { Camp UFA-SZ/S824 }\end{array}$ & NWFWMD & 965 & UFA & 30.30880 & -84.61555 & 1 & 2 \\
\hline $\begin{array}{l}\text { NWFWMD- } \\
\text { Blountstown SA }\end{array}$ & NWFWMD & 2626 & SA & 30.45018 & -85.07007 & 2 & 3 \\
\hline $\begin{array}{l}\text { NWFWMD- } \\
\text { Blountstown UFA }\end{array}$ & NWFWMD & 2624 & UFA & 30.45019 & -85.07024 & 2 & 3 \\
\hline $\begin{array}{l}\text { International Paper at } \\
\text { Cypress }\end{array}$ & NWFWMD & 4795 & UFA & 30.73586 & -85.10971 & 2 & 3 \\
\hline Bonifay \#2 & NWFWMD & 5033 & UFA & 30.78603 & -85.68533 & 3 & 0 \\
\hline $\begin{array}{l}\text { SWU-FAF \#47 } \\
\text { Monitor/S655 }\end{array}$ & NWFWMD & 3718 & UFA & 30.56309 & -86.02980 & 3 & 0 \\
\hline $\begin{array}{l}\text { RU Monitor/Cedar } \\
\text { Street/S672 }\end{array}$ & NWFWMD & 8361 & UFA & 30.64332 & -86.10923 & 3 & 0 \\
\hline $\begin{array}{l}\text { NWFWMD-Jackson } \\
\text { Still SA }\end{array}$ & NWFWMD & 5419 & SA & 30.89992 & -86.20703 & 4 & 4 \\
\hline $\begin{array}{l}\text { NWFWMD-Jackson } \\
\text { Still UFA }\end{array}$ & NWFWMD & 5417 & UFA & 30.89999 & -86.20702 & 4 & 4 \\
\hline $\begin{array}{l}\text { NWFWMD-Quintette } \\
\text { shallow zone }\end{array}$ & NWFWMD & 4478 & SA & 30.66488 & -87.29239 & 5 & 5 \\
\hline $\begin{array}{l}\text { NWFWMD- Quintette } \\
\text { deep MPZ }\end{array}$ & NWFWMD & 4476 & MPZ & 30.66485 & -87.29239 & 5 & 5 \\
\hline $\begin{array}{l}\text { NWFWMD-Oak } \\
\text { Grove shallow zone }\end{array}$ & NWFWMD & 5481 & SA & 30.92089 & -87.44288 & 5 & 6 \\
\hline $\begin{array}{l}\text { NWFWMD-Oak } \\
\text { Grove deep MPZ }\end{array}$ & NWFWMD & 5479 & MPZ & 30.92078 & -87.44290 & 5 & 6 \\
\hline Taft & DBHYDRO & 5038 & SA & 28.43612 & -81.37145 & 6 & 0 \\
\hline AIR19W1 & DBHYDRO & PT636 & SA & 28.40328 & -81.35378 & 6 & 0 \\
\hline ORS-1 & DBHYDRO & PT640 & SA & 28.44444 & -81.38500 & 6 & 7 \\
\hline Skylake & DBHYDRO & PT642 & UFA & 28.44444 & -81.38500 & 6 & 7 \\
\hline HES-22S & DBHYDRO & AI630 & SA & 26.67139 & -81.03333 & 7 & 0 \\
\hline HES-23S & DBHYDRO & AI629 & SA & 26.58639 & -81.12694 & 7 & 0 \\
\hline HES-26S & DBHYDRO & 90670 & SA & 26.44722 & -80.97917 & 7 & 0 \\
\hline HE-859 & DBHYDRO & 37384 & SA & 26.46063 & -81.07646 & 7 & 0 \\
\hline HE-0856 & DBHYDRO & 2406 & SA & 26.51007 & -81.12618 & 7 & 0 \\
\hline HE-555 & DBHYDRO & 2610 & SA & 26.64611 & -81.43500 & 8 & 0 \\
\hline HE-557 & DBHYDRO & 37383 & SA & 26.71000 & -81.51806 & 8 & 0 \\
\hline CRS02FM & DBHYDRO & L7465 & SA & 26.78861 & -81.23389 & 8 & 0 \\
\hline
\end{tabular}


Table 7. Surficial and Upper Floridan aquifer wells used to determine changes in basin storage and leakage rates in Northwest Florida Water Management District and South Florida Water Management District basins.—Continued

[Well name, name provided in data source; Data source, refers to either Northwest Florida Water Management District (NWFWMD) or DBHYDRO database; NWFWMD no., Northwest Florida Water Management District number provided in data source; Basin, location of well (see table 2 and figure 2 for basin information and location); Nest ID, matching numbers indicate wells used to calculate water-level differences between aquifers; SA, surficial aquifer; UFA, Upper Floridan aquifer; SA wells were used to calculate basin storage, including those with NEST ID equal to 0; MPZ, main producing zone; DBHYDRO, South Florida Water Management District 's corporate environmental database]

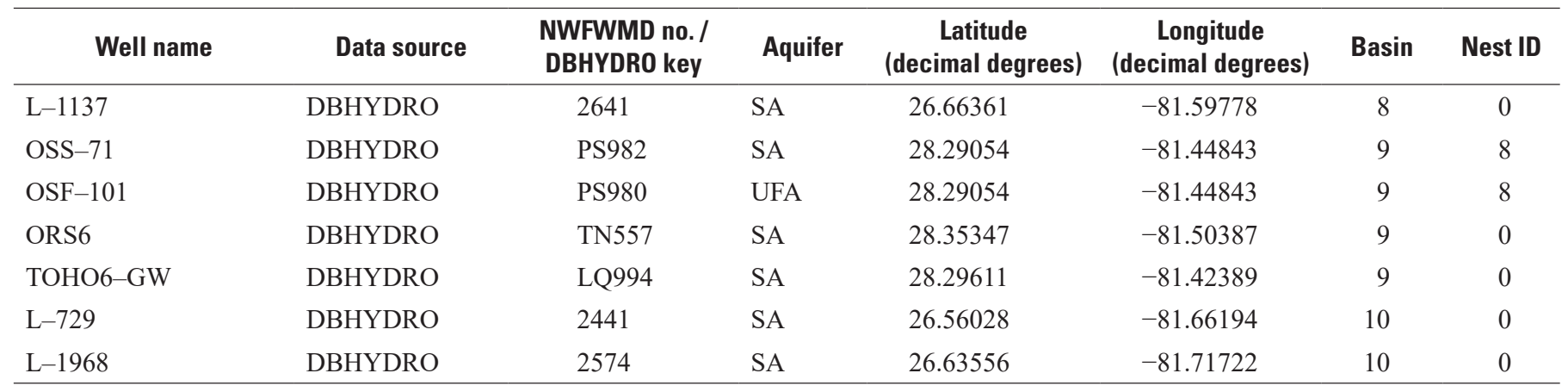

to be substantial, then the control volume used in the application of the water-balance method would have to include the entire Floridan aquifer system.

Changes in basin storage can be either positive or negative, and were calculated from

$$
\Delta S=S_{y} \cdot \Delta h
$$

where

$$
\begin{aligned}
& \Delta h \quad \text { is the water-level difference between the end } \\
& \text { and the beginning of the year at wells in } \\
& \text { the basin, and } \\
& S_{y} \quad \text { is the specific yield. }
\end{aligned}
$$

If water levels increased by the end of the year relative to the beginning of the year, the change in basin storage is positive. If water levels decreased by the end of the year, the change in basin storage is negative. In general, changes in basin storage were negative for years of relatively low rainfall such as 2000 and 2006 and were positive for years of relatively high rainfall such as 2004 and 2014. Most of the water-level data were referenced to North American Vertical Datum of 1988 (NAVD 88); however, only the temporal water-level differences were used to calculate changes in basin storage and leakance rates. A specific yield value of 0.2 was used as a one-significantdigit approximation from Sepúlveda and others (2018) to calculate changes in basin storage for sands in the surficial aquifer. Changes in basin storage for SJRWMD basins were calculated from only surficial aquifer wells because the Upper Floridan aquifer was not exposed at the surface in these basins (table 10), and changes in basin storage for the Suwannee River Water Management District (SRWMD) basins were calculated from only Upper Floridan aquifer wells because the surficial aquifer was not present in these basins (table 11).
The inclusion of the Upper Floridan aquifer as part of the control volume for a basin changed the variables used to estimate the change in basin storage (eq. 9). For basins 3 and 30-35 (fig. 2), where the control volume included the Upper Floridan aquifer, the water-level difference between the ending and the beginning of the year for these seven basins was calculated from Upper Floridan aquifer wells (tables 7 and 11). An average specific yield value of 0.15 was applied to areas where the Upper Floridan aquifer is unconfined (Sepúlveda, 2002).

The water-balance method (fig. 10) was applied using the equation

$$
\mathrm{wbETa}=\text { Rainfall }+ \text { Irrig }+\mathrm{Sp}-\mathrm{NetQ}-\Delta S-\text { Leak (10) }
$$

for basins 1, 2, 4-29, and 36-55 (fig. 2). The inflow and outflow data for each basin and the water-level data for each well are in Sepúlveda (2021). The inclusion of the Upper Floridan aquifer as part of the control volume, applied to basins 3 and $30-35$, reduces equation 10 to

$$
\text { wbETa }=\text { Rainfall }- \text { NetQ }-\Delta S,
$$

where variables Irrig, Leak, and Sp in equation 10 are not considered in equation 11 because these fluxes occur within the same control volume. Note that if the change in basin storage is negative in equations 10 or 11, then wbETa will increase; if the change in basin storage is positive, then wbETa will decrease.

Changes in basin storage for basins with large lakes and stage data $\left(h_{L_{i}}\right)$ for each lake $i$ were computed from

$$
\Delta S=\frac{1}{A} \sum_{i} A_{L_{i}} \Delta h_{L_{i}}+\frac{S_{y}}{A}\left(A-\sum_{i} A_{L_{i}}\right) \Delta h,
$$


Table 8. Surficial and Upper Floridan aquifer wells used to determine changes in basin storage and leakage rates in Southwest Florida Water Management District (SWFWMD) basins.

[Well name and well number, name and number of well provided in SWFWMD Data Portal; Basin(s), location of well (see table 2 and figure 2 for basin information and location); Nest ID, same number indicates wells used to calculate water-level differences between aquifers; SA, surficial aquifer; UFA, Upper Floridan aquifer; SA wells were used to calculate basin storage, including those with NEST ID equal to 0; SR, State Road; ROMP, Regional Observation Monitoring Program]

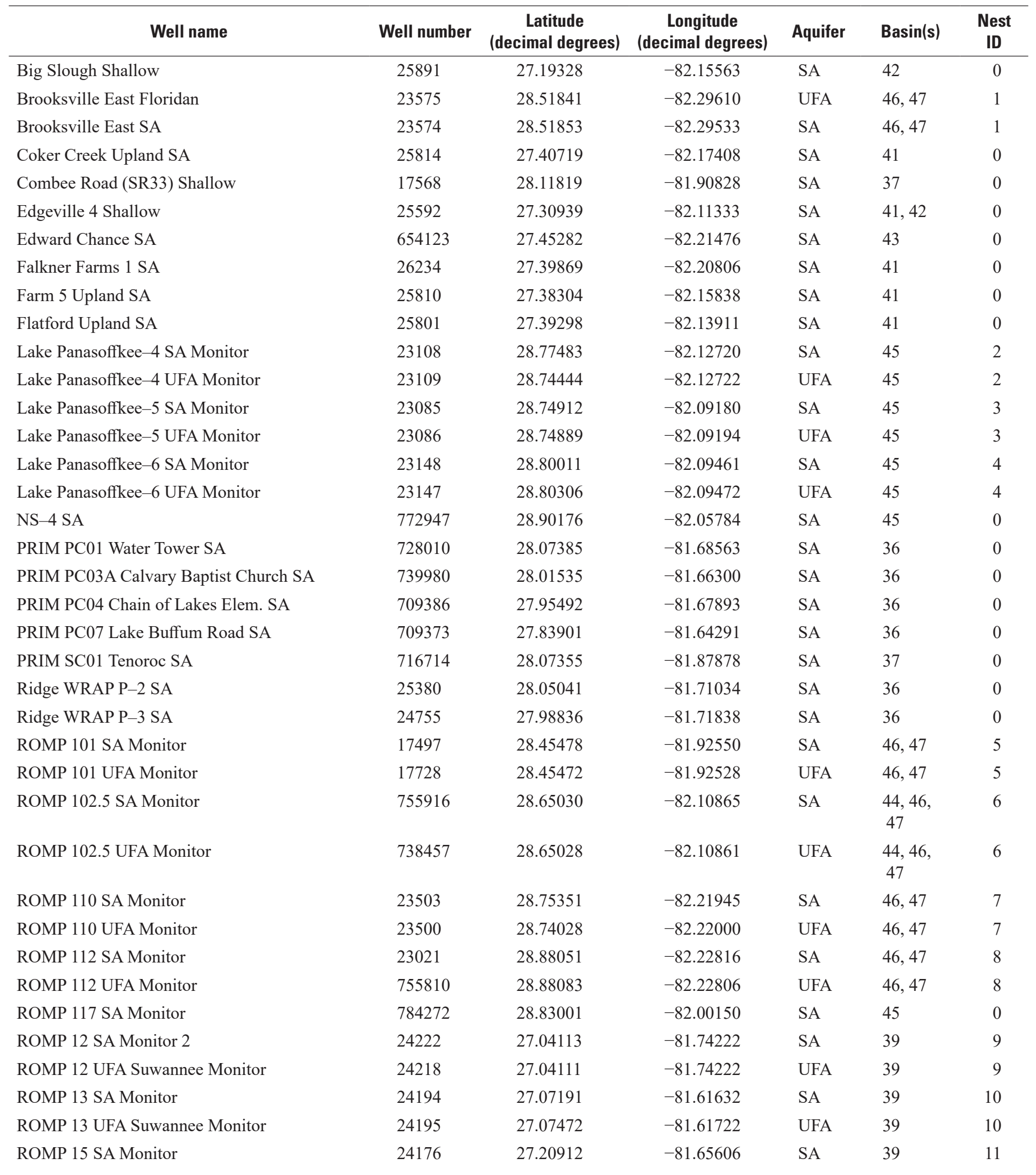


Table 8. Surficial and Upper Floridan aquifer wells used to determine changes in basin storage and leakage rates in Southwest Florida Water Management District (SWFWMD) basins._-Continued

[Well name and well number, name and number of well provided in SWFWMD Data Portal; Basin(s), location of well (see table 2 and figure 2 for basin information and location); Nest ID, same number indicates wells used to calculate water-level differences between aquifers; SA, surficial aquifer; UFA, Upper Floridan aquifer; SA wells were used to calculate basin storage, including those with NEST ID equal to 0; SR, State Road; ROMP, Regional Observation Monitoring Program]

\begin{tabular}{|c|c|c|c|c|c|c|}
\hline Well name & Well number & $\begin{array}{c}\text { Latitude (decimal } \\
\text { degrees) }\end{array}$ & $\begin{array}{l}\text { Longitude (deci- } \\
\text { mal degrees) }\end{array}$ & Aquifer & Basin(s) & $\begin{array}{c}\text { Nest } \\
\text { ID }\end{array}$ \\
\hline ROMP 15 UFA Monitor Mod & 24175 & 27.20889 & -81.65611 & UFA & 39 & 11 \\
\hline ROMP 16 UFA Monitor & 24104 & 27.18417 & -81.77417 & UFA & 38 & 12 \\
\hline ROMP 16.5 SA Monitor 1 & 24355 & 27.06121 & -81.88399 & SA & 38,40 & 13 \\
\hline ROMP 18 UFA Suwannee Monitor & 25878 & 27.19306 & -82.13000 & UFA & 42 & 14 \\
\hline ROMP 22 SA Monitor & 25711 & 27.31211 & -82.33658 & SA & 41,42 & 15 \\
\hline ROMP 22 UFA Suwannee Monitor & 25714 & 27.31194 & -82.33806 & UFA & 41,42 & 15 \\
\hline ROMP 23 SA Monitor & 26215 & 27.31484 & -82.17756 & SA & 41,42 & 16 \\
\hline ROMP 5 SA Monitor 2 & 25096 & 26.94581 & -81.80770 & SA & 40 & 18 \\
\hline ROMP 5 UFA Suwannee Monitor & 25090 & 26.94556 & -81.80806 & UFA & 40 & 18 \\
\hline ROMP 57 SA Monitor Replacement & 25344 & 27.90359 & -81.62251 & SA & 36 & 19 \\
\hline ROMP 57 UFA Monitor & 25343 & 27.90306 & -81.62222 & UFA & 36 & 19 \\
\hline ROMP 58 SA Monitor & 25240 & 27.91981 & -81.59394 & SA & 36 & 20 \\
\hline ROMP 58 UFA Monitor & 25241 & 27.91972 & -81.59389 & UFA & 36 & 20 \\
\hline ROMP 70 SA Monitor & 24917 & 28.07150 & -81.95544 & SA & 37 & 21 \\
\hline ROMP 70 UFA Monitor & 24916 & 28.07111 & -81.95556 & UFA & 37 & 21 \\
\hline ROMP 76 SA Monitor & 17698 & 28.18267 & -81.83056 & SA & 46,47 & 32 \\
\hline
\end{tabular}

where

$$
\begin{array}{cl}
A_{L_{i}} & \text { is the area of gaged lake } i, \\
A & \text { is the total basin area, } \\
\Delta h_{L_{i}} & \text { was approximated for each gaged lake in the } \\
& \text { basin from the difference between ending } \\
& \text { and starting stages of each year, and }
\end{array}
$$

$\Delta h \quad$ was approximated for each well in the basin from the difference between ending and starting water levels of each year.

Equation 12 was applied to basins with 10 percent or more of lake area and for which the lake stage data were available. 
Table 9. Surficial and Upper Floridan aquifer wells used to determine changes in basin storage and leakage rates in Tampa Bay Water (TBW) basins.

[Well name and number, name and number of well provided in TBW database; Basin(s), location of well (see table 2 and figure 2 for basin information and location); Nest ID, same number indicates wells used to calculate water-level differences between aquifers; SA, surficial aquifer well used to calculate basin storage, including those with Nest ID equal to 0; UFA, Upper Floridan aquifer; ROMP, Regional Observation Monitoring Program; SCH-SCHM, NWH-RMP, CNR, CNR-CM, CYB, CYC, STK, CB, parts of well names used by TBW]

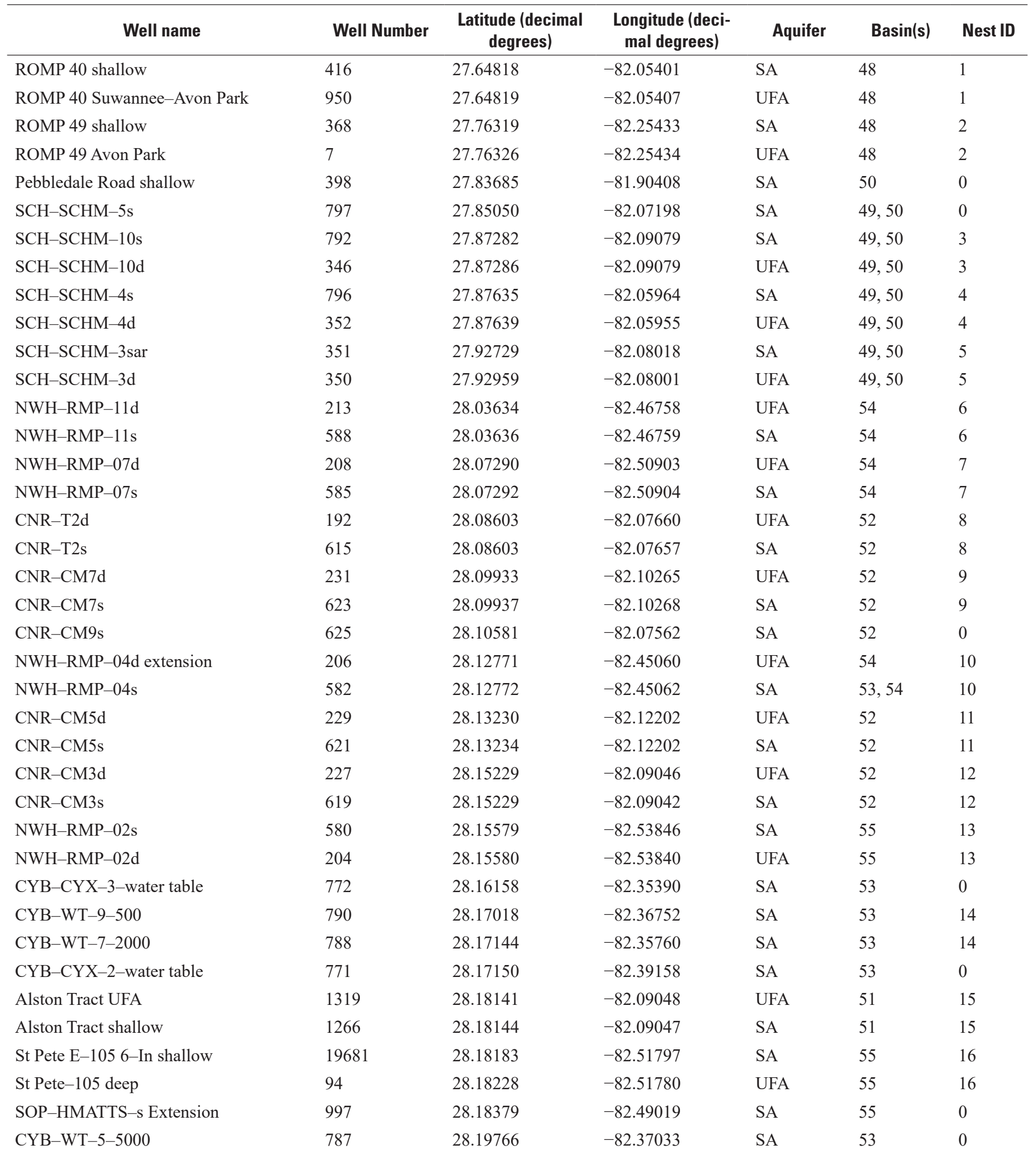


Table 9. Surficial and Upper Floridan aquifer wells used to determine changes in basin storage and leakage rates in Tampa Bay Water (TBW) basins.-Continued

[Well name and number, name and number of well provided in TBW database; Basin(s), location of well (see table 2 and figure 2 for basin information and location); Nest ID, same number indicates wells used to calculate water-level differences between aquifers; SA, surficial aquifer well used to calculate basin storage, including those with Nest ID equal to 0; UFA, Upper Floridan aquifer; ROMP, Regional Observation Monitoring Program; SCH-SCHM, NWH-RMP, CNR, CNR-CM, CYB, CYC, STK, CB, parts of well names used by TBW]

\begin{tabular}{|c|c|c|c|c|c|c|}
\hline Well name & Well Number & $\begin{array}{c}\text { Latitude (decimal } \\
\text { degrees) }\end{array}$ & $\begin{array}{l}\text { Longitude (deci- } \\
\text { mal degrees) }\end{array}$ & Aquifer & Basin(s) & Nest ID \\
\hline CYB-CYX-4-water table & 773 & 28.20995 & -82.35313 & SA & 53 & 0 \\
\hline Ledantec Property deep & 118 & 28.21563 & -82.51755 & UFA & 55 & 17 \\
\hline Ledantec Property shallow & 497 & 28.21563 & -82.51755 & SA & 55 & 17 \\
\hline Plaza Materials UFA & 1230 & 28.21686 & -82.13689 & UFA & 51 & 18 \\
\hline Plaza Materials shallow & 1228 & 28.21688 & -82.13686 & SA & 51 & 18 \\
\hline CYB-WT-2-1000 & 990 & 28.22401 & -82.36487 & SA & 53 & 0 \\
\hline STK-PZ-1d & 221 & 28.23863 & -82.57973 & UFA & 55 & 19 \\
\hline STK-EMW-08s & 602 & 28.23866 & -82.57973 & SA & 55 & 19 \\
\hline CYB-CYX-1-water table & 770 & 28.23886 & -82.40152 & SA & 53 & 0 \\
\hline CYB-CYX-5-water table & 774 & 28.24024 & -82.32371 & SA & 53 & 0 \\
\hline Howard Street UFA & 1197 & 28.24539 & -82.09856 & UFA & 51 & 20 \\
\hline Howard Street shallow & 1196 & 28.24569 & -82.09836 & SA & 51 & 20 \\
\hline STK-SM-2s & 631 & 28.24645 & -82.59526 & SA & 55 & 0 \\
\hline STK-WT-15s & 635 & 28.24661 & -82.56316 & SA & 55 & 0 \\
\hline STK-BEXLEY-1s & 984 & 28.25373 & -82.54376 & SA & 55 & 0 \\
\hline Wesley Chapel WWTP surficial & 1276 & 28.26664 & -82.32914 & SA & 53 & 21 \\
\hline Wesley Chapel WWTP UFA & 1275 & 28.26672 & -82.32914 & UFA & 53 & 21 \\
\hline CYC-TMR-4s Extension & 634 & 28.28086 & -82.41235 & SA & 53 & 0 \\
\hline CYC-TMR-2s-R & 633 & 28.31260 & -82.37802 & SA & 53 & 0 \\
\hline ROMP 93 shallow & 382 & 28.32355 & -82.42253 & SA & 53 & 22 \\
\hline ROMP 93 Suwannee-Avon Park & 18 & 28.32355 & -82.42252 & UFA & 53 & 22 \\
\hline ROMP BR-3 UFA & 1273 & 28.32714 & -82.23703 & UFA & 51 & 23 \\
\hline ROMP BR-3 shallow & 1274 & 28.32722 & -82.23706 & SA & 51 & 23 \\
\hline San Antonio Park UFA & 1282 & 28.34464 & -82.27789 & UFA & 53 & 24 \\
\hline San Antonio Park surficial & 1281 & 28.34469 & -82.27786 & SA & 53 & 24 \\
\hline CB 3E B shallow & 557 & 28.37303 & -82.40551 & SA & 53 & 25 \\
\hline CB 3E B deep & 172 & 28.37304 & -82.40552 & UFA & 53 & 25 \\
\hline
\end{tabular}

\section{Evaluation of SSEBop Rates}

The efficacy of the bias corrections applied to each landuse type was evaluated by analysis of regression equations and of root-mean-square error (RMSE) between SSEBop rates and the point (mETa), basin (wbETa), and statewide (luETa) estimates of ETa. Note that bias corrections result in a mean bias of zero and RMSE quantifies scattered about the mean of zero. Methods to calculate the RMSE are described by Helsel and Hirsch (2002) and can be interpreted as the standard deviation of bias (model minus observed). RMSE values were calculated with and without bias correction of SSEBop rates to assess the reduction in bias from stratification by land-use type. The datasets of uncorrected and bias-corrected SSEBop rates, $\mathrm{mETa}$ rates, uncorrected and bias-corrected wbETa rates, and luETa rates are available in the associated data release (Sepúlveda, 2021).

\section{Evaluation of SSEBop Rates at the Point Scale}

SSEBop rates were evaluated at the point scale by comparison with mETa rates at locations of MEF stations. Regression between SSEBop ${ }_{u}$ and mETa rates based on all MEF stations had a coefficient of determination $\left(\mathrm{R}^{2}\right)$ of 0.37 (fig. 11A) which indicates a weak positive relationship; only 
Table 10. Surficial aquifer wells used to determine changes in basin storage in St. Johns River Water Management District (SJRWMD) basins.

[Well name and number, name and number of surficial aquifer well provided in SJRWMD Data Portal; Basin(s), location of well (see table 2 and figure 2 for basin information and location]

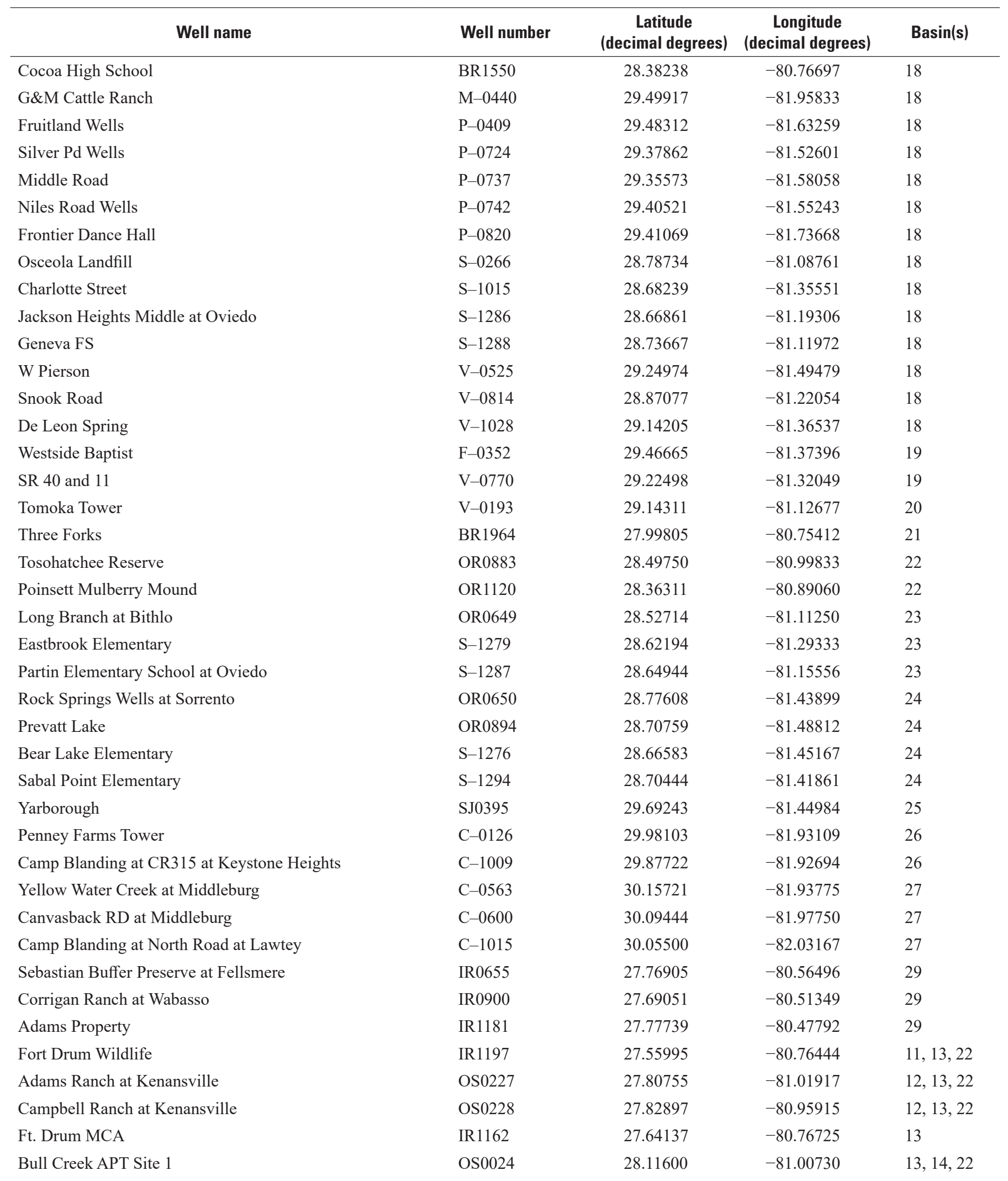


Table 10. Surficial aquifer wells used to determine changes in basin storage in St. Johns River Water Management District (SJRWMD) basins.-Continued

[Well name and number, name and number of surficial aquifer well provided in SJRWMD Data Portal; Basin(s), location of well (see table 2 and figure 2 for basin information and location]

\begin{tabular}{llccc}
\hline \multicolumn{1}{c}{ Well name } & Well number & $\begin{array}{c}\text { Latitude (decimal } \\
\text { degrees) }\end{array}$ & $\begin{array}{c}\text { Longitude (deci- } \\
\text { mal degrees) }\end{array}$ & Basin(s) \\
\hline SJWCD Wells & IR0947 & 27.57091 & -80.57855 & 13,18 \\
SJWCD HQ at South Vero Beach & IR0902 & 27.58762 & -80.57853 & $13,18,22$ \\
Blue Cypress Lake Ranch at Fellsmere City & IR0944 & 27.70839 & -80.77815 & 13,22 \\
Delta Farms at Fellsmere & IR0956 & 27.66156 & -80.63263 & 13,22 \\
Crooked R Preserve & L-1018 & 28.50836 & -81.75032 & 15 \\
Duda-Whittle Wells & L-1021 & 28.68876 & -81.70529 & 15 \\
Plymouth Tower & OR0107 & 28.70836 & -81.58089 & 15 \\
Lake Hiawasee & OR1100 & 28.52416 & -81.48281 & 15 \\
Johns LK E Wells & OR1121 & 28.52915 & -81.61037 & 15 \\
Crate Mill & OR0661 & 28.66686 & -81.50849 & 15,16 \\
Horsehead Pond & L-0050 & 28.37713 & -81.73560 & 16 \\
Carrot Barn & L-0703 & 28.89968 & -81.79069 & 16 \\
Leesburg wastewater treatment & L-0874 & 28.75028 & -81.92861 & 16 \\
Palatlakaha Dam M1 & L-0883 & 28.74389 & -81.87306 & 16 \\
Hilochee & L-0907 & 28.35779 & -81.73103 & 16 \\
Lake Griffin SP & L-0926 & 28.85611 & -81.89917 & 16 \\
Leesburg Tower & L-0289 & 28.86255 & -81.79685 & 16,18 \\
Smokehouse Lake Wells & L-0710 & 28.42452 & -81.71320 & 16,18 \\
Camp Kateri & P-0168 & 29.51750 & -81.96528 & 17 \\
Alachua Fair Grounds & A-0702 & 29.68465 & -82.28693 & 17,18 \\
Alafaya Trail WTP at Union Park & OR0665 & 28.50213 & -81.19597 & 18,23 \\
Tiger Bay Mile West & V-1089 & 29.16839 & -81.18658 & 19,20 \\
Erna Nixon Park & BR1981 & 28.08761 & -80.65533 & 21,28 \\
\hline
\end{tabular}

37 percent of the variance in the data is common to both SSEBop $_{u}$ and mETa rates, and 63 percent is unexplained (see Griffiths [1967] p. 460 for a generalized discussion of the use of the coefficient of determination). Bias correction alone will not change $\mathrm{R}^{2}$ values, but stratification by land-use type might improve $\mathrm{R}^{2}$ values. When stratified by land-use type, contrasts between ETa data are apparent. There is a great deal of scatter in ETa rates for open-water surfaces around the 1:1 slope line (fig. 11A). In addition, pasture, and forested wetland data plot below the 1:1 slope line, indicating that the SSEBop overestimates ETa for these land-use types. The $\mathrm{R}^{2}$ values for regressions applied to each land-use type ranged from 0.59 for the forest station to 0.82 for the shallow-water-table pasture stations (table 12). Bias corrections were applied to all stations by using either equation 2 or 6 and were stratified and bias corrected by land-use type. The result was an improvement in regression fit, with $\mathrm{R}^{2}$ values increasing from 0.37 (fig. 11A) to 0.79 (fig. 11B).
Further improvement in the regression fit for bias corrections of SSEBop rates was considered by stratifying data by seasons. Stratification by season was not feasible for this study but is discussed later in this section. For this report, months are assigned to seasons as follows: December, January, and February for winter; March, April, and May for spring; June, July, and August for summer; and September, October, and November for fall.

The RMSE values of bias in uncorrected monthly SSEBop rates (mETa minus SSEBop ${ }_{u}$ ) stratified by land-use type ranged from $0.60 \mathrm{in} / \mathrm{mo}$ for urban land-use type to $1.66 \mathrm{in} / \mathrm{mo}$ for open-water surface (table 12). RMSE values of bias after bias correction of monthly SSEBop rates (mETa minus SSEBop) stratified by land-use type varied from $0.50 \mathrm{in} / \mathrm{mo}$ for urban land-use type to $0.91 \mathrm{in} / \mathrm{mo}$ for open-water surface. The overall RMSE of bias was reduced from $1.27 \mathrm{in} / \mathrm{mo}$ before bias corrections to $0.73 \mathrm{in} / \mathrm{mo}$ after bias corrections. This compares to average mETa rates for all stations of $3.78 \mathrm{in} / \mathrm{mo}$ and $45.35 \mathrm{in} / \mathrm{yr}$. RMSE values of bias in annual 
Table 11. Upper Floridan aquifer wells used to determine changes in basin storage in Suwannee River Water Management District (SRWMD) basins.

[Well name and number, name and number of Upper Floridan aquifer well provided in SRWMD Data Portal or in U.S. Geological Survey (USGS) National Water Information System for wells in Georgia (USGS, 2018b); Basin(s), location of well (see table 2 and figure 2 for basin information and location)]

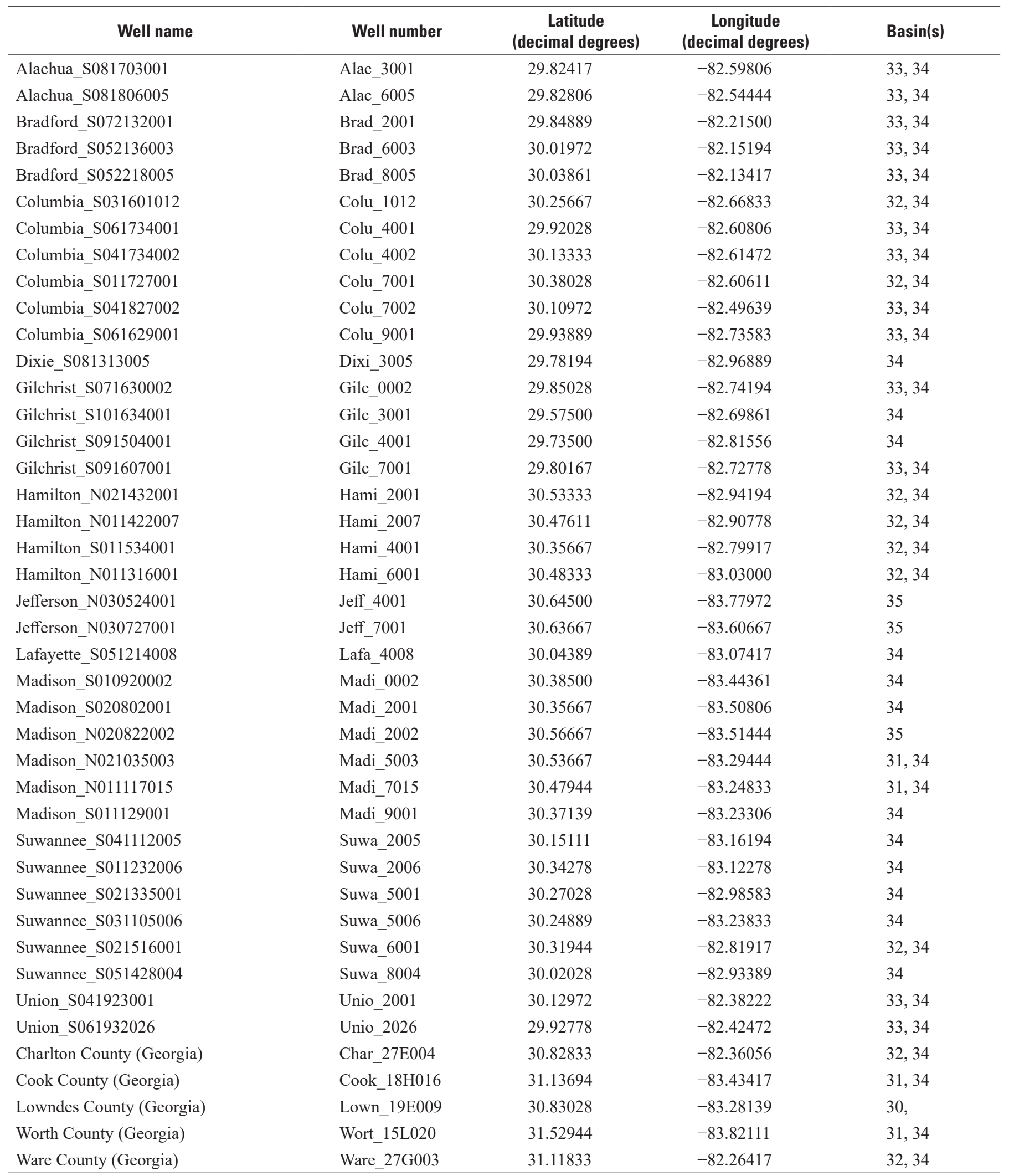


totals of bias-corrected SSEBop rates, based on differences from annual mETa rates for stations with complete years of records, ranged from $2.01 \mathrm{in} / \mathrm{yr}$ for agriculture to $5.73 \mathrm{in} / \mathrm{yr}$ for the deep-water-table pasture, or 4.96 percent of annual $\mathrm{mETa}$ rate $40.51 \mathrm{in} / \mathrm{yr}$ and 21.21 percent of annual mETa rate $27.03 \mathrm{in} / \mathrm{yr}$, respectively. The 21.21 percent error in the landuse type of deep-water-table pasture may be caused by the relatively low annual mETa rates at station 22 (fig. 1) of 30.98 , 26.94, 27.61, 22.40, and $27.23 \mathrm{in} / \mathrm{yr}$ during 2001, 2003, 2004, 2005, and 2006, respectively (Sepúlveda, 2021). The generally dry conditions during these years, which averaged $27.03 \mathrm{in} / \mathrm{yr}$ for $\mathrm{mETa}$, had an annual average bias-corrected SSEBop rate of $31.27 \mathrm{in} / \mathrm{yr}$ during the same years (table 12).

\section{Subset Land-Use Types}

ETa rates computed from MEF station data were stratified by generalized land-use types, and some of these types were further stratified. Three MEF stations were in the generalized land-use type of forested wetland: Cypress Swamp, Dwarf Cypress, and Dead River Forest (MEF stations 7, 8, and 16, fig. 1, table 1). SSEBop rates at the Dead River Forest site, characterized by a high canopy density (Swancar, 2016), were generally larger than those at the Cypress Swamp and Dwarf Cypress sites, characterized by a low to medium canopy density (Shoemaker and others, 2011). The land-use type of forested wetland was further stratified into two types: low to medium canopy density forested wetland and high canopy density forested wetland. Scatterplots of these two types show most of the data from Cypress Swamp and Dwarf Cypress below the 1:1 slope line (fig. 12), while Dead River Forest data plot both above and below the 1:1 slope line. This suggests that the larger the density of vegetation canopy in a forested wetland, such as at the Dead River Forest site, the larger the ETa losses because more transpiration takes place in a larger surface area as the density of vegetation canopy increases.

Four mETa stations in the generalized land-use type of pasture were further stratified: Disney Preserve, Starkey Pasture (Swancar, 2017a), Duda Farms, and Ferris Farms (U.S. Geological Survey, 2018b; MEF stations 15, 18, 19, and 22, fig. 1, table 1). The first three of these stations are under shallow water-table conditions, and Ferris Farms is, most of the time, under deep water-table conditions This stratification is based on scatterplots that show most of the SSEBop rates from the Ferris Farms station below the 1:1 slope line (fig. 13). This reflects that mETa rates decrease as the depth to water from land surface increases, indicative of deep water-table conditions at Ferris Farms. Shallow water-table conditions could reflect a slightly lower LST that may not be reflected by the ETf value (fig. 3). The classification of pasture into two land-use types, shallow and deep water-table conditions, was determined by the mETa rates at the stations.

\section{Stratification of Bias by Season}

Bias correction stratified by season was also considered in this study; however, associated regression equations did not have consistent slopes for given land-use types and had small values. The calibration of equation 1 or 2 to seasonal $\left(\mathrm{mETa}, \mathrm{SSEBop}_{\mathrm{u}}\right.$ ) estimates from the MEF stations in agricultural land-use types resulted in nearly constant bias-corrected SSEBop rates for winter and summer seasons. Dimensionless slopes of equation 2 were -0.04 and -0.07 , and $\mathrm{R}^{2}$ values were 0.001 and 0.09 for the summer and winter seasons, respectively (fig. 14). $\mathrm{R}^{2}$ values for the spring and fall seasons were higher than those for the winter and summer seasons; however, the regression explained only 45 and 64 percent of the variability in the scatterplots for spring and fall, respectively. Similar results to those observed at MEF stations in agricultural land-use types occurred with seasonal (mETa, SSEBop $\left.{ }_{u}\right)$ estimates for the open-water surface stations (fig. 15). The low power regressed for equation 6 for open-water surface stations caused nearly constant bias-corrected SSEBop rates during the summer and winter months. Low $\mathrm{R}^{2}$ values for the winter (0.002), spring (0.349), and summer (0.015) seasons made the regressions less accurate for the calculation of bias-corrected SSEBop ETa rates (fig. 15). Given inconsistencies and uncertainties in regression models when stratified by season, regression relationships used to calculate and correct for bias were based on monthly data for the entire year, rather than stratified by season.

\section{Least-Squares Regression Equations Stratified by Land-Use Type}

Least-squares regression was used to quantify and

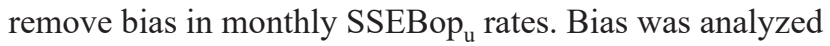
by using two scatterplots: (1) bias and SSEBop $\mathrm{p}_{\mathrm{u}}$ rates and (2) residuals and SSEBop rates. Linear or power-function regression lines were fit to scatterplots which were generated for each land-use type (figs. 16-24).

The linear regression fit to monthly bias (mETa minus SSEBop $_{u}$ ) and SSEBop rates (graphs labeled $A$ in figs. 16-24) exhibited an inverse relationship, as indicated by a negative slope for linear regressions ("m-1" column in table 12), for

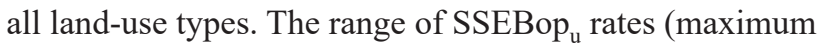
minus minimum) was greater than that for bias-corrected SSEBop rates for all land-use types (table 13). The range of bias for $\mathrm{SSEBop}_{\mathrm{u}}$ was greater than the range of residuals for bias-corrected SSEBop in all land-use types (table 13), showing the bias reduction in all land-use types (figs. 16-24). The parameters for the regression line for open-water surface (fig. 24A) is nonlinear; a power-function regression was used for this land-use type (eq. 7). A scatterplot with regression of residuals and SSEBop for open-water surface (fig. 24B) illustrates the reduction in bias between mETa and SSEBop. Scatter plots (figs. $24 A, B$ ) illustrate that there are two clusters of residuals with one cluster of SSEBop (or SSEBop ${ }_{u}$ ) less 
Table 12. Regression and error statistics between actual evapotranspiration computed by using micrometeorological station data (mETa) and Operational Simplified Surface Energy Balance (SSEBop) rates before and after bias corrections for each generalized land-use type.

$\left[N P\right.$, number of monthly measurements in land-use type; $m, b$, regressors used in SSEBop $=m$ SSEBop $_{u}+b$ for all but open-water surfaces, and used in SSEBop $=b$ SSEBop ${ }_{u}{ }^{m}$ for open-water surfaces; $\mathrm{R}^{2}$, coefficient of determination from regression between mETa and bias-corrected SSEBop, dimensionless; RMSE SSEBop , RMSE SSEBop, root-mean-square error between monthly uncorrected and biascorrected SSEBop and mETa rates, respectively; in/mo, inches per month; ARM, RMSE between annual bias-corrected SSEBop and annual mETa rate at station; in/yr, inches per year; Annual mETa, average $\mathrm{mETa}$ from years of complete monthly data at station; Annual SSEBop ETa (actual evapotranspiration), average ETa from SSEBop from same years for which annual mETa was computed; Percentage annual error, average percentage error between annual SSEBop ETa rates and annual mETa at station(s); Percentage ARM error, average percentage error between ARM and annual mETa rates at station(s); LMCD, low to medium canopy density; HCD, high canopy density]

\begin{tabular}{|c|c|c|c|c|c|c|c|c|c|c|c|c|}
\hline Land-use type & NP & $\mathbf{m}$ & m-1 & b & $\mathbf{R}^{2}$ & $\begin{array}{c}\text { RMSE } \\
\text { SSEBop }_{\mathrm{u}} \\
\text { (in/mo) }\end{array}$ & $\begin{array}{l}\text { RMSE } \\
\text { SSEBop } \\
\text { (in/mo) }\end{array}$ & $\begin{array}{c}\text { ARM } \\
\text { (in/yr) }\end{array}$ & $\begin{array}{c}\text { Annual } \\
\text { mETa } \\
\text { (in/yr) }\end{array}$ & $\begin{array}{c}\text { Annual } \\
\text { SSEBop Eta } \\
\text { (in/yr) }\end{array}$ & $\begin{array}{l}\text { Percentage } \\
\text { annual error }\end{array}$ & $\begin{array}{c}\text { Percentage } \\
\text { ARM error }\end{array}$ \\
\hline Agriculture & 77 & 0.64 & -0.36 & 1.35 & 0.75 & 0.80 & 0.56 & 2.01 & 40.51 & 39.14 & -3.38 & 4.96 \\
\hline Forest & 115 & 0.54 & -0.46 & 1.11 & 0.59 & 1.20 & 0.76 & 4.56 & 36.41 & 36.58 & 0.46 & 12.54 \\
\hline Forested wetland LMCD & 70 & 0.66 & -0.34 & 0.29 & 0.72 & 1.50 & 0.61 & 2.47 & 41.89 & 40.34 & -3.70 & 5.89 \\
\hline Forested wetland HCD & 75 & 0.64 & -0.36 & 0.85 & 0.66 & 1.26 & 0.77 & 5.49 & 44.98 & 44.97 & -0.03 & 12.21 \\
\hline Marsh & 376 & 0.66 & -0.34 & 0.98 & 0.66 & 1.03 & 0.74 & 5.50 & 45.99 & 46.17 & 0.40 & 11.95 \\
\hline Pasture, deep water table & 75 & 0.59 & -0.41 & 0.53 & 0.77 & 1.41 & 0.52 & 5.73 & 27.03 & 31.27 & 15.68 & 21.21 \\
\hline Pasture, shallow water table & 225 & 0.67 & -0.33 & 0.51 & 0.82 & 1.08 & 0.53 & 2.64 & 33.49 & 34.92 & 4.26 & 7.89 \\
\hline Urban & 44 & 0.68 & -0.32 & 0.98 & 0.64 & 0.60 & 0.50 & 4.60 & 34.90 & 34.42 & -1.36 & 13.19 \\
\hline Open-water surface & 361 & 0.41 & -0.59 & 3.15 & 0.67 & 1.66 & 0.91 & 5.14 & 60.93 & 58.35 & -4.23 & 8.43 \\
\hline $\begin{array}{l}\text { Bias-corrected based on land use, all } \\
\text { stations combined }\end{array}$ & 1,418 & 1.04 & 0.04 & -0.14 & 0.79 & 1.27 & 0.73 & 4.68 & 45.35 & 44.31 & -2.29 & 10.33 \\
\hline
\end{tabular}



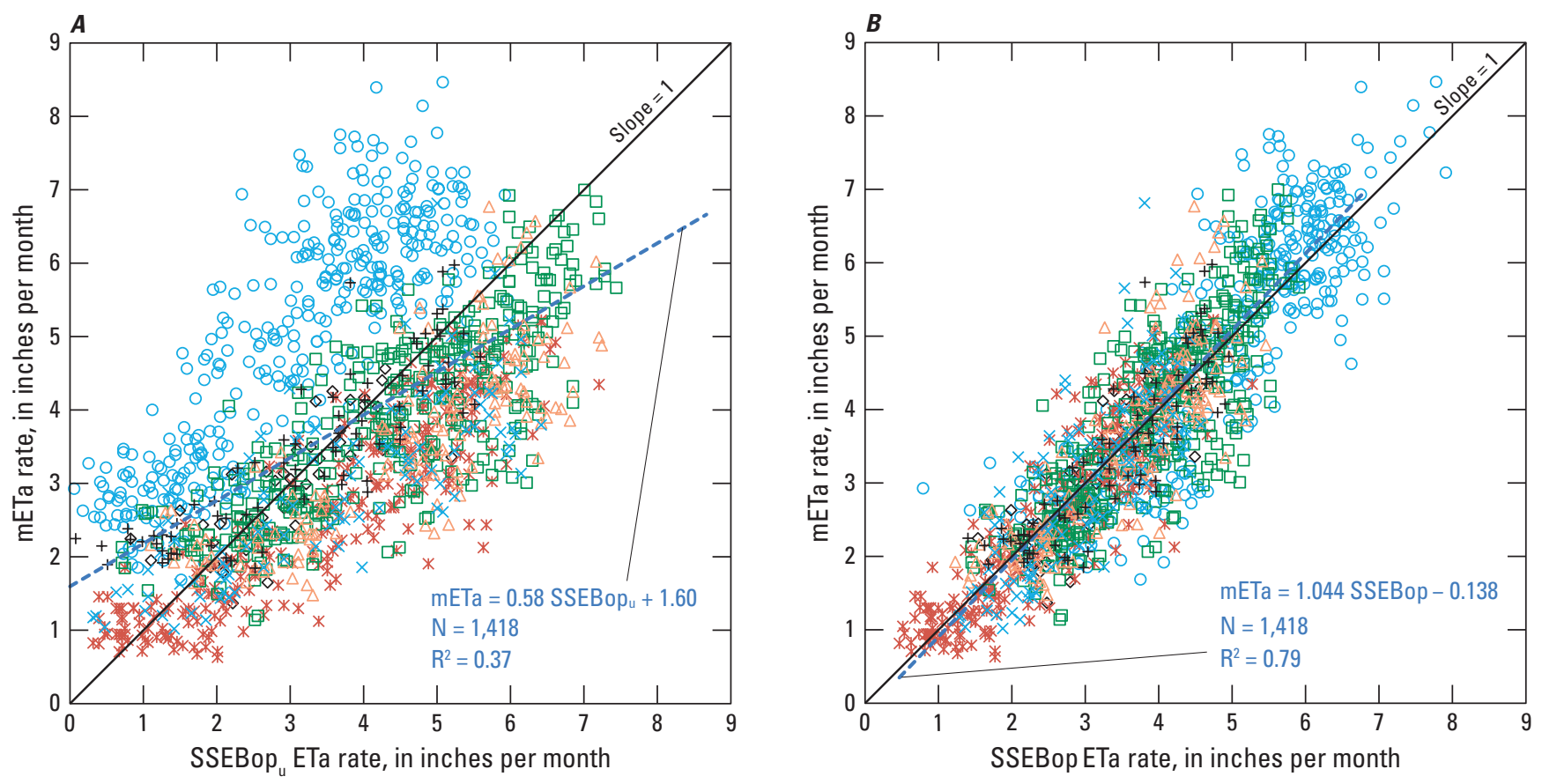

EXPLANATION

Generalized land-use types

+ Agriculture
$\times \quad$ Forest
$\triangle \quad$ Forested wetland (all canopy densities)
$\square \quad$ Marsh

$*$ Pasture (deep and shallow water table)
$\diamond$ Urban
$\circ \quad$ Open-water surfaces

Figure 11. A, Monthly uncorrected Operational Simplified Surface Energy Balance (SSEBop $)$ actual evapotranspiration (ETa) rates versus evapotranspiration rates calculated from micrometeorological station (mETa) data for all station locations and all land uses, and $B$, bias-corrected monthly Operational Simplified Surface Energy Balance (SSEBop) ETa rates versus actual evapotranspiration rates measured at all evapotranspiration (ET) stations. [N, number of measurements; $\mathrm{R}^{2}$, coefficient of determination]

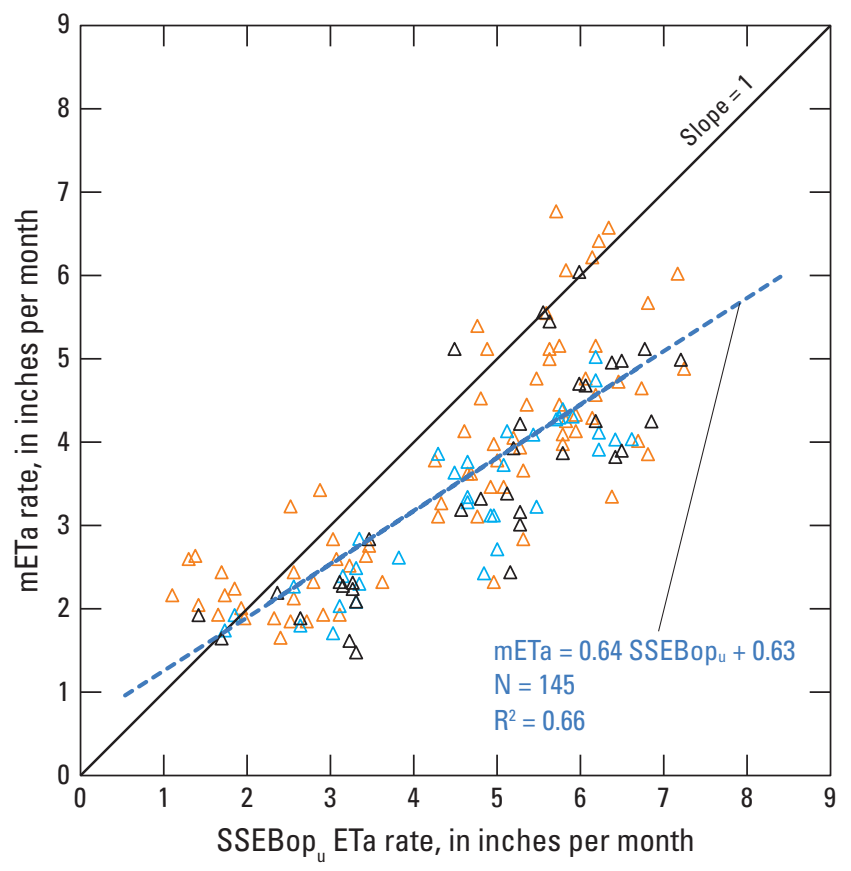

\section{EXPLANATION}

MEF stations in generalized land-use type of forested wetland

$\Delta \quad$ Cypress Swamp

$\Delta \quad$ Dwarf Cypress

$\triangle \quad$ Dead River Forest

Figure 12. Monthly uncorrected Operational Simplified Surface Energy Balance (SSEBop $)$ actual evapotranspiration (ETa) rates versus actual evapotranspiration rates computed by using observations at micrometeorological stations ( $\mathrm{mETa}$ ) located in the generalized land-use type of forested wetland. $\left[\mathrm{N}\right.$, number of measurements; $\mathrm{R}^{2}$, coefficient of determination] 


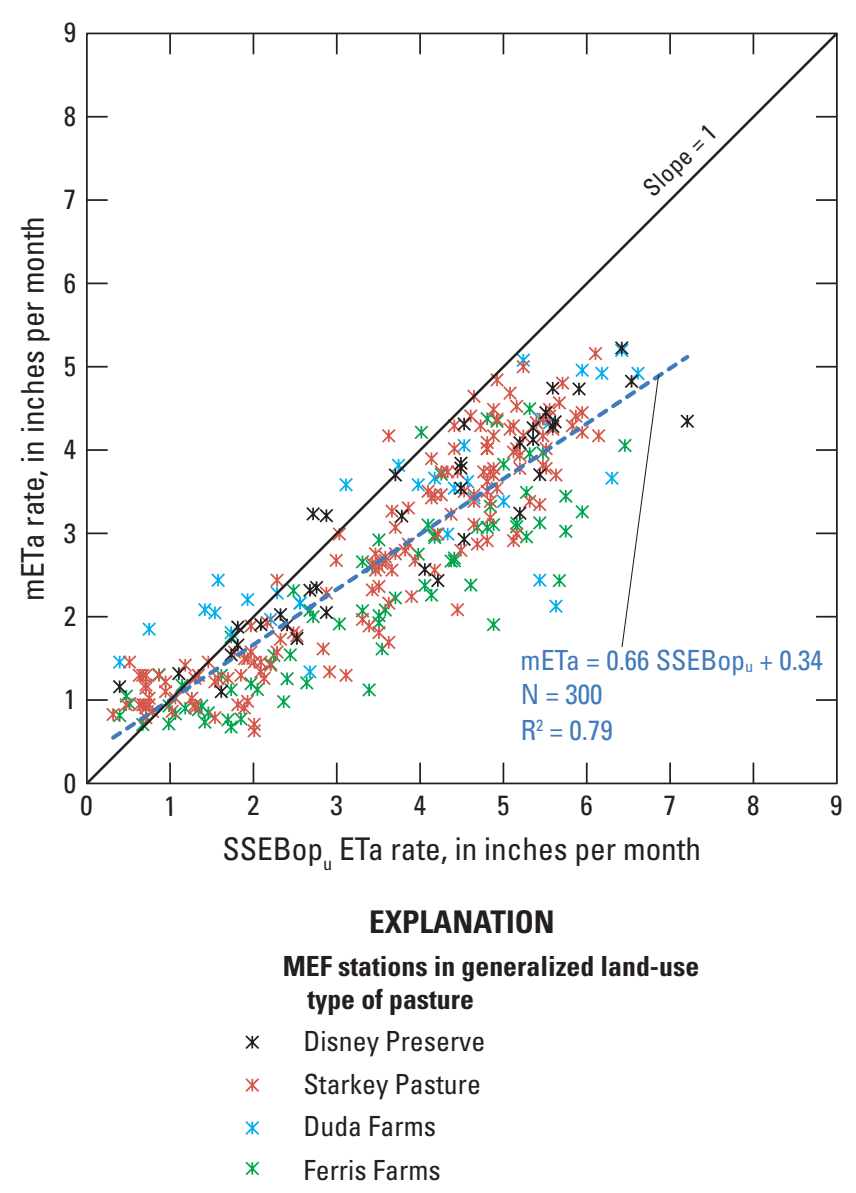

Figure 13. Monthly uncorrected Operational Simplified Surface Energy Balance (SSEBop ${ }_{u}$ ) actual evapotranspiration (ETa) rates versus actual evapotranspiration rates computed by using data at micrometeorological stations ( $\mathrm{mETa}$ ) located in the generalized land-use type of pasture. [N, number of measurements; $\mathrm{R}^{2}$, coefficient of determination]

than $2.5 \mathrm{in} / \mathrm{mo}$ and representing about November through March (cold season) evapotranspiration and the second cluster representing other months; however, as previously discussed in the "Stratification of Bias by Season" section, seasonal bias corrections resulted in low $\mathrm{R}^{2}$ values (fig. 15).

Another visual way to characterize the bias-corrected SSEBop rates by land-use type is to graph the ratio of annual SSEBop rate to annual rainfall versus concurrent annual rainfall. This rainfall normalization graph, one of many introduced by Mikhail Budyko to the field of hydrology (Gnann and others, 2019), provides regression parameters that characterize the ETa response of a land-use type. Budyko graphs for land-use types show best-fit regressions with dimensionless intercepts between 1.17 and 2.34 and negative slopes between -0.011 and $-0.022 \mathrm{yr} / \mathrm{in}$ from all land-use types (graphs labeled $C$ in figs. 16-24). The slope regressor for open-water surfaces was the largest in absolute value. Budyko graphs with different slope and intercept regressors for pasture cells support the reclassification of this land-use type into two generalized land-use types for pasture: pasture under deep water-table conditions and pasture under shallow water-table conditions (figs. $21 C$ and $22 C$, respectively).

\section{Evaluation of SSEBop at the Basin Scale}

Residuals at the basin scale were computed as the difference between average annual wbETa rates from the water-balance method for a basin and the average annual bias-corrected SSEBop rates (wbETa minus SSEBop) calculated over all grid cells within each basin. Residuals ranged from $-3.67 \mathrm{in} / \mathrm{yr}$ for the Suwannee River Basin (number 34 in table 14), which includes basins 30-34 (figs. 2 and 25), to 5.29 in/yr for the Eau Gallie River Basin (number 28 in table 14, figs. 2 and 25). These residuals range from an underestimation of 9.24 percent to an overestimation of 17.36 percent relative to the average annual wbETa rate. The overall RMSE values between the wbETa rates and the bias-corrected SSE-

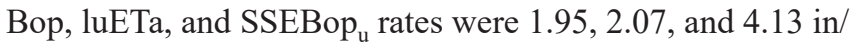
$\mathrm{yr}$, respectively (table 14), which correspond to normalized percentages of 5.2, 5.5, and 10.9 relative to an annual average wbETa rate of 37.79 inches for all basins. The annual average bias-corrected SSEBop ETa rate was 3.41 percent lower than the annual average wbETa rate of 37.79 inches for all basins (table 14). Results are presented in the following sections of this report in further detail by basin for Florida's five water management districts and Tampa Bay Water. Components of the water budget are discussed in units of height of water, converted by dividing volumetric fluxes by basin area.

\section{NWFWMD Basins}

Average annual wbETa, SSEBop, luETa, and SSEBop rates were calculated for basins $1-5$ located in the NWFWMD (table 14, fig. 26). Of the five NWFWMD basins, basins 1, 2,3 , and 5 had streamflow data for the entire 2000-17 period to apply to the water-balance method. The wbETa rates for these basins were calculated by using limited water-level data from wells to estimate changes in basin storage. The lack of springflow data for basin 3 was the main reason to include the Upper Floridan aquifer in the control volume for this basin; however, additional error may have been introduced if the surface-water basin is different from the groundwater basin. The control volume for basins 1, 2, 4, and 5 extends from the vegetation canopy to the bottom of the surficial aquifer. Leakage rates for these four basins were estimated from fluxes calculated from water-level differences in wells that tap the surficial or the Upper Floridan aquifer and are close to each other. Residuals for basins in the NWFWMD ranged from $-0.48 \mathrm{in} / \mathrm{yr}$ for the Yellow River Basin (basin 4) to $-2.0 \mathrm{in} / \mathrm{yr}$ for the Apalachicola-Chipola Basin (basin 2; fig. 26, table 14). Residuals for these basins were 1.36 and 5.21 percent underestimation of SSEBop compared to wbETa average annual rates, respectively. 

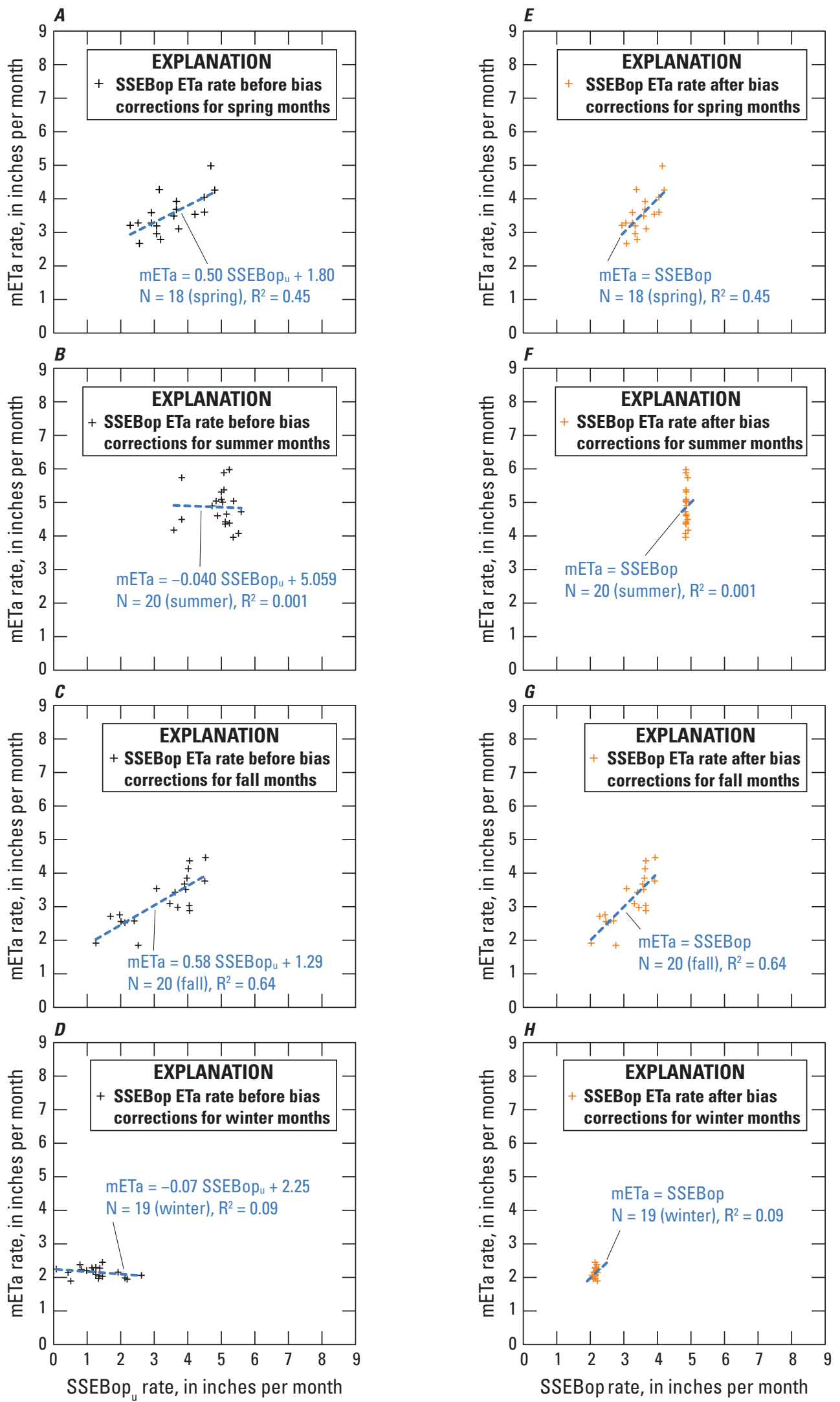

Figure 14. Actual evapotranspiration computed by using micrometeorological station data ( $\mathrm{mETa}$ ) and uncorrected Operational Simplified Surface Energy Balance (SSEBop $)$ ) rates at locations of micrometeorological stations in agricultural land-use types for, $A$, spring, $B$, summer, $C$, fall, and $D$, winter, and corresponding seasonal bias-corrected Operational Simplified Surface Energy Balance (SSEBop) rates for, $E$, spring, $F$, summer, $G$, fall, and $H$, winter. 

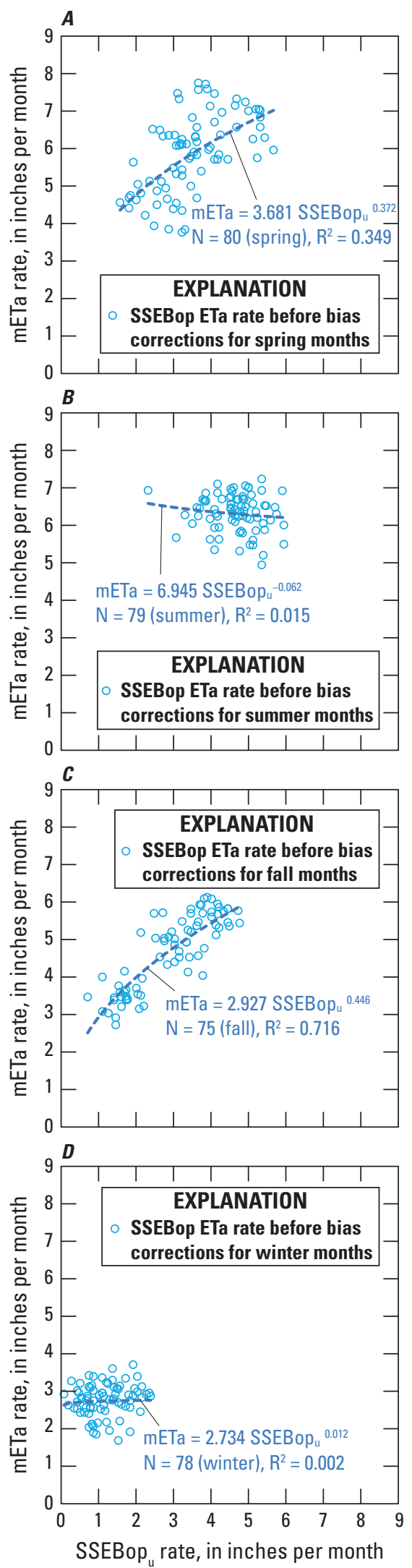
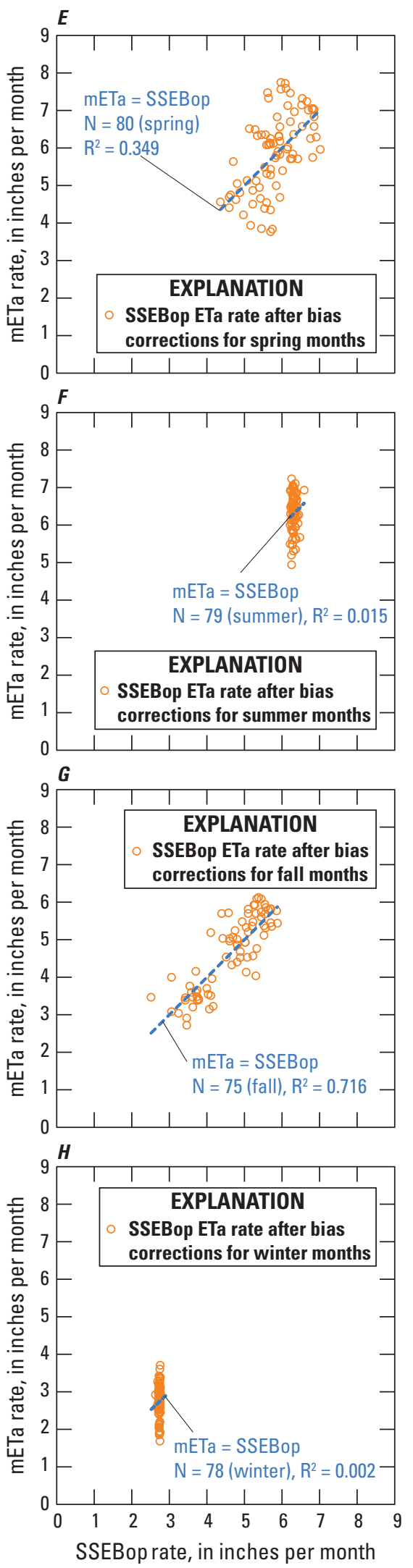

Figure 15. Actual evapotranspiration computed by using micrometeorological station data ( $\mathrm{mETa}$ ) and uncorrected Operational Simplified Surface Energy Balance (SSEBop $)$ ) rates at locations of micrometeorological stations in open-water surface surfaces for, $A$, spring, $B$, summer, $C$, fall, and $D$, winter, and corresponding seasonal bias-corrected Operational Simplified Surface Energy Balance (SSEBop) rates for, $E$, spring, $F$, summer, $G$, fall, and $H$, winter. 
Table 13. Ranges of uncorrected SSEBop (SSEBop ) actual evapotranspiration (ETa) rates, bias-corrected Operational Simplified Surface Energy Balance (SSEBop) ETa rates, actual evapotranspiration computed by using micrometeorological station data (mETa) minus SSEBop ${ }_{u}$, and mETa minus SSEBop for each generalized land-use type.

[SSEBop ${ }_{u}$, uncorrected SSEBop rates; SSEBop, bias-corrected SSEBop rates; mETa, evapotranspiration rate based on micrometeorological station data; USGS, U.S. Geological Survey; LMCD, low to medium canopy density; HCD, high canopy density; WT, water table]

\begin{tabular}{|c|c|c|c|c|c|c|}
\hline Land-use type & $\begin{array}{c}\text { Station } \\
\text { number } \\
\text { (table 1, fig. 1) }\end{array}$ & $\begin{array}{l}\text { Range in } \\
\text { SSEBop }_{u}\end{array}$ & $\begin{array}{l}\text { Range in } \\
\text { SSEBop }\end{array}$ & $\begin{array}{c}\text { Range in } \\
\text { bias for } \\
\text { mETa- } \\
\text { SEBop }_{u}\end{array}$ & $\begin{array}{l}\text { Range in } \\
\text { residuals for } \\
\text { mETa-SSEBop }\end{array}$ & Source of mETa data \\
\hline Forest & 24 & 6.10 & 3.29 & 4.82 & 4.41 & Bracho and others, 2012 \\
\hline Forested wetland LMCD & 7,8 & 5.79 & 3.83 & 3.35 & 3.12 & Shoemaker and others, 2011 \\
\hline Marsh & $1-6,9,13,23$ & 6.73 & 4.46 & 5.10 & 4.07 & $\begin{array}{l}\text { German, 2000; Sumner, 2017; } \\
\text { Shoemaker, } 2018\end{array}$ \\
\hline Pasture, deep WT & 22 & 6.06 & 3.59 & 3.81 & 2.82 & USGS, 2018b \\
\hline Pasture, shallow WT & $15,18,19$ & 6.89 & 4.65 & 4.61 & 3.40 & USGS, 2018b; Swancar, 2017a \\
\hline Urban & 21 & 4.49 & 3.03 & 3.26 & 2.02 & Sumner, 2017 \\
\hline
\end{tabular}

\section{SFWMD Basins}

Average annual wbETa, SSEBop, luETa, and SSEBop rates were calculated for basins 6-10 located in the SFWMD (table 14, fig. 27). None of the five basins in SFWMD had streamflow data for the entire 2000-17 period (table 14). The control volume for these basins extends from the vegetation canopy to the bottom of the surficial aquifer. Leakage rates for SFWMD basins are discussed in the "Basin Inflows and Outflows" section of this report. Residuals for basins in the SFWMD ranged from $-1.84 \mathrm{in} / \mathrm{yr}$ for the Boggy Creek Swamp (basin 6) to $1.79 \mathrm{in} / \mathrm{yr}$ for the Tidal South Basin (basin 10; fig. 27; table 14). Residuals for these two basins ranged from underestimating the annual average wbETa rate by 4.95 percent to overestimating the annual average wbETa rate by 5.35 percent, respectively.

\section{SJRWMD Basins}

Average annual wbETa, SSEBop, luETa, and SSEBop rates were calculated for basins 11-29 located in the SJRWMD (table 14, figs. 28 and 29). Of these 19 basins, only two (basins 17 and 18) had streamflow data for the entire 2000-17 period to apply the water-balance method (table 14). The control volume for these basins extends from the vegetation canopy to the bottom of the surficial aquifer. Leakage rates for these basins were calculated from maps of recharge to the Upper Floridan aquifer for the SJRWMD area for 1995, 2005, and 2015 (SJRWMD, 2016) and applied to year intervals 2000-04, 2005-14, and 2015-17, respectively. Basins 13, $14-19,22$, and 24 have a high-density distribution of surficial aquifer wells from which annual changes in basin storage were calculated (figs. 28 and 29). Upper Floridan aquifer springflow data for springs in basins 15, 16, 18, and 24 (figs. 28 and 29) were used to estimate springflow (eq. 10, fig. 10; Sepúlveda, 2021). Springflow was considered an inflow to the basin because the control volume used for these basins excludes the Upper Floridan aquifer; the Upper Floridan aquifer was assumed to be the source of all springflows.

Residuals for basins in the SJRWMD ranged from $-2.82 \mathrm{in} / \mathrm{yr}$ for the Haw Creek above Russell Landing Basin (basin 19; fig. 28, table 14) to 5.29 in/yr for the Eau Gallie River Basin (basin 28; fig. 29, table 14). These residuals ranged from an SSEBop underestimating wbETa rates by 7.10 percent to an overestimation by 17.36 percent, respectively. The overestimation by the SSEBop rate of 17.36 percent occurred in the smallest (4.684 $\mathrm{mi}^{2}$; table 2$)$ of all 55 basins included in the study. The relatively small size of this basin and its approximated basin delineation causes potential errors associated with each term in the water-balance method, which could increase the difference between wbETa and bias-corrected SSEBop rates.

\section{SRWMD Basins}

Average annual wbETa, SSEBop, luETa, and SSEBop $_{\mathrm{u}}$ rates were calculated for basins 30-35 located in the SRWMD (table 14, fig. 30). All these basins had complete flow data for the 2000-17 period to apply the water-balance method (table 14); however, the basins in the SRWMD were delineated considering the surface-water contributing areas, which may be different from the groundwater contributing 

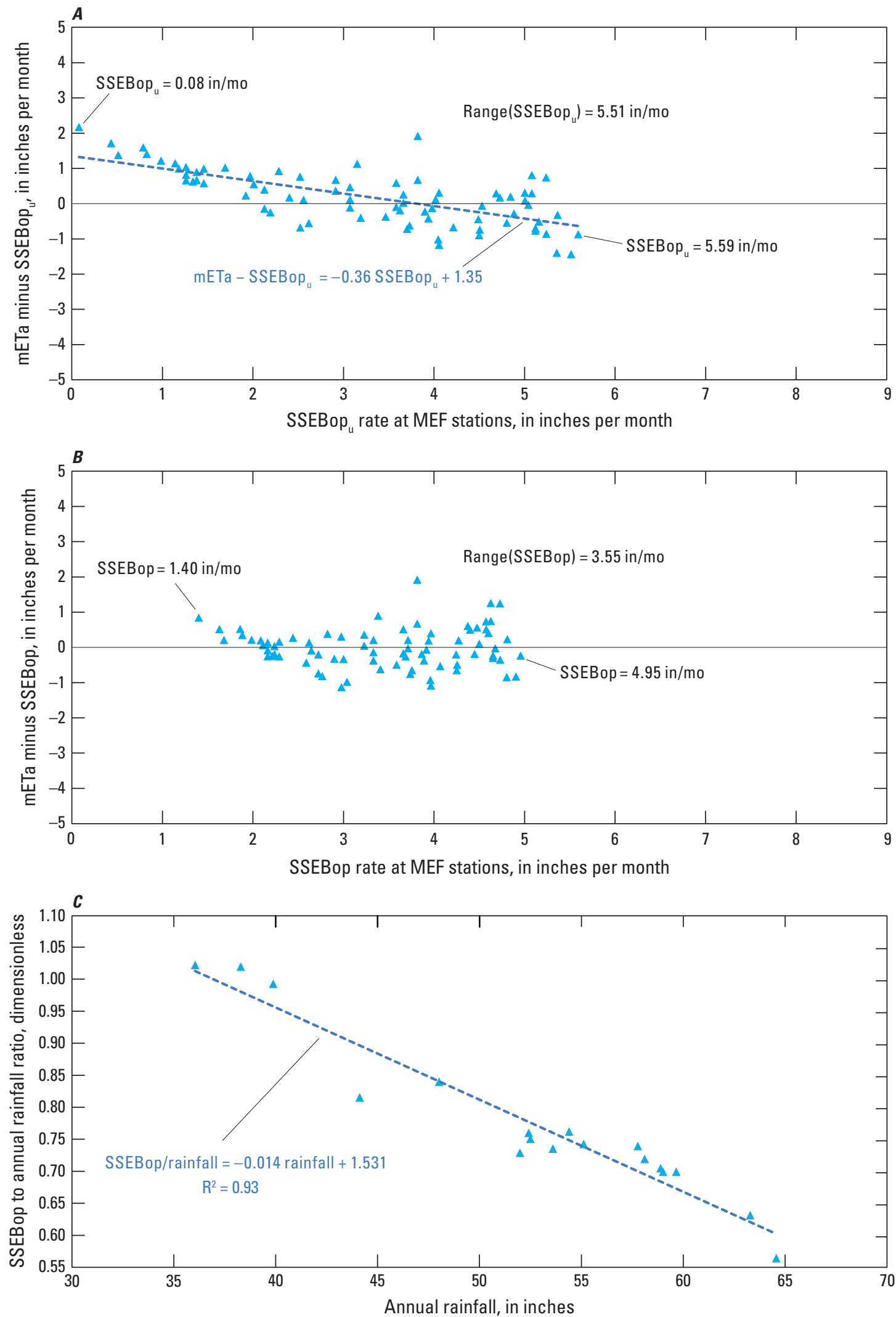

Figure 16. $A$, Bias (mETa minus SSEBop rate) versus SSEBop $\mathrm{p}_{\mathrm{u}}$ rates, $B$, residuals (mETa minus bias-corrected SSEBop rate) versus bias-corrected SSEBop rates, and $C$, bias-corrected annual SSEBop rate to annual rainfall ratio versus annual average rainfall at locations of micrometeorological stations in land-use type of agriculture. [mETa, actual evapotranspiration computed by using micrometeorological station data; SSEBop ${ }_{u}$, uncorrected Operational Simplified Surface Energy Balance; SSEBop, bias-corrected Operational Simplified Surface Energy Balance; ET, evapotranspiration; in/mo, inches per month] 

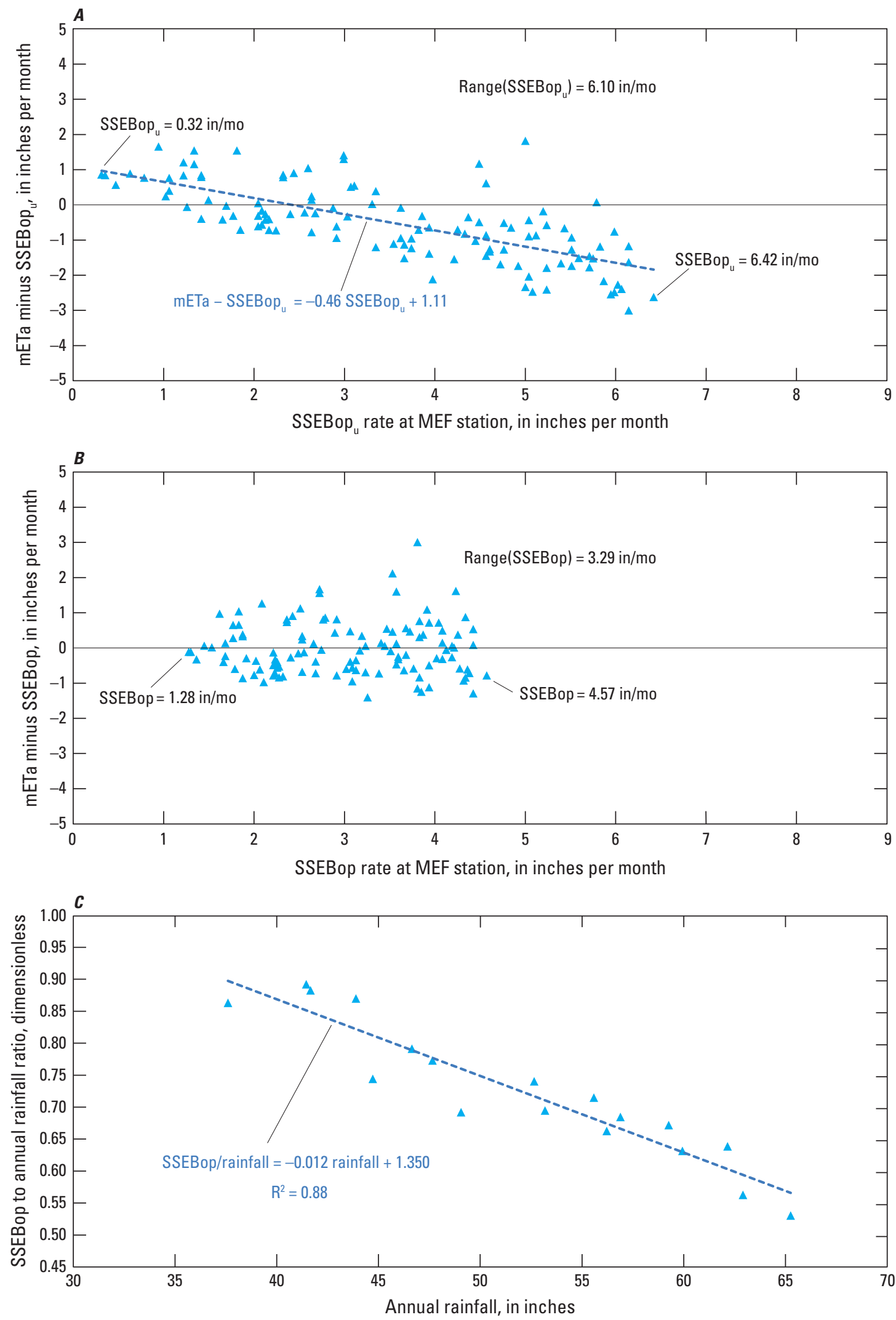

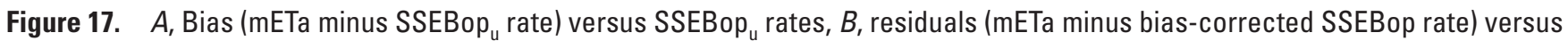
bias-corrected SSEBop rates, and $C$, bias-corrected annual SSEBop rate to annual rainfall ratio versus annual rainfall at locations of micrometeorological station in land-use type of forest. [mETa, actual evapotranspiration computed by using micrometeorological station data; SSEBop u $_{\text {, }}$ uncorrected Operational Simplified Surface Energy Balance; SSEBop, Operational Simplified Surface Energy Balance; ET, evapotranspiration; in/mo, inches per month] 

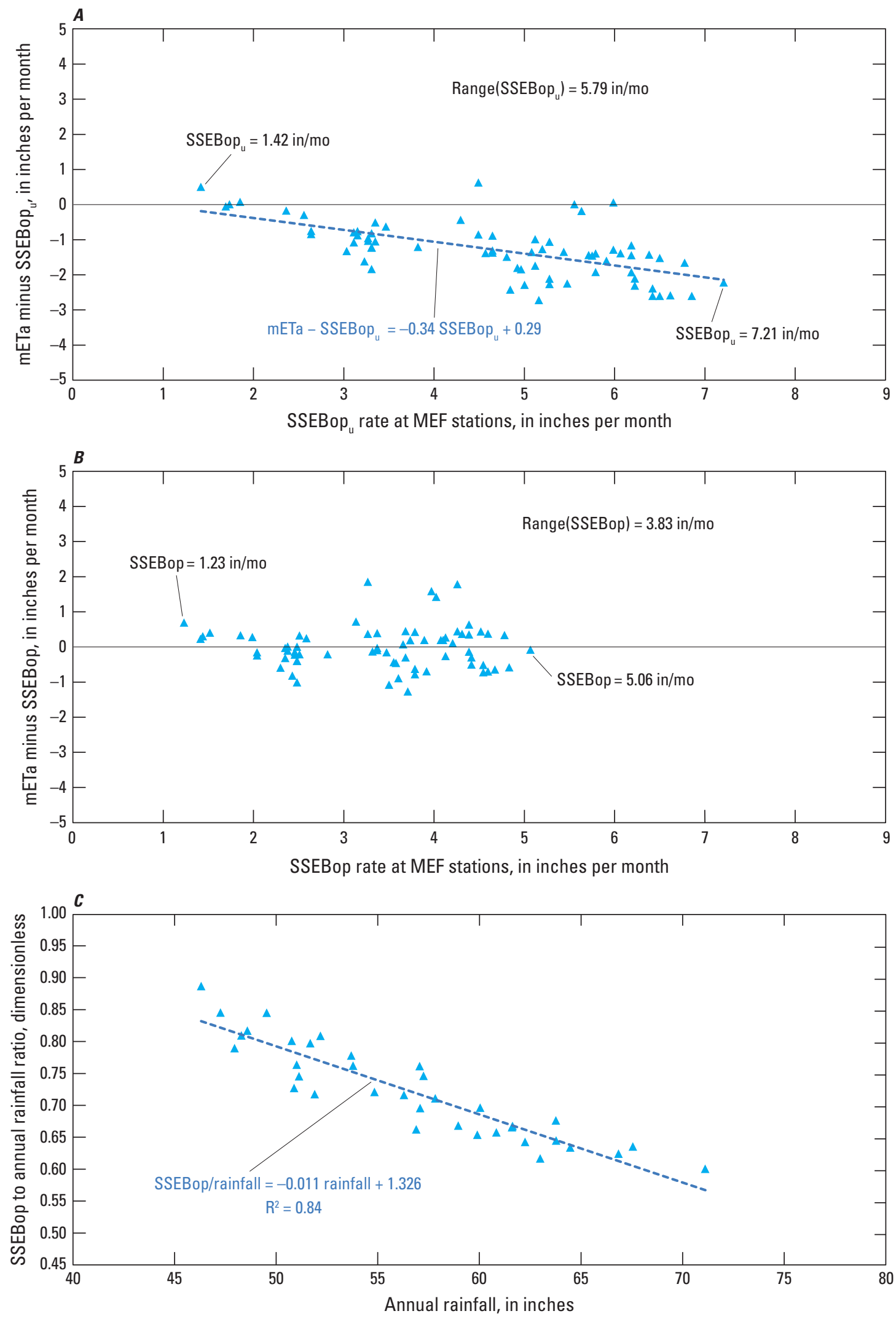

Figure 18. $A$, Bias (mETa minus SSEBop rate) versus SSEBop rates, $B$, residuals (mETa minus bias-corrected SSEBop rate) versus bias-corrected SSEBop rates, and $C$, bias-corrected annual SSEBop rate to annual rainfall ratio versus annual average rainfall at locations of micrometeorological stations in land-use type of forested wetland with low to medium canopy density. [mETa, actual evapotranspiration computed by using micrometeorological station data; SSEBop $_{u^{\prime}}$ uncorrected Operational Simplified Surface Energy Balance; SSEBop, Operational Simplified Surface Energy Balance; ET, evapotranspiration; in/mo, inches per month] 

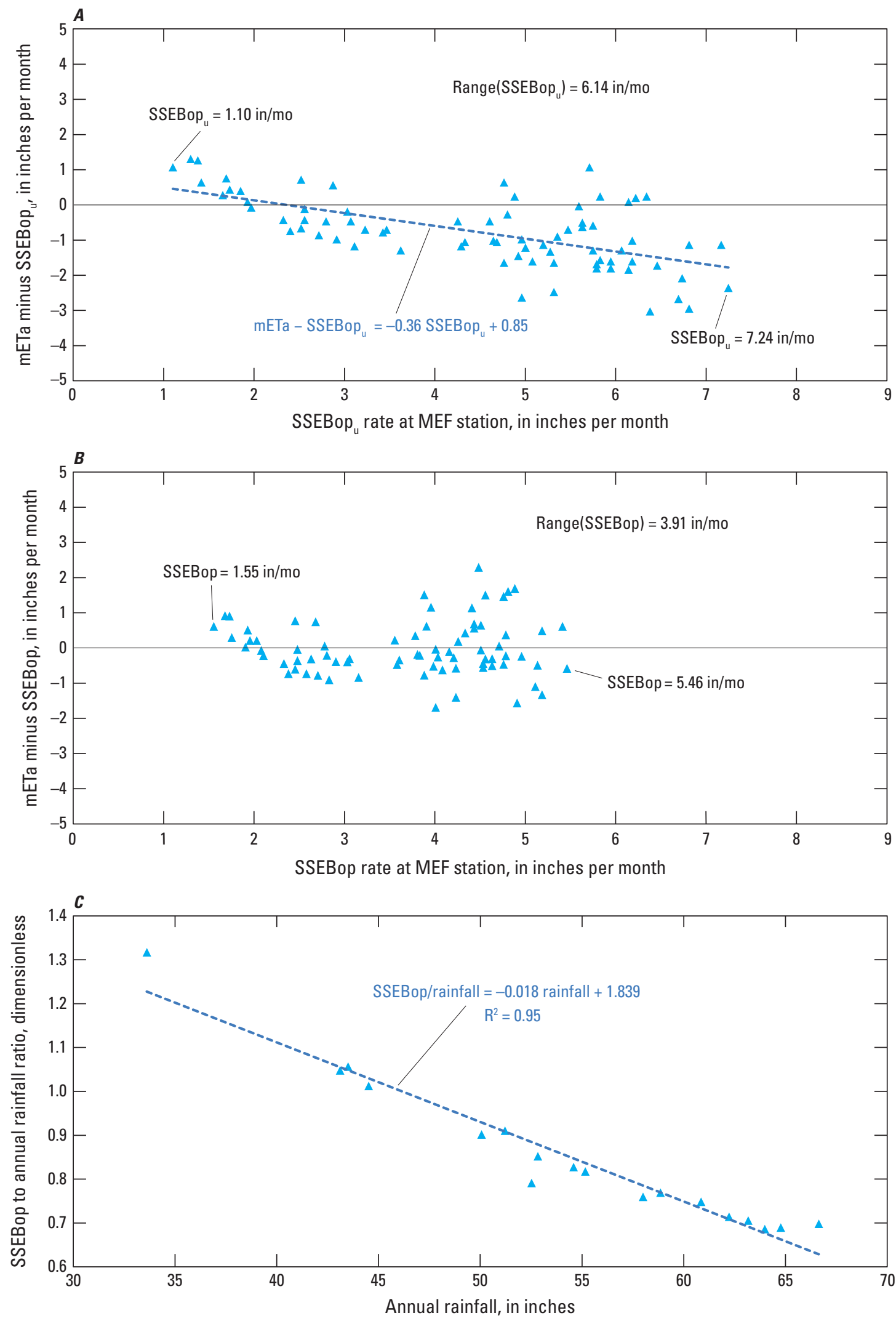

Figure 19. $A$, Bias (mETa minus SSEBop $p_{u}$ rate) versus SSEBop $p_{u}$ rates, $B$, residuals (mETa minus bias-corrected SSEBop rate) versus bias-corrected SSEBop rates, and $C$, bias-corrected annual SSEBop rate to annual rainfall ratio versus annual rainfall at locations of micrometeorological station in land-use type of forested wetland with high canopy density. [mETa, actual evapotranspiration computed by using micrometeorological station data; SSEBop $_{u}$, uncorrected Operational Simplified Surface Energy Balance; SSEBop, Operational Simplified Surface Energy Balance; ET, evapotranspiration; in/mo, inches per month] 

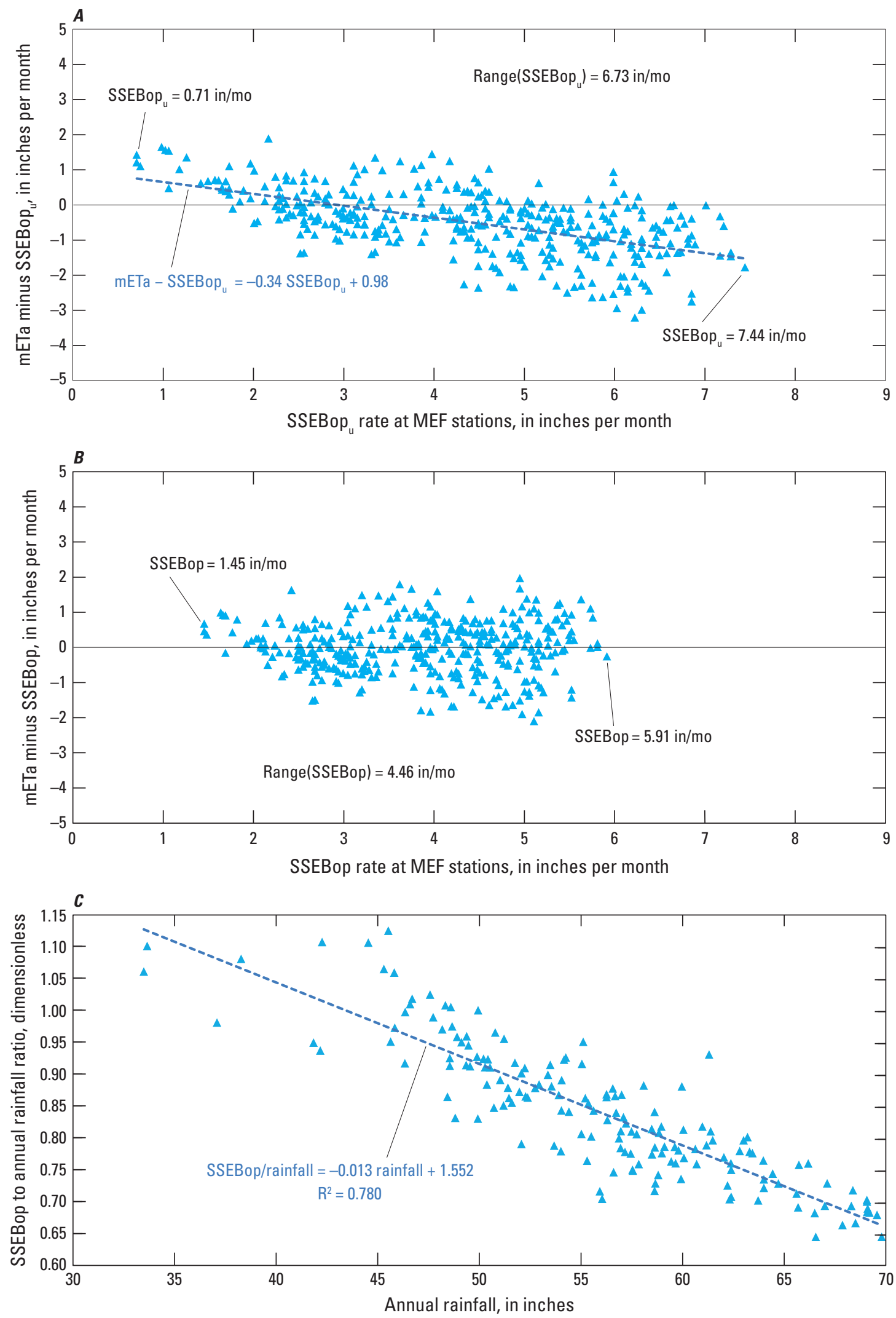

Figure 20. A, Bias (mETa minus SSEBop ${ }_{u}$ rate) versus SSEBop $p_{u}$ rates, $B$, residuals (mETa minus bias-corrected SSEBop rate) versus bias-corrected SSEBop rates, and $C$, bias-corrected annual SSEBop rate to annual rainfall ratio versus annual average rainfall at locations of meteorological stations in land-use type of marsh. [mETa, actual evapotranspiration computed by using micrometeorological station data; SSEBop ${ }_{u}$ uncorrected Operational Simplified Surface Energy Balance; SSEBop, Operational Simplified Surface Energy Balance; ET, evapotranspiration; in/mo, inches per month] 

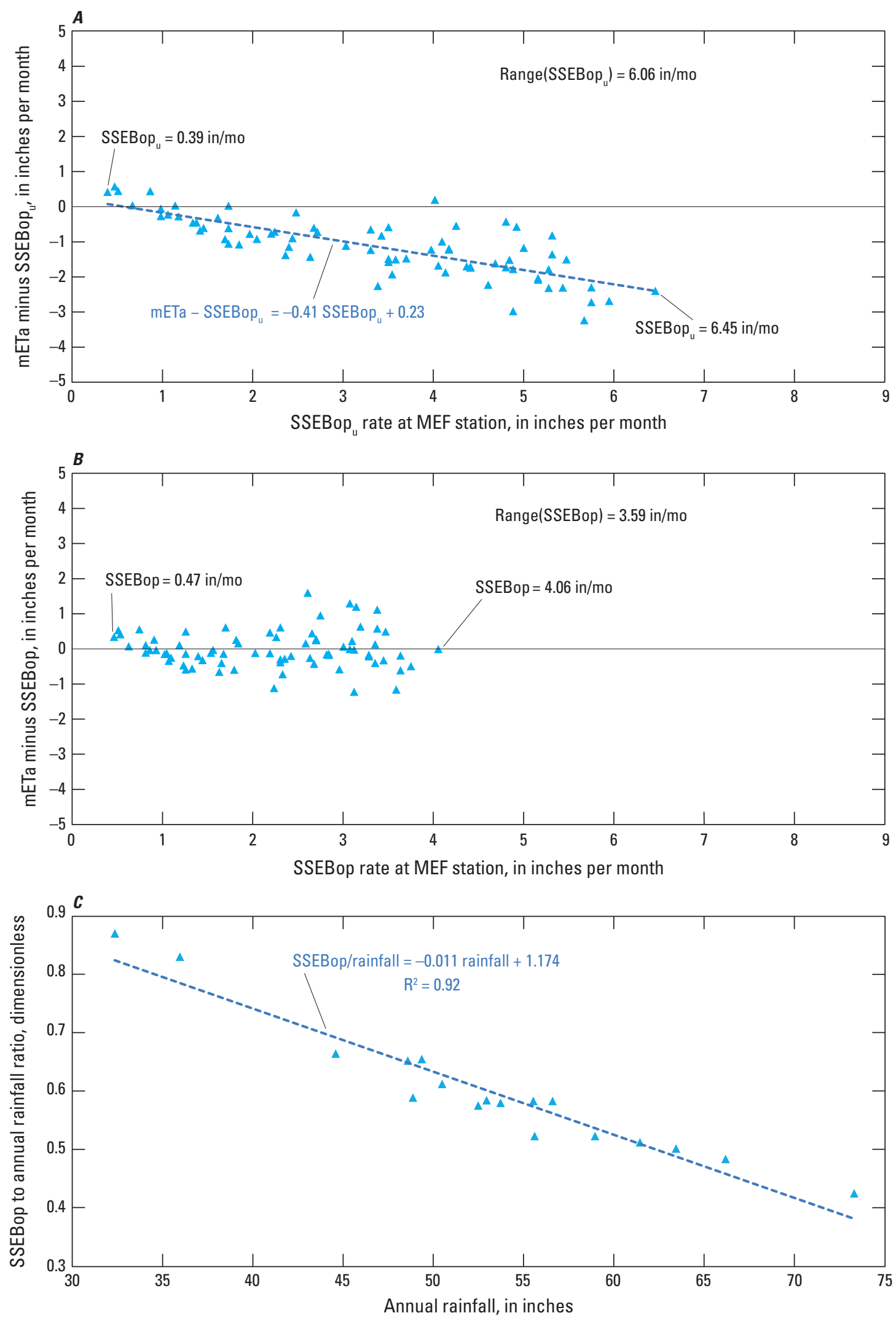

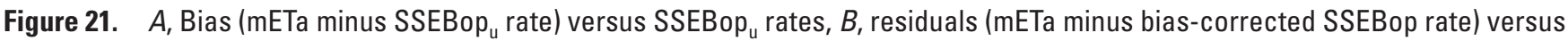
bias-corrected SSEBop rates, and $C$, bias-corrected annual SSEBop rate to annual rainfall ratio versus annual rainfall for location of micrometeorological station in the land-use type of deep-water-table pasture. [mETa, actual evapotranspiration computed by using micrometeorological station data; SSEBop $_{u}$, uncorrected Operational Simplified Surface Energy Balance; SSEBop, Operational Simplified Surface Energy Balance; ET, evapotranspiration; in/mo, inches per month] 

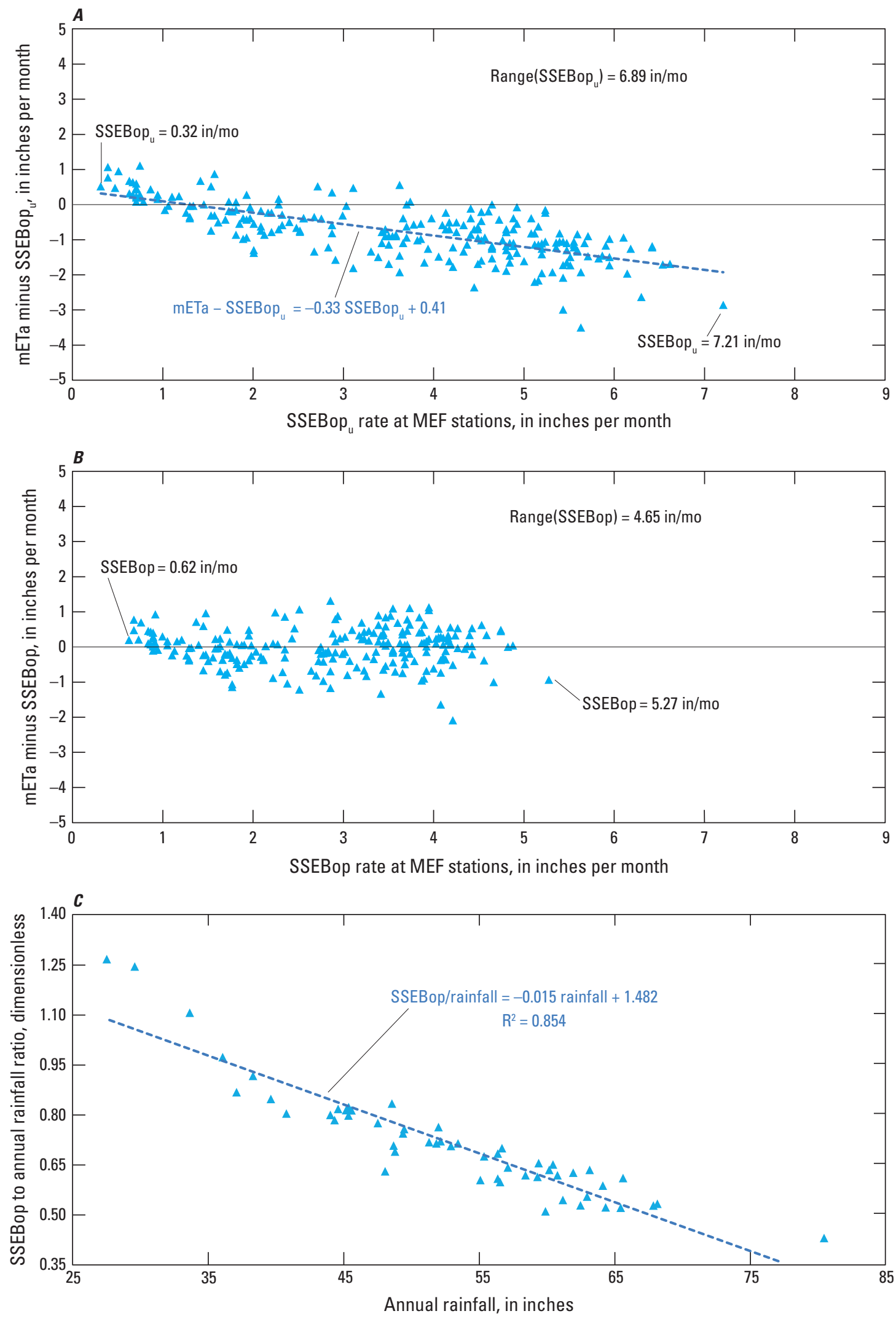

Figure 22. $A$, Bias (mETa minus SSEBop ${ }_{u}$ rate) versus SSEBop ${ }_{u}$ rates, $B$, residuals ( $m E T a$ minus bias-corrected SSEBop rate) versus bias-corrected SSEBop rates, and $C$, bias-corrected annual SSEBop rate to annual rainfall ratio versus annual rainfall at locations of micrometeorological stations in the land-use type of shallow-water-table pasture. [mETa, actual evapotranspiration computed by using micrometeorological station data; SSEBop $_{u}$, uncorrected Operational Simplified Surface Energy Balance; SSEBop, Operational Simplified Surface Energy Balance; ET, evapotranspiration; in/mo, inches per month] 

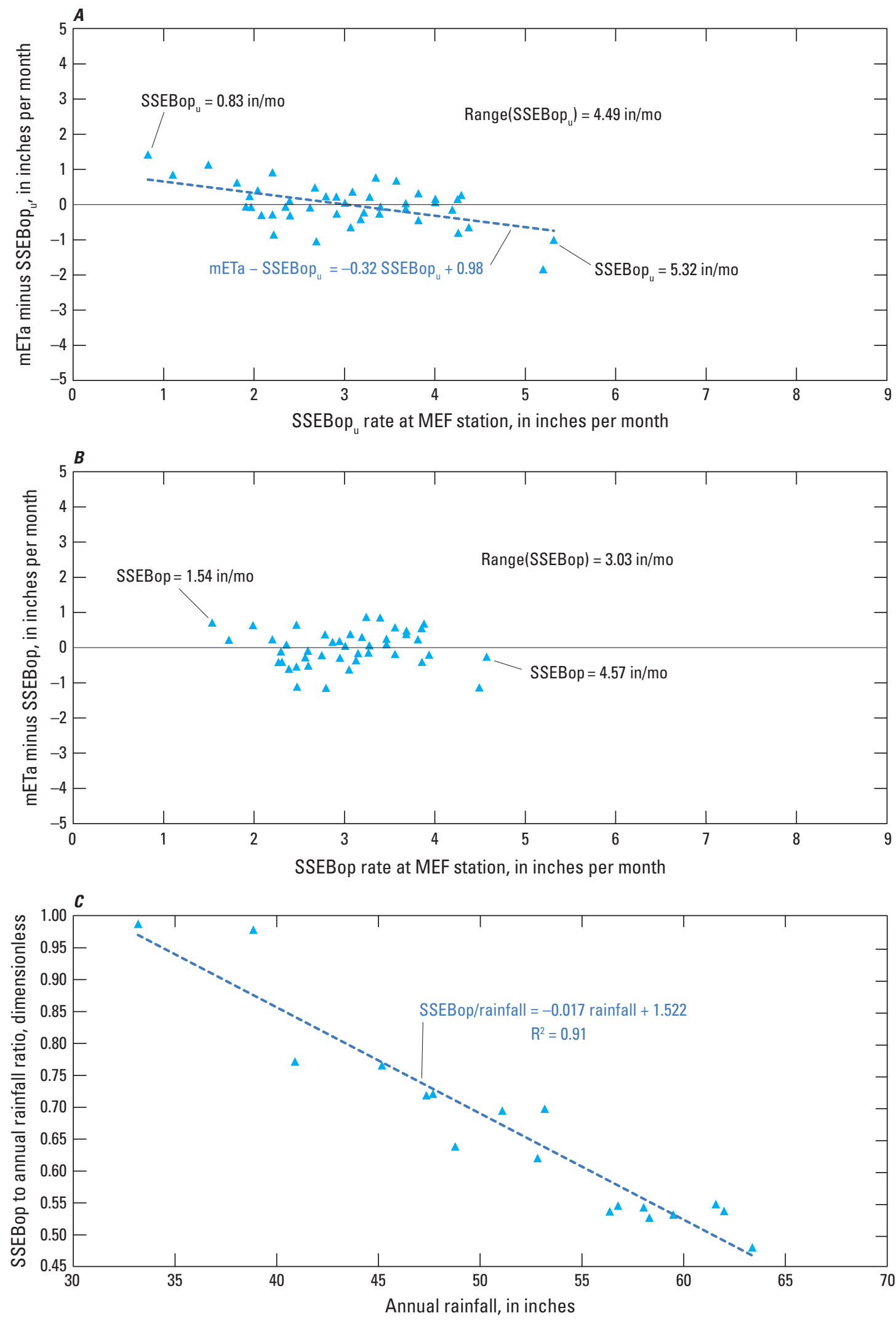

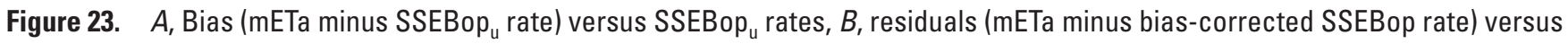
bias-corrected SSEBop rates, and $C$, bias-corrected annual SSEBop rate to annual rainfall ratio versus annual rainfall at location of micrometeorological station in the land-use type of urban. [mETa, actual evapotranspiration computed by using micrometeorological station data; SSEBop ${ }_{u}$, uncorrected Operational Simplified Surface Energy Balance; SSEBop, Operational Simplified Surface Energy Balance; ET, evapotranspiration; in/mo, inches per month] 

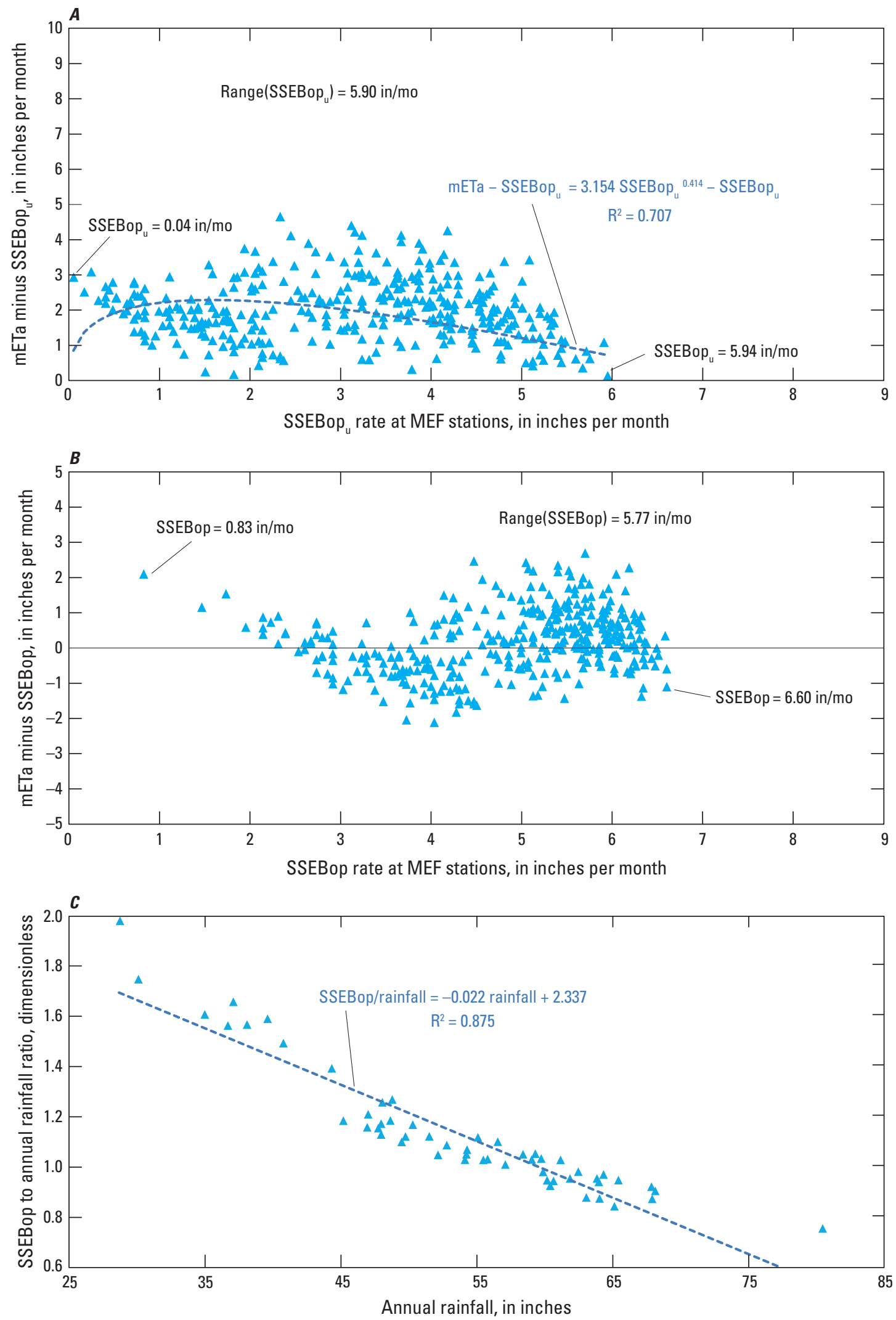

Figure 24. $A$, Bias (mETa minus SSEBop ${ }_{u}$ rate) versus SSEBop $p_{u}$ rates, $B$, residuals (mETa minus bias-corrected SSEBop rate) versus bias-corrected SSEBop rates, and $C$, bias-corrected annual SSEBop rate to annual rainfall ratio versus annual average rainfall at locations of micrometeorological stations in land-use type of open-water surface. [mETa, actual evapotranspiration computed by using micrometeorological station data; SSEBop $_{u}$, uncorrected Operational Simplified Surface Energy Balance; SSEBop, Operational Simplified Surface Energy Balance; ET, evapotranspiration; in/mo, inches per month] 
Table 14. Basins, streamgages at basin outlets, basin areas, average annual actual evapotranspiration (ETa) rates over the 2000-17 period for the wbETa, land use, SSEBop,

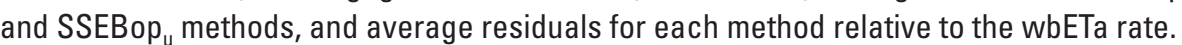

[POR, period of record of measurements of hydrologic terms in the water-balance method; wbETa, calculated actual evapotranspiration (ETa) rate from the water-balance method for the basin; luETa, calculated

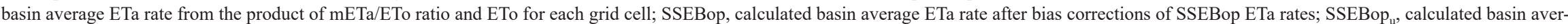

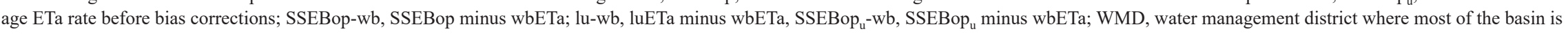
located; No., unique basin number assigned in figure 2; PER-Res, percentage of residual relative to wbETa rates; NWFWMD, Northwest Florida Water Management District; SFWMD, South Florida Water Management District; NG, no outflow; SJRWMD, St. Johns River Water Management District; SJR, St. Johns River; SRWMD, Suwannee River Water Management District; SWFWMD, Southwest Florida Water Management District; SR, State Road; Blvd., boulevard; TBW, Tampa Bay Water; NA, not applicable; RMSE, root-mean-square error calculated over 55 basins; Average, simple mean calculated over 55 basins; Basin area is in square miles; all ETa rates are in inches per year]

\begin{tabular}{|c|c|c|c|c|c|c|c|c|c|c|c|c|c|}
\hline Basin name & $\begin{array}{l}\text { Streamgage(s) } \\
\text { at basin outlet }\end{array}$ & Basin area & POR & wbETa & luETa & SSEBop & SSEBop $_{\mathrm{u}}$ & $\begin{array}{c}\text { SSEBop- } \\
\text { wb }\end{array}$ & lu-wb & $\begin{array}{l}\text { SSEBop }_{u}- \\
\text { wb }\end{array}$ & WMD & $\begin{array}{c}\text { Basin } \\
\text { No. } \\
\text { (fig. 2) }\end{array}$ & $\begin{array}{l}\text { PER- } \\
\text { Res }\end{array}$ \\
\hline Lower Ochlockonee River & $\begin{array}{r}02330150, \\
02327100\end{array}$ & $1,188.884$ & $2000-2017$ & 39.56 & 36.88 & 37.94 & 44.20 & -1.62 & -2.68 & 4.64 & NWFWMD & 1 & -4.10 \\
\hline Apalachicola-Chipola & 02359170 & $2,043.475$ & $2000-2017$ & 38.41 & 35.74 & 36.41 & 41.98 & -2.00 & -2.67 & 3.57 & NWFWMD & 2 & -5.21 \\
\hline Lower Choctawhatchee River & $\begin{array}{r}02366500 \\
02366650\end{array}$ & $1,341.080$ & $2000-2017$ & 38.01 & 35.24 & 36.49 & 42.19 & -1.52 & -2.77 & 4.18 & NWFWMD & 3 & -4.00 \\
\hline Yellow River & 02369600 & $1,360.291$ & 2002-2017 & 35.31 & 35.82 & 34.83 & 40.11 & -0.48 & 0.51 & 4.80 & NWFWMD & 4 & -1.36 \\
\hline Escambia-Perdido & $\begin{array}{r}02376500 \\
02376033\end{array}$ & 722.670 & $2000-2017$ & 35.75 & 36.95 & 35.16 & 40.43 & -0.59 & 1.20 & 4.68 & NWFWMD & 5 & -1.65 \\
\hline Boggy Creek Swamp & 02262900 & 83.205 & $2003-2017$ & 37.20 & 38.32 & 35.36 & 30.87 & -1.84 & 1.12 & -6.33 & SFWMD & 6 & -4.95 \\
\hline C-139 & NG & 263.012 & 2004-2017 & 35.56 & 38.92 & 34.95 & 38.20 & -0.61 & 3.36 & 2.64 & SFWMD & 7 & -1.72 \\
\hline Caloosahatchee & 02292900 & 829.602 & $2000-2015$ & 38.02 & 38.16 & 36.33 & 39.23 & -1.69 & 0.14 & 1.21 & SFWMD & 8 & -4.45 \\
\hline Reedy-Shingle Creek & $\begin{array}{r}02264495 \\
02266500\end{array}$ & 256.302 & $2001-2017$ & 38.38 & 38.60 & 37.55 & 37.96 & -0.83 & 0.22 & -0.42 & SFWMD & 9 & -2.16 \\
\hline Tidal South & 02293055 & 85.535 & 2008-2012 & 33.47 & 37.13 & 35.26 & 34.62 & 1.79 & 3.66 & 1.15 & SFWMD & 10 & 5.35 \\
\hline Fort Drum Creek & 02231342 & 45.084 & 2011-2017 & 36.08 & 36.87 & 34.36 & 40.44 & -1.72 & 0.79 & 4.36 & SJRWMD & 11 & -4.77 \\
\hline Blue Cypress Creek & 02231396 & 105.295 & $2003-2017$ & 37.58 & 36.46 & 35.18 & 42.13 & -2.40 & -1.12 & 4.55 & SJRWMD & 12 & -6.39 \\
\hline St. Johns River at Melbourne & 02232000 & 939.818 & $2001-2017$ & 42.48 & 39.10 & 40.01 & 45.86 & -2.47 & -3.38 & 3.38 & SJRWMD & 13 & -5.81 \\
\hline Pennywash Creek & 02232155 & 19.429 & 2003-2017 & 36.80 & 35.83 & 34.24 & 41.08 & -2.56 & -0.97 & 4.28 & SJRWMD & 14 & -6.96 \\
\hline Apopka Beauclair Canal & 02237700 & 196.101 & $2000-2008$ & 45.90 & 42.76 & 45.83 & 43.38 & -0.07 & -3.14 & -2.52 & SJRWMD & 15 & -0.15 \\
\hline Ocklawaha Moss Bluff & 02238500 & 842.514 & 2009-2017 & 43.93 & 41.59 & 42.34 & 40.85 & -1.59 & -2.34 & -3.08 & SJRWMD & 16 & -3.62 \\
\hline Orange Creek at Orange Spring & 02243000 & 522.914 & $2000-2017$ & 40.97 & 36.90 & 39.09 & 43.26 & -1.88 & -4.07 & 2.29 & SJRWMD & 17 & -4.59 \\
\hline St. Johns River at Buffalo Bluff & 02244040 & $5,895.788$ & $2000-2017$ & 41.25 & 38.74 & 40.24 & 43.86 & -1.01 & -2.51 & 2.61 & SJRWMD & 18 & -2.45 \\
\hline Haw Creek ab Russell Landing & 02244333 & 189.225 & 2011-2017 & 39.73 & 37.17 & 36.91 & 42.96 & -2.82 & -2.56 & 3.23 & SJRWMD & 19 & -7.10 \\
\hline Tomoka River & 02247510 & 62.721 & 2004-2017 & 39.11 & 39.59 & 37.77 & 43.43 & -1.34 & 0.48 & 4.32 & SJRWMD & 20 & -3.43 \\
\hline Turkey Creek & 02250030 & 94.582 & 2009-2017 & 36.58 & 37.33 & 36.01 & 36.93 & -0.57 & 0.75 & 0.35 & SJRWMD & 21 & -1.56 \\
\hline St. Johns River near Christmas & 02232500 & $1,490.445$ & $2001-2017$ & 40.67 & 39.25 & 39.91 & 45.59 & -0.76 & -1.42 & 4.92 & SJRWMD & 22 & -1.87 \\
\hline
\end{tabular}


Table 14. Basins, streamgages at basin outlets, basin areas, average annual actual evapotranspiration (ETa) rates over the 2000-17 period for the wbETa, land use, SSEBop, and SSEBop methods, and average residuals for each method relative to the wbETa rate.-Continued

[POR, period of record of measurements of hydrologic terms in the water-balance method; wbETa, calculated actual evapotranspiration (ETa) rate from the water-balance method for the basin; luETa, calculated basin average ETa rate from the product of $\mathrm{mETa} / \mathrm{ETo}$ ratio and ETo for each grid cell; SSEBop, calculated basin average ETa rate after bias corrections of SSEBop ETa rates; SSEBop ${ }_{u}$, calculated basin aver-

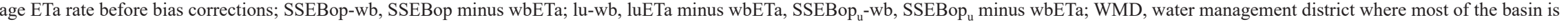
located; No., unique basin number assigned in figure 2; PER-Res, percentage of residual relative to wbETa rates; NWFWMD, Northwest Florida Water Management District; SFWMD, South Florida Water Management District; NG, no outflow; SJRWMD, St. Johns River Water Management District; SJR, St. Johns River; SRWMD, Suwannee River Water Management District; SWFWMD, Southwest Florida Water Management District; SR, State Road; Blvd., boulevard; TBW, Tampa Bay Water; NA, not applicable; RMSE, root-mean-square error calculated over 55 basins; Average, simple mean calculated over 55 basins; Basin area is in square miles; all ETa rates are in inches per year]

\begin{tabular}{|c|c|c|c|c|c|c|c|c|c|c|c|c|c|}
\hline Basin name & $\begin{array}{l}\text { Streamgage(s) } \\
\text { at basin outlet }\end{array}$ & Basin area & POR & wbETa & luETa & $\begin{array}{l}\text { SSE- } \\
\text { Bop }\end{array}$ & $\begin{array}{l}\text { SSE- } \\
\text { Bop }_{u}\end{array}$ & $\begin{array}{l}\text { SSEBop- } \\
\text { wb }\end{array}$ & lu-wb & $\begin{array}{c}\text { SSE- } \\
\text { Bop }_{u}-w b\end{array}$ & WMD & $\begin{array}{c}\text { Basin } \\
\text { No. } \\
\text { (fig. 2) }\end{array}$ & $\begin{array}{l}\text { PER- } \\
\text { Res }\end{array}$ \\
\hline Econlockhatchee River & 02233484 & 265.952 & 2001-2017 & 36.13 & 36.99 & 36.24 & 38.30 & 0.11 & 0.86 & 2.17 & SJRWMD & 23 & 0.30 \\
\hline Wekiva River & 02235000 & 113.835 & 2003-2017 & 38.18 & 38.61 & 37.70 & 39.00 & -0.48 & 0.43 & 0.82 & SJRWMD & 24 & -1.26 \\
\hline Deep Creek & 02245260 & 52.794 & 2013-2017 & 37.95 & 35.94 & 38.13 & 40.93 & 0.18 & -2.01 & 2.98 & SJRWMD & 25 & 0.47 \\
\hline Black Creek & 02245500 & 140.137 & $2001-2017$ & 36.24 & 35.98 & 36.14 & 41.73 & -0.10 & -0.26 & 5.49 & SJRWMD & 26 & -0.28 \\
\hline North Fork Black Creek & 02246000 & 149.492 & 2004-2017 & 36.87 & 35.81 & 35.93 & 41.24 & -0.94 & -1.06 & 4.37 & SJRWMD & 27 & -2.55 \\
\hline Eau Gallie River & 02249007 & 4.684 & 2009-2017 & 30.48 & 36.97 & 35.77 & 14.37 & 5.29 & 6.49 & -16.11 & SJRWMD & 28 & 17.36 \\
\hline $\begin{array}{l}\text { South Prong at St. Sebastian } \\
\text { River }\end{array}$ & 02251000 & 56.277 & 2009-2017 & 36.96 & 36.78 & 36.24 & 41.14 & -0.72 & -0.18 & 4.18 & SJRWMD & 29 & -1.95 \\
\hline Alapaha & 02317620 & $1,671.834$ & $2000-2017$ & 37.48 & 41.23 & 35.66 & 39.76 & -1.82 & 3.75 & 2.28 & SRWMD & 30 & -4.86 \\
\hline Withlacoochee-SRWMD & 02319394 & $2,390.020$ & 2000-2017 & 39.16 & 40.81 & 35.52 & 36.85 & -3.64 & 1.65 & -2.31 & SRWMD & 31 & -9.30 \\
\hline Upper Suwannee River & 02319500 & $2,789.673$ & $2000-2017$ & 40.18 & 38.75 & 37.11 & 46.42 & -3.07 & -1.43 & 6.24 & SRWMD & 32 & -7.64 \\
\hline Santa Fe River & 02322800 & $1,380.226$ & $2000-2017$ & 36.48 & 35.34 & 36.02 & 40.97 & -0.46 & -1.14 & 4.49 & SRWMD & 33 & -1.26 \\
\hline Suwannee River & 02323500 & $9,533.277$ & $2000-2017$ & 39.70 & 38.72 & 36.03 & 41.48 & -3.67 & -0.98 & 1.78 & SRWMD & 34 & -9.24 \\
\hline Aucilla & 02326500 & 749.594 & $2000-2017$ & 39.71 & 37.56 & 37.41 & 43.40 & -2.30 & -2.15 & 3.69 & SRWMD & 35 & -5.79 \\
\hline Peace Creek Canal-Brush Lake & 02293987 & 171.568 & $2000-2017$ & 40.43 & 40.22 & 40.52 & 39.54 & 0.09 & -0.21 & -0.89 & SWFWMD & 36 & 0.22 \\
\hline $\begin{array}{l}\text { Saddle Creek at SR } 542 \text { near } \\
\text { Lakeland }\end{array}$ & 02294217 & 59.381 & $2000-2017$ & 39.86 & 38.88 & 40.28 & 42.38 & 0.42 & -0.98 & 2.52 & SWFWMD & 37 & 1.05 \\
\hline $\begin{array}{l}\text { Joshua Creek at Nocatee-Honey } \\
\text { Run }\end{array}$ & 02297100 & 121.003 & $2000-2017$ & 35.45 & 37.40 & 34.23 & 36.87 & -1.22 & 1.95 & 1.42 & SWFWMD & 38 & -3.44 \\
\hline Prairie Creek at Fort Ogden & 02298123 & 245.561 & $2000-2017$ & 36.77 & 38.19 & 35.50 & 38.80 & -1.27 & 1.42 & 2.03 & SWFWMD & 39 & -3.45 \\
\hline Shell Creek nr Punta Gorda & 02298202 & 133.915 & $2000-2017$ & 37.57 & 37.95 & 34.40 & 37.95 & -3.17 & 0.38 & 0.38 & SWFWMD & 40 & -8.44 \\
\hline Myakka River near Sarasota & 02298830 & 227.223 & $2000-2017$ & 36.14 & 36.14 & 35.24 & 40.46 & -0.90 & 0.00 & 4.32 & SWFWMD & 41 & -2.49 \\
\hline Big Slough at Tropicaire Blvd & 02299450 & 73.665 & 2001-2017 & 38.44 & 36.16 & 35.35 & 41.29 & -3.09 & -2.28 & 2.85 & SWFWMD & 42 & -8.04 \\
\hline Manatee River at Fort Hamer & 02300021 & 206.318 & 2006-2016 & 35.96 & 37.33 & 34.60 & 37.81 & -1.36 & 1.37 & 1.85 & SWFWMD & 43 & -3.78 \\
\hline $\begin{array}{l}\text { Jumper Creek Canal near } \\
\text { Bushnell }\end{array}$ & 02312640 & 39.819 & $2012-2017$ & 34.14 & 34.69 & 31.89 & 34.70 & -2.25 & 0.55 & 0.56 & SWFWMD & 44 & -6.59 \\
\hline
\end{tabular}


Table 14. Basins, streamgages at basin outlets, basin areas, average annual actual evapotranspiration (ETa) rates over the 2000-17 period for the wbETa, land use, SSEBop, and SSEBop ${ }_{u}$ methods, and average residuals for each method relative to the wbETa rate.-Continued

[POR, period of record of measurements of hydrologic terms in the water-balance method; wbETa, calculated actual evapotranspiration (ETa) rate from the water-balance method for the basin; luETa, calculated basin average ETa rate from the product of $\mathrm{mETa} / \mathrm{ETo}$ ratio and ETo for each grid cell; SSEBop, calculated basin average ETa rate after bias corrections of SSEBop ETa rates; SSEBop

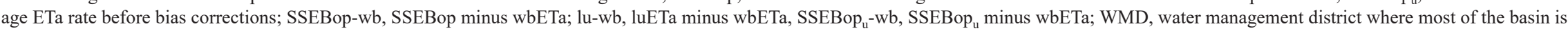
located; No., unique basin number assigned in figure 2; PER-Res, percentage of residual relative to wbETa rates; NWFWMD, Northwest Florida Water Management District; SFWMD, South Florida Water Management District; NG, no outflow; SJRWMD, St. Johns River Water Management District; SJR, St. Johns River; SRWMD, Suwannee River Water Management District; SWFWMD, Southwest Florida Water Management District; SR, State Road; Blvd., boulevard; TBW, Tampa Bay Water; NA, not applicable; RMSE, root-mean-square error calculated over 55 basins; Average, simple mean calculated over 55 basins; Basin area is in square miles; all ETa rates are in inches per year]

\begin{tabular}{|c|c|c|c|c|c|c|c|c|c|c|c|c|c|}
\hline Basin name & $\begin{array}{l}\text { Streamgage }(s) \\
\text { at basin outlet }\end{array}$ & Basin area & POR & wbETa & luETa & $\begin{array}{l}\text { SSE- } \\
\text { Bop }\end{array}$ & $\begin{array}{l}\text { SSE- } \\
\text { Bop }_{u}\end{array}$ & $\begin{array}{l}\text { SSEBop- } \\
\text { wb }\end{array}$ & lu-wb & $\begin{array}{c}\text { SSE- } \\
\text { Bop }_{u}-w b\end{array}$ & WMD & $\begin{array}{c}\text { Basin } \\
\text { No. } \\
\text { (fig. 2) }\end{array}$ & $\begin{array}{l}\text { PER- } \\
\text { Res }\end{array}$ \\
\hline Panasoffkee Lake Basin & 02312700 & 79.386 & $2000-2017$ & 36.67 & 35.38 & 36.65 & 41.65 & -0.02 & -1.29 & 4.98 & SWFWMD & 45 & -0.05 \\
\hline $\begin{array}{l}\text { Withlacoochee River near } \\
\text { Holder }\end{array}$ & 02313000 & $1,789.420$ & 2004-2017 & 38.79 & 36.27 & 36.41 & 42.09 & -2.38 & -2.52 & 3.30 & SWFWMD & 46 & -6.14 \\
\hline $\begin{array}{l}\text { Withlacoochee River Inglis \& } \\
\text { Bypass }\end{array}$ & 02313230 & $2,049.615$ & 2004-2017 & 37.74 & 36.06 & 36.18 & 41.46 & -1.56 & -1.68 & 3.72 & SWFWMD & 47 & -4.13 \\
\hline Little Manatee River & 02300500 & 151.595 & $2000-2017$ & 35.16 & 37.26 & 33.78 & 37.04 & -1.38 & 2.10 & 1.88 & TBW & 48 & -3.92 \\
\hline North Prong Alafia River & 02301000 & 136.032 & 2000-2017 & 36.53 & 36.15 & 35.04 & 39.66 & -1.49 & -0.38 & 3.13 & TBW & 49 & -4.08 \\
\hline South Prong Alafia River & 02301300 & 112.393 & 2000-2017 & 37.59 & 37.43 & 34.74 & 42.53 & -2.85 & -0.16 & 4.94 & TBW & 50 & -7.58 \\
\hline $\begin{array}{l}\text { Hillsborough River ab Crystal } \\
\text { Spring }\end{array}$ & 02301990 & 85.749 & $2000-2017$ & 38.27 & 34.78 & 36.08 & 41.46 & -2.19 & -3.49 & 3.19 & TBW & 51 & -5.72 \\
\hline Blackwater Creek near Knights & 02302500 & 98.616 & $2000-2017$ & 36.55 & 34.75 & 35.27 & 39.29 & -1.28 & -1.80 & 2.74 & TBW & 52 & -3.50 \\
\hline Cypress Creek and Trout Creek & 02303800 & 185.057 & 2000-2017 & 38.17 & 35.86 & 34.69 & 38.79 & -3.48 & -2.31 & 0.62 & TBW & 53 & -9.12 \\
\hline Sweetwater Creek near Tampa & 02306647 & 24.436 & $2000-2017$ & 36.61 & 36.18 & 34.65 & 29.27 & -1.96 & -0.43 & -7.34 & TBW & 54 & -5.35 \\
\hline \multirow[t]{3}{*}{ Anclote River near Elfers } & 02310000 & 69.597 & 2000-2017 & 35.43 & 35.92 & 33.92 & 38.57 & -1.51 & 0.49 & 3.14 & TBW & 55 & -4.26 \\
\hline & Average & 798.838 & NA & 37.79 & 37.38 & 36.46 & 39.76 & -1.33 & -0.41 & 1.97 & NA & NA & -3.41 \\
\hline & RMSE & NA & NA & NA & NA & NA & NA & 1.95 & 2.07 & 4.13 & NA & NA & NA \\
\hline
\end{tabular}




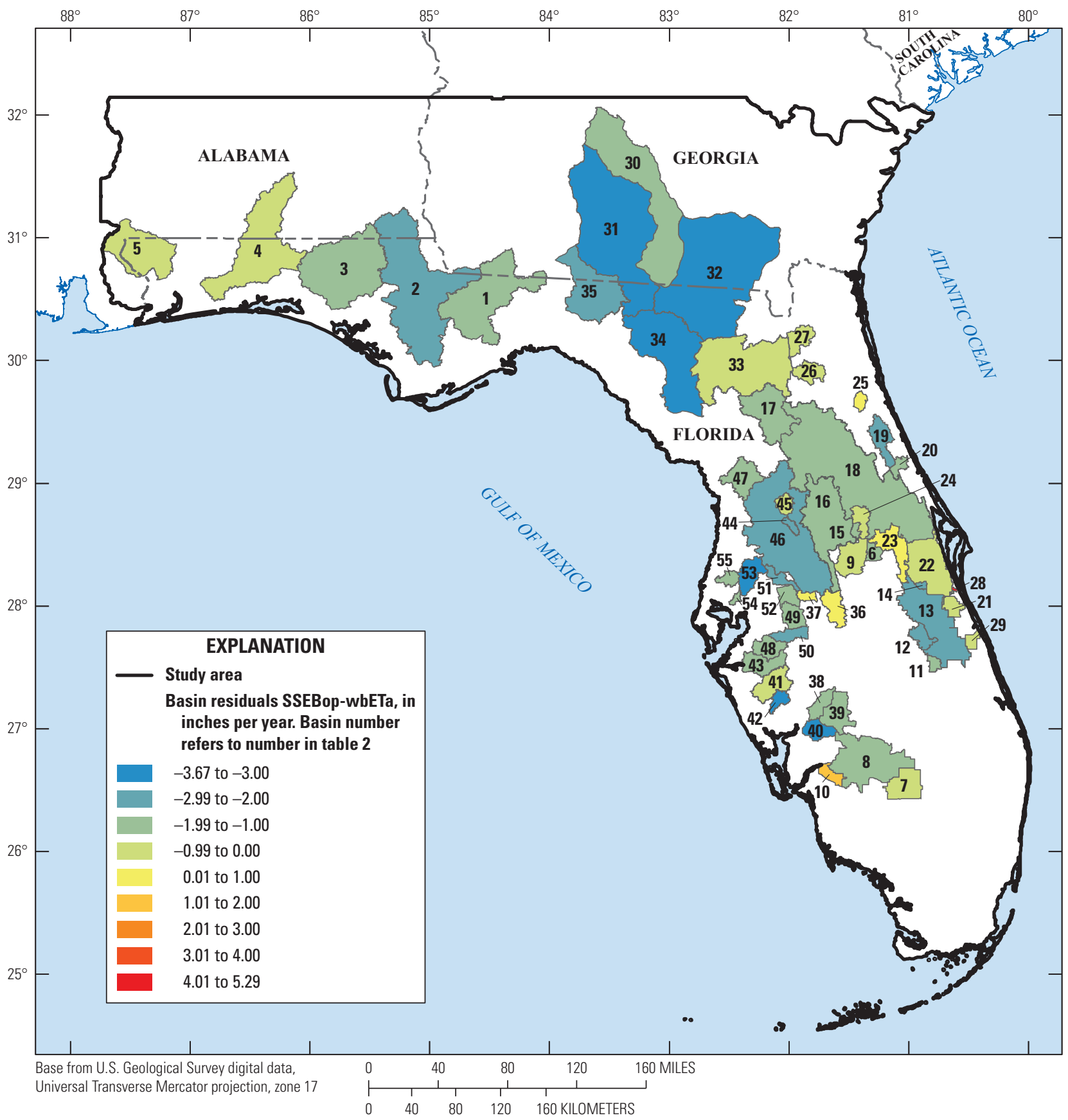

Figure 25. Spatial distribution of residuals in actual evapotranspiration (ETa) rates between the bias-corrected Operational Simplified Surface Energy Balance (SSEBop) and the water-balance methods for all selected basins in the study area. [wbETa, actual evapotranspiration calculated from the water-balance method]

areas. Differences in contributing areas between the surfacewater and groundwater basins require the estimation of flows through those boundaries that are not common to these two basin delineation types when applying the water-balance method. The lack of flow estimates through the lateral boundaries that make the surface-water basin and groundwater basin different may explain why the wbETa rates are higher than the SSEBop rates (table 14). For example, flows leaving the basin through the southern boundary of the Suwannee River
Basin (basin 34 in table 14, fig. 30) that are not measured at streamgage 02323500 because the groundwater basin may be different from the surface-water basin would result in an increase in net streamflow discharge (NetQ in eq. 10, fig. 10) and thus reduce wbETa rates.

The Upper Floridan aquifer was included in the control volume for these basins to reduce errors associated with delineating areas where the aquifer is confined or unconfined; however, additional error may have been introduced because 


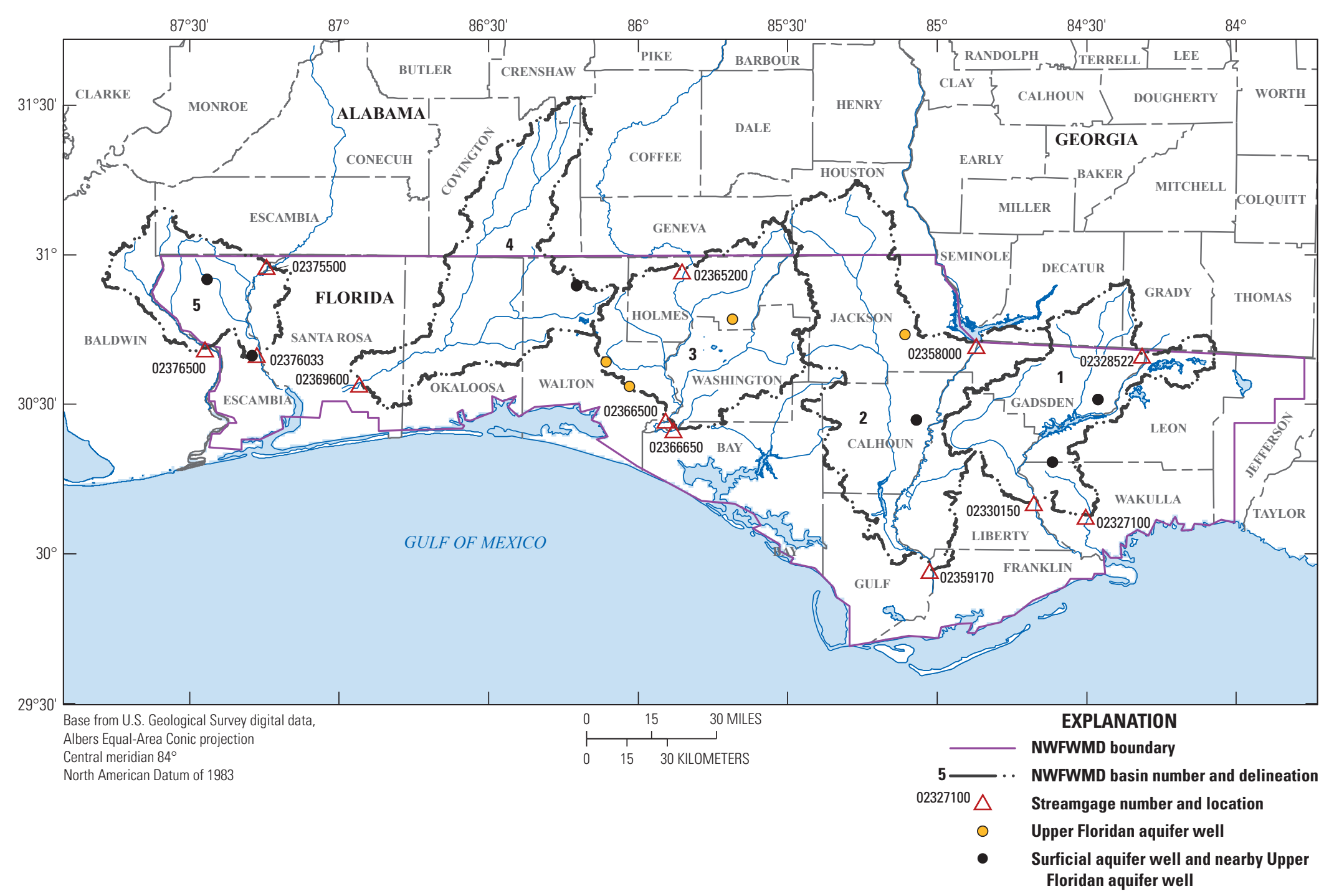

Figure 26. Basin delineations, streamgages at the basin inlets and outlets, surficial and Upper Floridan aquifer wells, major streams, and selected lakes in basins $1-5$ in the Northwest Florida Water Management District (NWFWMD). 


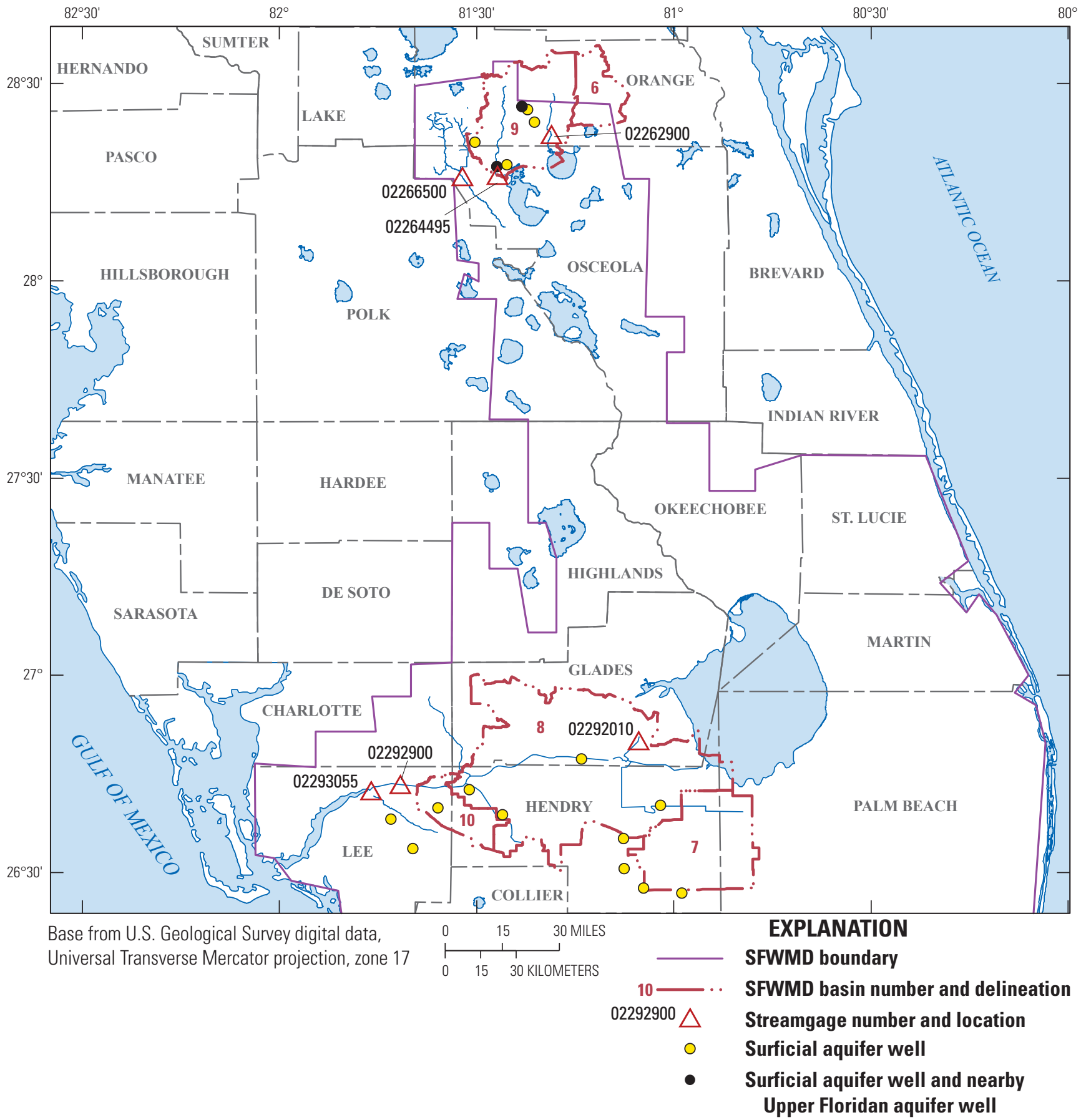

Figure 27. Basin delineations, streamgages at the basin inlets and outlets, surficial and Upper Floridan aquifer wells, and major streams in basins 6-10 in the South Florida Water Management District (SFWMD). 


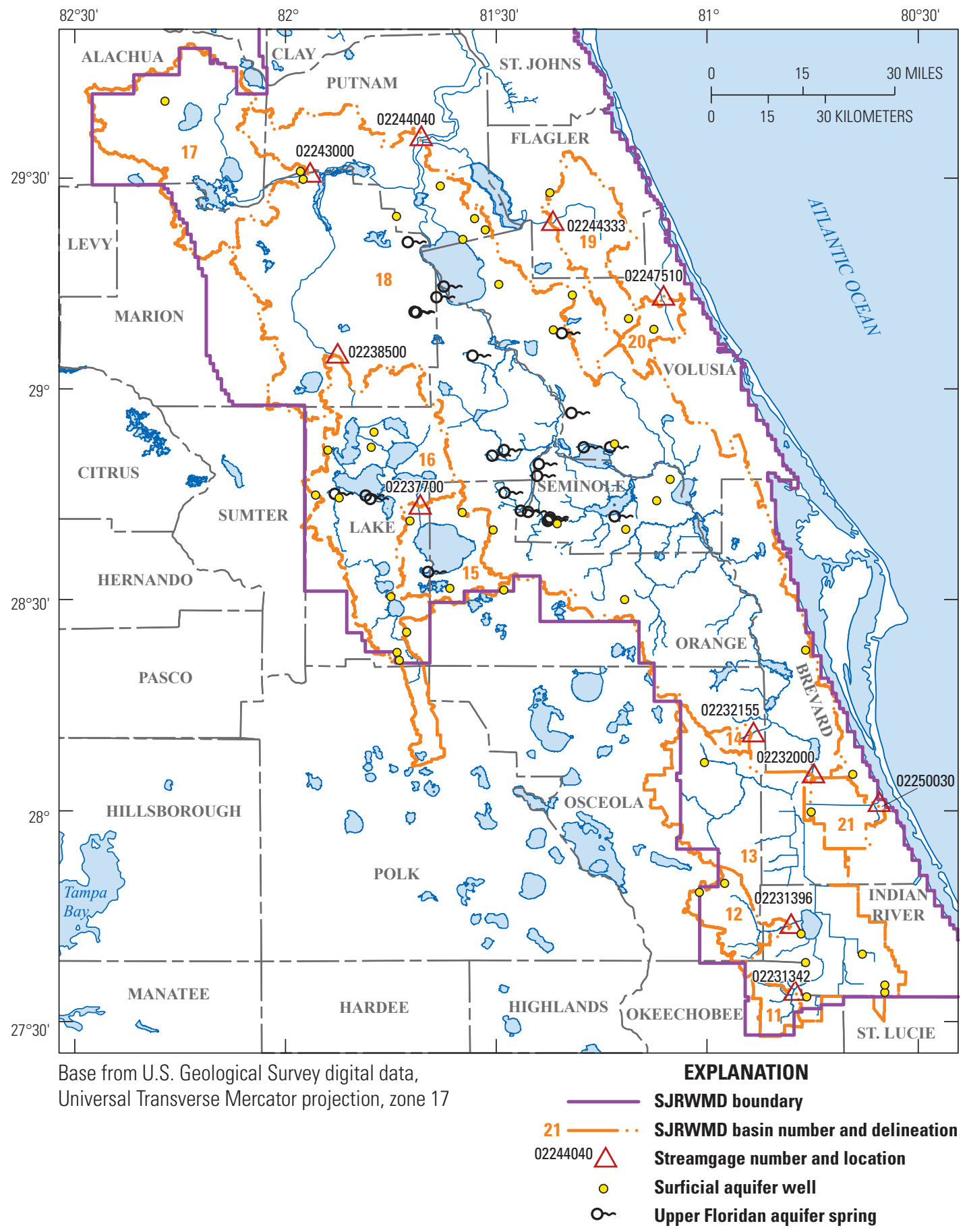

Figure 28. Basin delineations, streamgages at the basin inlets and outlets, surficial aquifer wells, Upper Floridan aquifer springs, and major streams and lakes in basins 11-21 in the St. Johns River Water Management District (SJRWMD). 


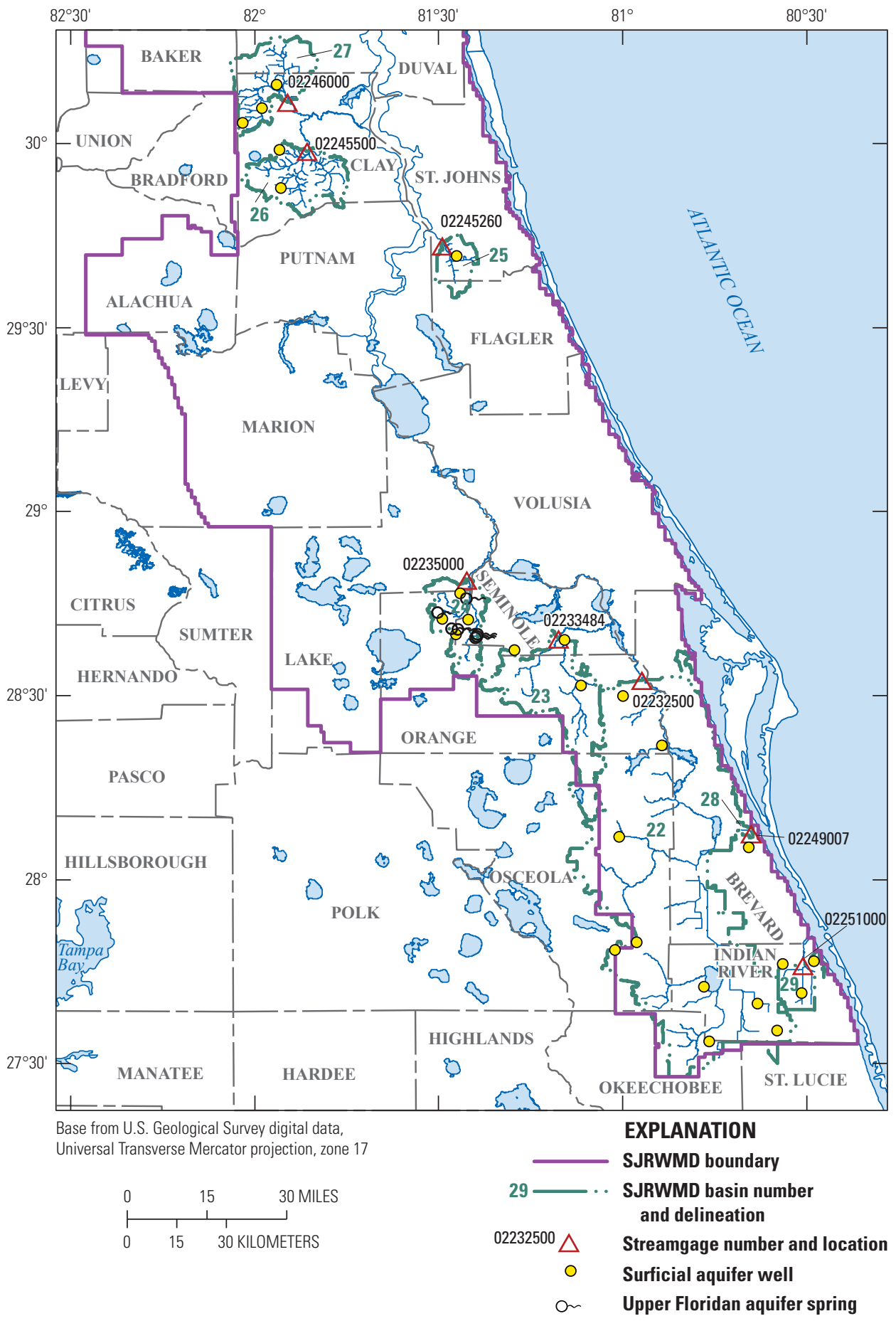

Figure 29. Basin delineations, streamgages at the basin outlets, surficial aquifer wells, Upper Floridan aquifer springs, and major streams and lakes in basins 22-29 in the St. Johns River Water Management District (SJRWMD). 


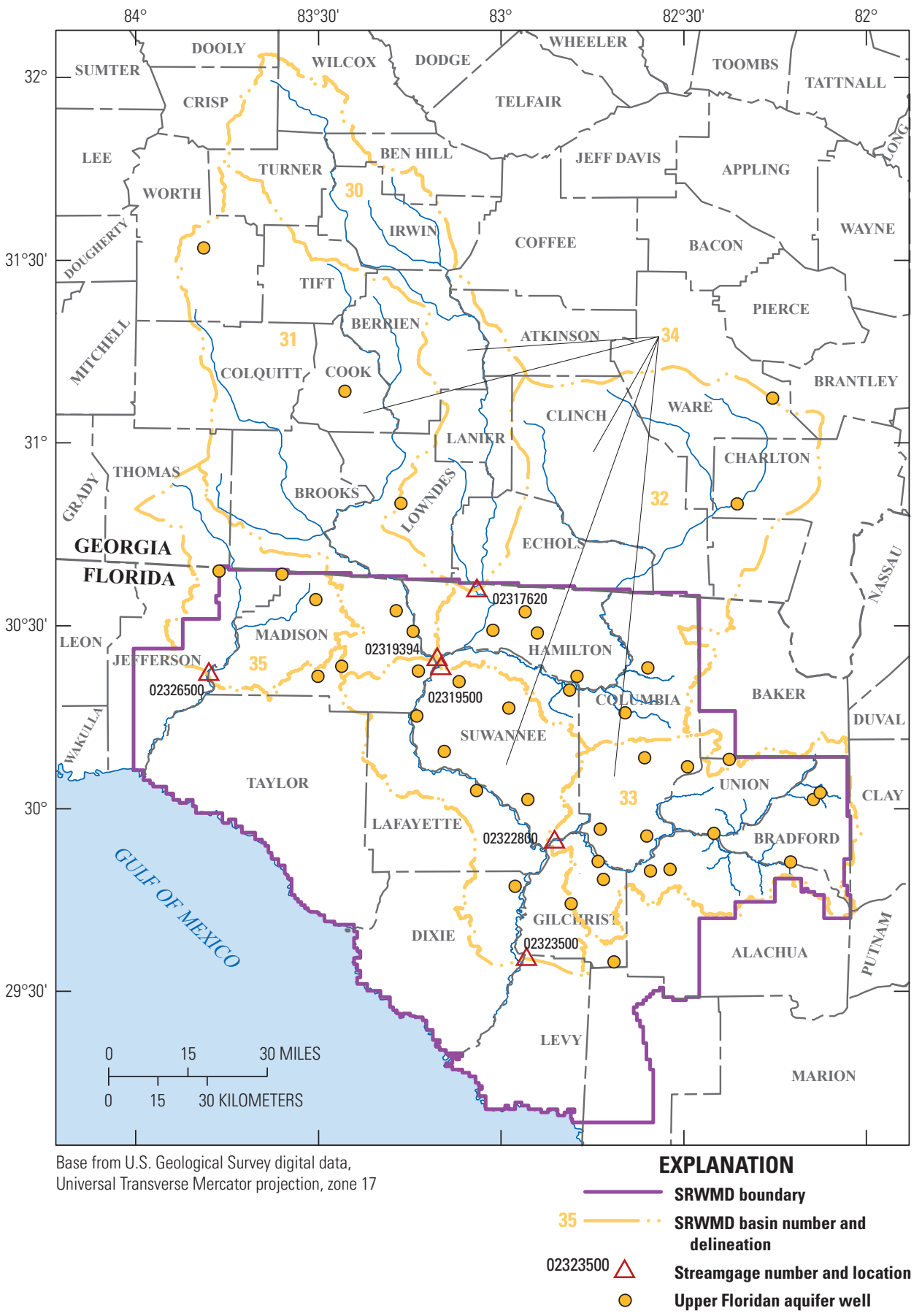

Figure 30. Basin delineations, streamgages at the basin outlets, location of Upper Floridan aquifer wells, and major streams in basins 30-35 in the Suwannee River Water Management District (SRWMD). 
the surface-water basins are presumed to be different from the groundwater basins. Leakage out of the Upper Floridan aquifer for these basins was not considered. Water levels from Upper Floridan aquifer wells were used to calculate annual changes in basin storage. Residuals for basins in the SRWMD ranged from $-0.46 \mathrm{in} / \mathrm{yr}$ for the Santa Fe River Basin (basin 33) to $-3.67 \mathrm{in} / \mathrm{yr}$ for the Suwannee River Basin (number 34; fig. 30; table 14). The associated residuals indicated that SSEBop underestimated annual wbETa by 1.26 and 9.24 percent, respectively.

\section{SWFWMD Basins}

Average annual wbETa, SSEBop, luETa, and SSEBop rates were calculated for basins 36-47 located in the SWFWMD (table 14, fig. 31). Of these 12 basins in SWFWMD, 7 had streamflow data for the entire 2000-17 period to apply the water-balance method (table 14). The control volume for these basins extends from the vegetation canopy to the bottom of the surficial aquifer. Leakage rates for these basins were calculated by using differences in water levels between surficial and Upper Floridan aquifer wells located close to each other and an estimated vertical leakance for each site. Residuals for basins in the SWFWMD ranged from $-3.17 \mathrm{in} / \mathrm{yr}$ for the Shell Creek near Punta Gorda Basin (basin 40) to $0.42 \mathrm{in} / \mathrm{yr}$ for the Saddle Creek at State Road 532 near Lakeland Basin (basin 37; fig. 31; table 14). The associated residuals indicated that SSEBop underestimated wbETa by 8.44 percent and overestimated wbETa by 1.05 percent, respectively.

\section{Tampa Bay Water Basins}

Average annual wbETa, SSEBop, luETa, and SSEBop rates were calculated for basins 48-55 located in the TBW area (table 14, fig. 32). All eight basins had streamflow data for the entire 2000-17 period to apply the water-balance method (table 14). The control volume for these basins extends from the vegetation canopy to the bottom of the surficial aquifer. Leakage rates for these basins were calculated by using differences in water levels between surficial and Upper Floridan aquifer wells close to each other and an estimated vertical leakance for each site. Residuals for basins in the TBW area ranged from $-3.48 \mathrm{in} / \mathrm{yr}$ for the Cypress Creek and Trout Creek Basin (basin 53) to -1.28 in/yr for the Blackwater Creek near Knights Basin (basin 52; fig. 32; table 14). The associated residuals indicated that SSEBop underestimated wbETa by 9.12 percent and underestimated wbETa by 3.50 percent, respectively.

\section{Evaluation of SSEBop at the Statewide Scale}

Bias corrections of monthly SSEBop rates for January 2000-December 2017 based on land-use type were applied to the uncorrected monthly SSEBop gridded datasets (1-km resolution) for Florida and parts of Alabama and Georgia. The SSEBop 2006 rates (uncorrected) are anomalously low near and along the Florida and Georgia coastline (fig. 33A). These low values were replaced by using monthly luETa computed from GOES ETo (note the change in the range of values in the map explanations, fig. $33 B$ ) and were not further bias corrected in the SSEBop rates. The range of bias-corrected SSEBop rates decreased relative to SSEBop rates, generating a smoother spatial surface of 2006 SSEBop rates compared to 2006 SSEBop $_{u}$ rates. Similar results were generated for years other than 2006. The other apparent result of bias correction was the increase in ETa for open-water bodies, such as Lake Okeechobee. Bias-corrected SSEBop rates for Lake Okeechobee are higher than those for neighboring marsh cells southeast of Lake Okeechobee; Lake Okeechobee had been difficult to resolve in maps of SSEBop $u$ rates. A comparison of SSEBop rates for 2006 (figs. 33A, B) and luETa rates derived from GOES ETo (fig. $33 C$ ) indicates that the luETa rates more clearly differentiate lakes from marshes when compared to SSEBop $\mathrm{p}_{\mathrm{u}}$ rates. The minimum, maximum, and average $2006 \mathrm{SSEBop}_{\mathrm{u}}$ rates were 0.00, 69.33, and $41.08 \mathrm{in} / \mathrm{yr}$, respectively, whereas the corresponding 2006 SSEBop rates were 21.39, 76.15, and $37.26 \mathrm{in} / \mathrm{yr}$ (fig. 33).

The minimum, maximum, and average 2006 luETa rates were 24.90, 72.54, and $41.69 \mathrm{in} / \mathrm{yr}$, respectively (fig. 33). The 2006 ranges for the bias-corrected SSEBop and for the 2006 luETa rates were 54.76 (76.15 minus 21.39) and 47.64 (72.54 minus $24.90)$ in/yr, which are substantially less than the 2006 SSEBop range of $69.33 \mathrm{in} / \mathrm{yr}$.

A noticeable transition of luETa rates occurs along the Florida-Alabama and Florida-Georgia State lines (fig. 33C). While the ETo rates used to generate the luETa rates for Georgia and Alabama were obtained from gridMET (Abatzoglou, 2013), the ETo rates used to generate the land-use-derived rates for Florida were obtained from the statewide daily reference and potential evapotranspiration gridded dataset for Florida (USGS, 2018a) because the latter was considered to be based on a higher spatial resolution of solar radiation. The differences between SSEBop and luETa rates could be the focus of future studies aimed at improving the estimation of SSEBop ETa rates by using alternative gridded estimates of ETo. An evaluation of bias corrections of SSEBop rates by multiplying the ETf fraction by alternative estimates of ETo (such as Florida GOES) is beyond the scope of this study. 


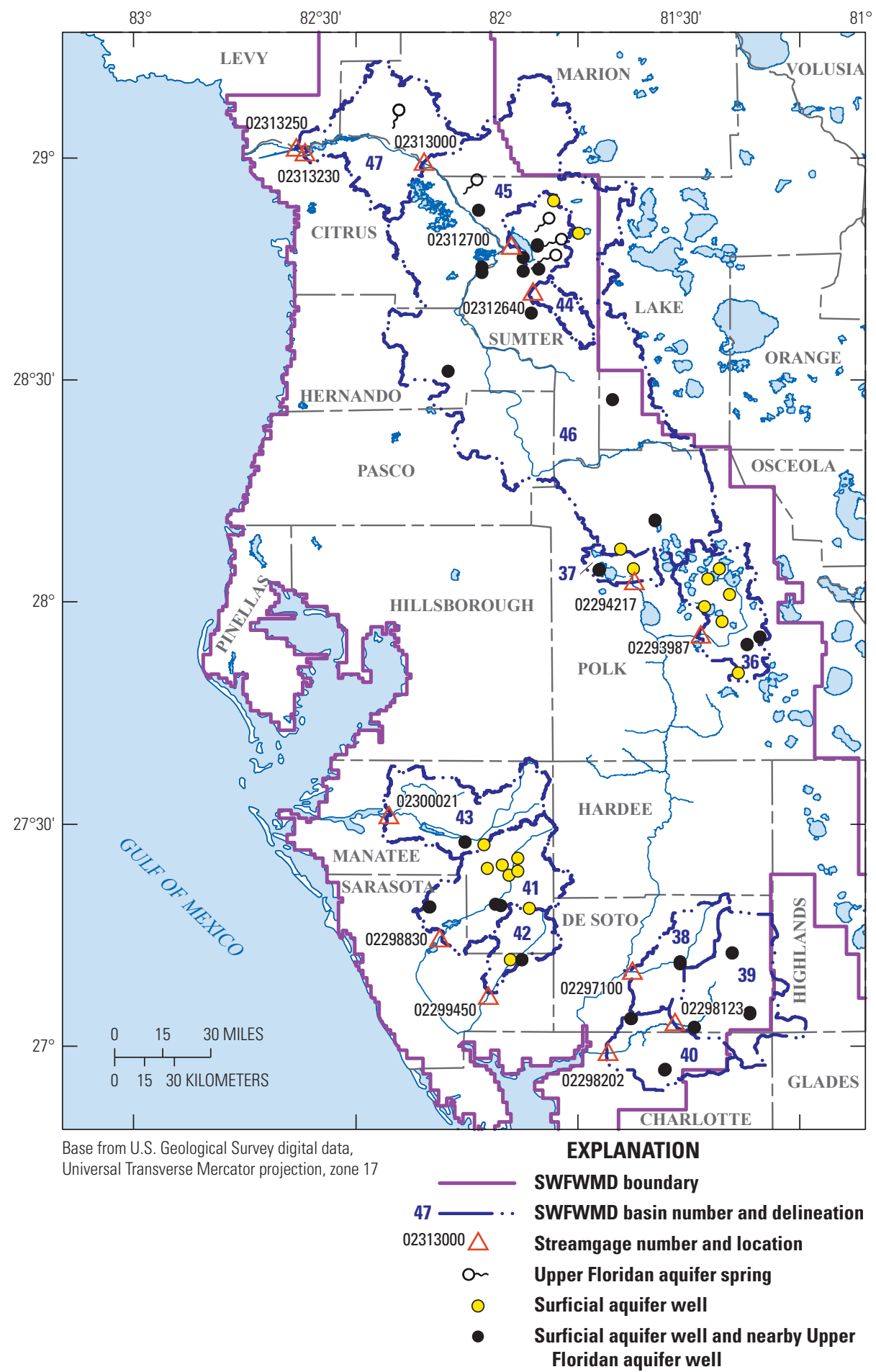

Figure 31. Basin delineations, streamgages at the basin outlets, surficial and Upper Floridan aquifer wells, Upper Floridan aquifer springs, and major streams and lakes in basins 36-47 in the Southwest Florida Water Management District (SWFWMD). 


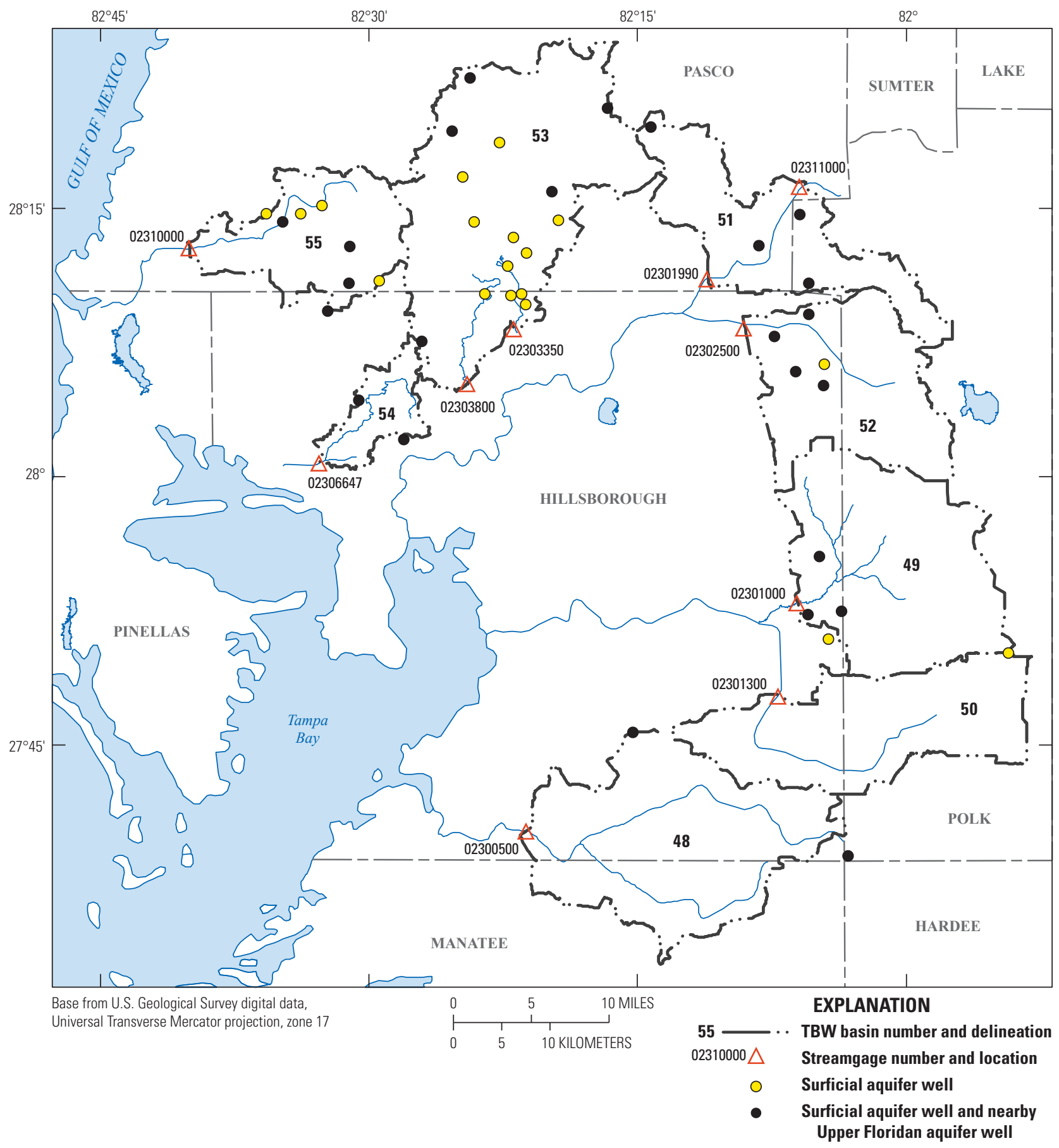

Figure 32. Basin delineations, streamgages at the basin outlets, surficial and Upper Floridan aquifer wells, and major streams in basins $48-55$ in the Tampa Bay Water (TBW) area. 


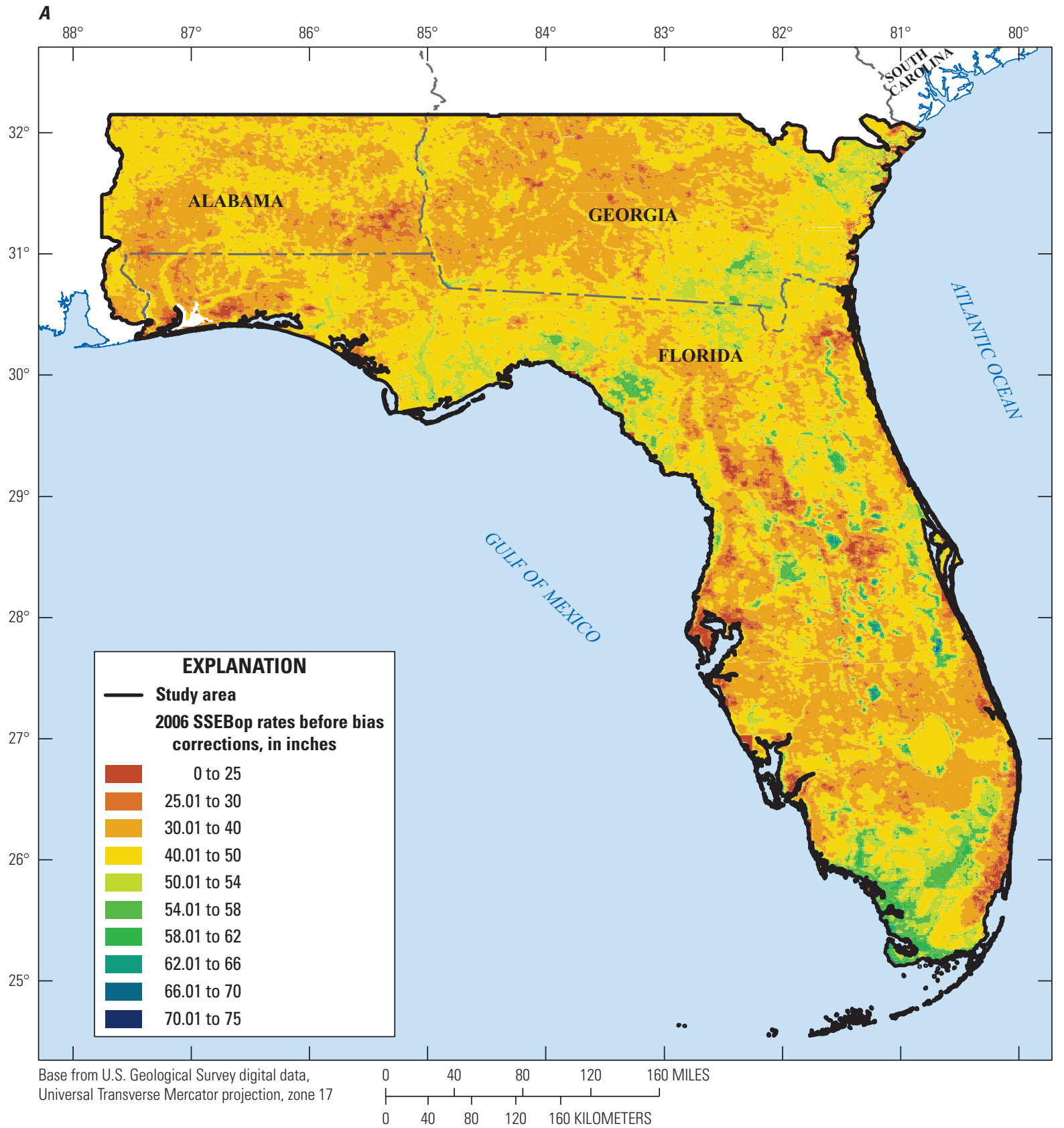

Figure 33. Spatial distribution of, $A$, Operational Simplified Surface Energy Balance (SSEBop) actual evapotranspiration (ETa) rates for 2006 before bias corrections, $B$, SSEBop ETa rates for 2006 after bias corrections, and $C$, land-use-derived ETa rates for 2006 for Florida and parts of Alabama and Georgia. 


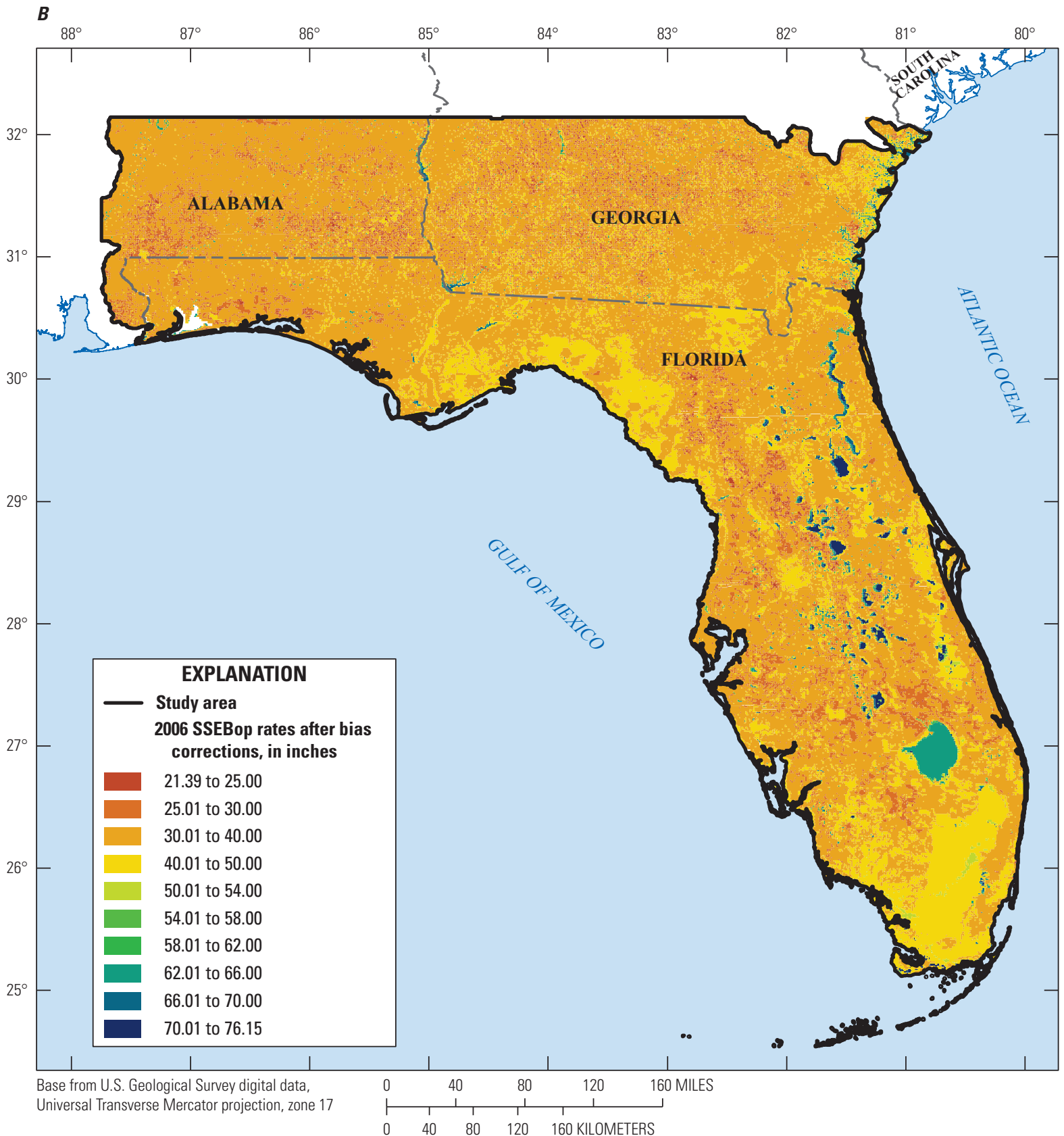

Figure 33. Spatial distribution of, $A$, Operational Simplified Surface Energy Balance (SSEBop) actual evapotranspiration (ETa) rates for 2006 before bias corrections, B, SSEBop ETa rates for 2006 after bias corrections, and $C$, land-use-derived ETa rates for 2006 for Florida and parts of Alabama and Georgia.-Continued 


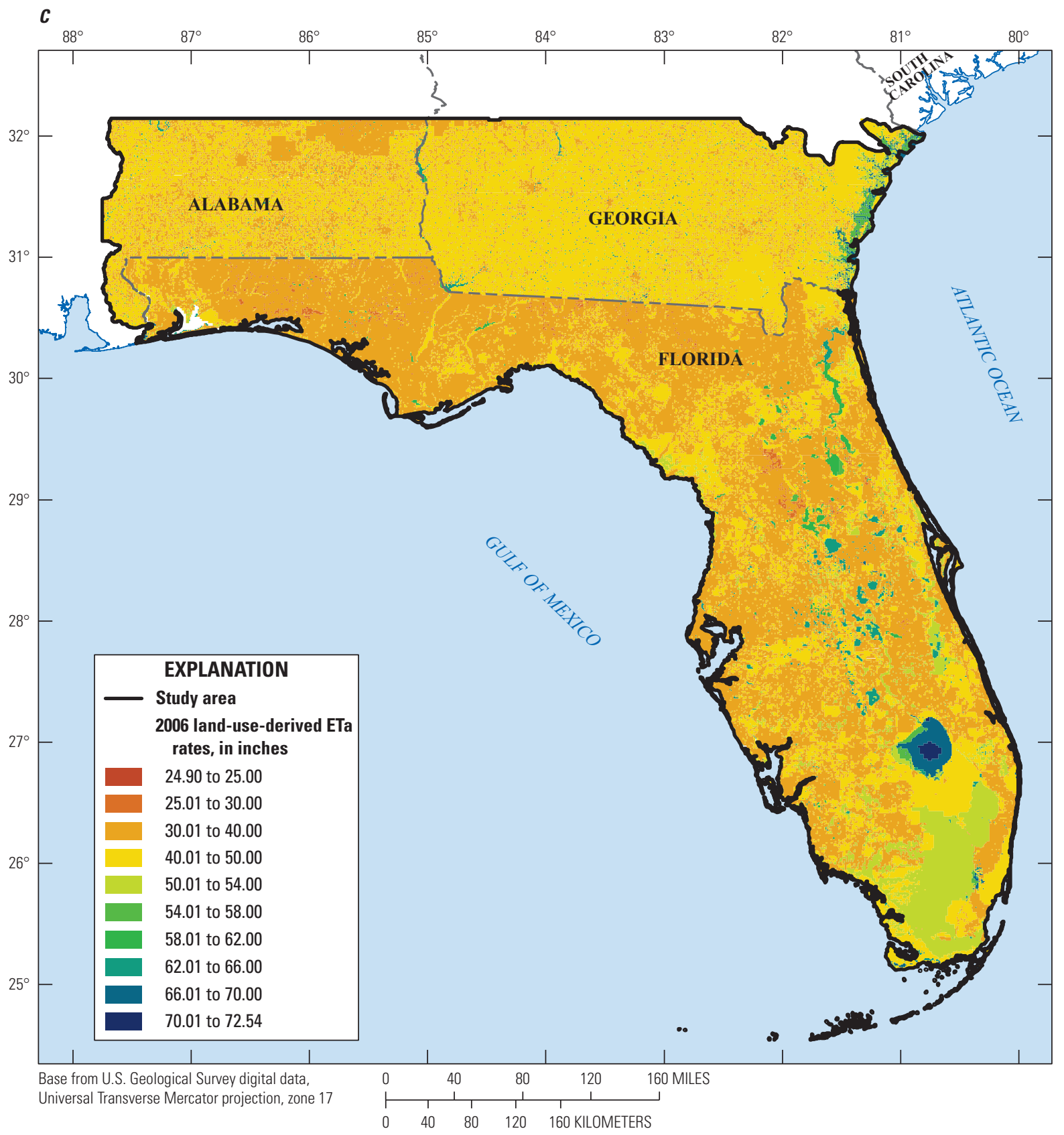

Figure 33. Spatial distribution of, $A$, Operational Simplified Surface Energy Balance (SSEBop) actual evapotranspiration (ETa) rates for 2006 before bias corrections, $B$, SSEBop ETa rates for 2006 after bias corrections, and $C$, land-use-derived ETa rates for 2006 for Florida and parts of Alabama and Georgia._Continued 


\section{Model Limitations}

One of the limitations of the method presented in this study to bias-correct SSEBop rates is the number and the locations of the MEF stations. For example, the urban and forest land-use types are only represented by one station each. Adding MEF station locations might lead to a different set of regression equations for bias correction and could reduce uncertainty in model validation. For example, additional data from MEF stations would allow for verification in the range of SSEBop rates compared to wbETa rates. The model also assumes all urban cells are similar, implying the same population density and the same level of development. The last limitation increases the potential for spatial discontinuities in ETa rates in large cities.

Limitations of the SSEBop $\mathrm{u}_{\mathrm{u}}$ rates are (1) the unrealistically low ETa rates along coastlines, (2) the low ETa rates at large lakes, and (3) the tendency of residuals (mETa minus SSEBop) to decrease as the SSEBop rates increase. A limitation of the luETa rates is the assumption that each generalized land-use type has the same monthly average mETa/ETo ratio for all areas with that same land-use type in the study area. That assumption incorrectly implies, for example, that a marsh, urban, or any specific type of land-use cell in south Florida has the same mETa/ETo ratio as any cell of the same land-use type in Alabama or Georgia. Other limitations of the luETa method are (1) the generalization of all land-use types into just a few land-use types, (2) the assumption that each area designated as one generalized land-use type is assumed to be 100 percent of that land-use type, and (3) the reclassification of generalized land-use types by water-table depth conditions was limited to pasture cells only, but agriculture, forest, urban, and even open-water surfaces could be further reclassified by water-table depth conditions if MEF stations were available at locations with deep and shallow water-table conditions for these land-use types. These limitations are

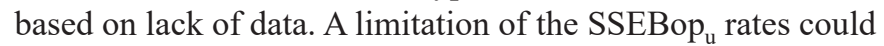
be the use of grass-reference ET (Savoca and others, 2013) as the ETo used to simulate ETa rates for all land uses, which results in the underestimation of the ETa rates for open-water surfaces.

A limitation of the water-balance method is that its application depends on the availability of all inflow and outflow data. The use of groundwater-flow models to calculate leakage rates leaving or entering a basin's control volume has similar errors associated with the flow simulations. An average model residual (measured minus simulated water level) of a few feet in water levels, while typical for a groundwater-flow model, could result in an estimated error in leakage rates of tens of inches per year; thus, using groundwater-flow models to calculate leakage rates could lead to large errors in the water-balance method calculations. This suggests that sound water-balance analyses from measured flows should be used to establish calibration targets for groundwater-flow models and not the reverse. Other limitations of the water-balance method are (1) the uneven spatial distribution of rainfall stations in a basin from which rainfall rates are interpolated, (2) the lack of a uniform distribution of aquifer wells, and if applicable, of gaged lakes, from which reliable changes in basin storage are calculated, (3) the lack of spring-flow measurements, and (4) the differences between delineations of surface-water basins and groundwater basins, which require lateral flows along lateral basin boundaries that are not common to each basin delineation type.

The method presented here to correct biases in differences mETa minus SSEBop could be applied to sites outside of Florida if the number of MEF stations is sufficient to represent the range of land uses of the area of interest.

\section{Summary and Conclusions}

The U.S. Geological Survey (USGS) Operational Simplified Surface Energy Balance (SSEBop) model, which provides estimated actual evapotranspiration (ETa) rates globally at a 1-kilometer resolution, was evaluated over a study area that included Florida and parts of Alabama and Georgia. The SSEBop ETa rates from 2000 to 2017 were compared to ETa rates computed by using data from 24 micrometeorological (met) stations (mETa) across Florida and were used to estimate bias in SSEBop rates at the point scale. Regression equations stratified by generalized land-use types assigned to each station were developed to bias correct SSEBop rate estimates. The generalized land-use types used in this study were agriculture, forest, forested wetland with low to medium canopy density, forested wetland with high canopy density, marsh, pasture under deep water-table conditions, pasture under shallow water-table conditions, urban, and open-water surface. Bias-corrected 2000-17 SSEBop rates were also examined at the basin scale for 55 basins in Florida and parts of Alabama and Georgia. Average annual SSEBop rates were compared to annual ETa rates calculated from the application of the water-balance method (wbETa) to each basin.

The coefficient of determination for monthly mETa rates and the associated SSEBop rates at station grid points was 0.37 before bias corrections and improved to 0.79 after the bias corrections, with improvement reflecting stratification of bias correction by land-use types. Bias correction of SSEBop rates stratified by land-use type reduced the root-mean-square error (RMSE) between monthly mETa and SSEBop rates, on average, from 1.27 inches per month (in/mo) before the bias corrections to $0.73 \mathrm{in} / \mathrm{mo}$ after the bias corrections. RMSE between bias-corrected annual SSEBop rates and annual mETa rates at stations with complete years of record ranged from 2.01 inches per year (in/yr) for the land-use type of agriculture to $5.73 \mathrm{in} / \mathrm{yr}$ for the land-use type of deep-water-table pasture, or 4.96 percent of $40.51 \mathrm{in} / \mathrm{yr}$ and 21.21 percent of $27.03 \mathrm{in} / \mathrm{yr}$, respectively. A low annual average mETa rate of $27.03 \mathrm{in} / \mathrm{yr}$ during dry years at a MEF station in deep-water-table pasture contributed to the percentage error with respect to the 
bias-corrected SSEBop annual rate. At the basin scale, annual average differences between bias-corrected SSEBop rates and rates computed by using the water-balance method for the 55 basins in Florida ranged from -3.67 to $5.29 \mathrm{in} / \mathrm{yr}$ (an underestimation of 9.24 percent to an overestimation of 17.36 percent, respectively, relative to the average annual wbETa rate). The RMSE of annual average residual rates over the 55 basins decreased from $4.13 \mathrm{in} / \mathrm{yr}$ for the uncorrected bias SSEBop rates to $1.95 \mathrm{in} / \mathrm{yr}$ for the bias-corrected SSEBop rates.

Despite model limitations, SSEBop rates were of comparable magnitude to ETa computed by using other methods. Compared to monthly mETa rates for stations and annual wbETa rates for basins, SSEBop rates had a RMSEs of $0.73 \mathrm{in} / \mathrm{mo}$ and $1.95 \mathrm{in} / \mathrm{yr}$, respectively. These RMSEs compare to the average mETa rates for all stations of $3.78 \mathrm{in} / \mathrm{mo}$ and $45.35 \mathrm{in} / \mathrm{yr}$. Given methods used to bias correct basinscale SSEBop estimates, the magnitude of these errors could be extrapolated to statewide-scale applications. These statistics suggest that the bias-corrected SSEBop ETa rates provide a reasonable quantification of the average annual ETa losses in the study area; however, what is reasonable is relative to what is acceptable for a given application. SSEBop bias and accuracy vary based on time step (monthly versus annual), scale (point, basin, statewide), and land-use type. The bias-corrected SSEBop ETa rates could be used as calibration targets in hydrologic studies, knowing that the small percentage of average annual errors ( 3.5 percent) introduced to a calibration process would be well below the margin of error associated with typical residuals in simulation processes, depending on scale. Surface-water and groundwater-flow models with RMSEs on the order of a few feet could benefit from biascorrected SSEBop.

\section{References Cited}

Abatzoglou, J.T., 2013, Development of gridded surface meteorological data for ecological applications and modelling: International Journal of Climatology, v. 33, no. 1, p. 121-131. [Also available at https://doi.org/10.1002/ joc.3413.]

Allen, R.G., Pereira, L.S., Raes, D., and Smith, M., 1998, Crop evapotranspiration - Guidelines for computing crop water requirements - Rome, Food and Agriculture Organization of the United Nations: FAO Irrigation and Drainage Paper 56, accessed July 13, 2020, at http://www.fao.org/3/X0490E/ X0490E00.htm.

Anderson, M., Mecikalski, J.R., and Jacobs, J., 2009, Estimation of actual evapotranspiration over south Florida ALEXI model evaluation: South Florida Water Management District Technical Report, $92 \mathrm{p}$.
Bracho, R., Starr, G., Gholz, H.L., Martin, T.A., Cropper, W.P., and Loescher, H.W., 2012, Controls on carbon dynamics by ecosystem structure and climate for southeastern U.S. slash pine plantations: Ecological Monographs, v. 82, no. 1, p. 101-128. [Also available at https://doi.org/10.1890/11-0587.1.]

Brutsaert, W., 1982, Evaporation into the atmosphereTheory, history and applications: Boston, Kluwer Academic Publishers, 302 p. [Also available at https://doi.org/10.1007/ 978-94-017-1497-6.]

Daly, C., Halbleib, M., Smith, J.I., Gibson, W.P., Doggett, M.K., Taylor, G.H., Curtis, J., and Pasteris, P.P., 2008, Physiographically sensitive mapping of climatological temperature and precipitation across the conterminous United States: International Journal of Climatology, v. 28, no. 15, p. 2031-2064. [Also available at https://doi.org/10.1002/ joc. 1688.]

Florida Geographic Data Library, 2011, Florida Geographic Data Library Search and Download, accessed June 14, 2019, at https://www.fgdl.org/metadataexplorer/explorer.jsp.

German, E.R., 2000, Regional evaluation of evapotranspiration in the Everglades: U.S. Geological Survey WaterResources Investigations Report 00-4217, 48 p. [Also available at https://doi.org/10.3133/wri004217.]

Gnann, S.J., Woods, R.A., and Howden, N.J.K., 2019, Is there a baseflow Budyko curve?: Water Resources Research, v. 55, no. 4, p. 2838-2855. [Also available at https://doi.org/ 10.1029/2018WR024464.]

Griffiths, J.C., 1967, Scientific methods in analysis of sediment: New York, McGraw-Hill Book Company, 508 p.

Helsel, D.R., and Hirsch, R.M., 2002, Statistical methods in water resources-Hydrologic analysis and interpretation: U.S. Geological Survey Techniques of Water-Resources Investigations, book 4, chap. A3, 510 p. [Also available at https://pubs.usgs.gov/twri/twri4a3/twri4a3.pdf.]

Marella, R.L., 2004, Water withdrawals, use, discharge, and trends in Florida, 2000: U.S. Geological Survey Scientific Investigations Report 2004-5151, 136 p. [Also available at https://doi.org/10.3133/sir20045151.]

Marella, R.L., 2009, Water withdrawals, use, and trends in Florida, 2005: U.S. Geological Survey Scientific Investigations Report 2009-5125, 50 p. [Also available at https://doi.org/10.3133/sir20095125.]

Marella, R.L., 2014, Water withdrawals, use, and trends in Florida, 2010: U.S. Geological Survey Scientific Investigations Report 2014-5088, 59 p. [Also available at https://doi.org/10.3133/sir20145088.] 
Marella, R.L., 2020, Water withdrawals, uses, and trends in Florida, 2015: U.S. Geological Survey Scientific Investigations Report 2019-5147, 52 p. [Also available at https://doi.org/10.3133/sir20195147.]

McBride, W.S., Metz, P.A., Ryan, P.J., Fulkerson, M., and Downing, H.C., 2017, Groundwater levels, geochemistry, and water budget of the Tsala Apopka Lake system, westcentral Florida, 2004-12: U.S. Geological Survey Scientific Investigations Report 2017-5132, 100 p. [Also available at https://doi.org/10.3133/sir20175132.]

Mecikalski, J.R., Shoemaker, W.B., Wu, Q., Holmes, M.A., Paech, S.J., and Sumner, D.M., 2018, Highresolution GOES insolation-Evapotranspiration data set for water resource management in Florida, 1995-2015: Journal of Irrigation and Drainage Engineering, v. 144, no. 9, p. 04018025-1-04018025-17. [Also available at https://doi.org/10.1061/(ASCE)IR.1943-4774.0001312.]

Natural Resources Conservation Service, 2020, Soil survey: U.S. Department of Agriculture website, accessed June 2020 at https://www.nrcs.usda.gov/wps/portal/nrcs/ main/soils/survey/.

Priestley, C.H.B., and Taylor, R.J., 1972, On the assessment of surface heat flux and evaporation using largescale parameters: Monthly Weather Review, v. 100, no. 2, p. 81-92. [Also available at https://doi.org/10.1175/15200493(1972)100<0081:OTAOSH>2.3.CO;2.]

Savoca, M.E., Senay, G.B., Maupin, M.A., Kenny, J.F., and Perry, C.A., 2013, Actual evapotranspiration modeling using the operational Simplified Surface Energy Balance (SSEBop) approach: U.S. Geological Survey Scientific Investigations Report 2013-5126, 16 p. [Also available at https://doi.org/10.3133/sir20135126.]

Senay, G.B., 2018, Satellite psychrometric formulation of the operational simplified surface energy balance (SSEBop) model for quantifying and mapping evapotranspiration: Journal of Applied Engineering in Agriculture, v. 34, no. 3, p. 555-566. [Also available at https://doi.org/10.13031/ aea.12614.]

Senay, G.B., Bohms, S., Singh, R.K., Gowda, P.H., Velpuri, N.M., Alemu, H., and Verdin, J.P., 2013, Operational evapotranspiration modeling using remote sensing and weather datasets-A new parameterization for the SSEB ET approach: Journal of the American Water Resources Association, v. 49, no. 3, p. 577-591. [Also available at https://doi.org/10.1111/jawr.12057.]

Senay, G.B., Budde, M., Verdin, J.P., and Melesse, A.M., 2007, A coupled remote sensing and simplified surface energy balance approach to estimate actual evapotranspiration from irrigated fields: Sensors (Basel), v. 7, no. 6, p. 979-1000. [Also available at https://doi.org/10.3390/ s7060979.]
Senay, G.B., Kagone, S., and Velpuri, N.M., 2020, Operational global actual evapotranspiration-Development, evaluation, and dissemination: Sensors (Basel), v. 20, no. 7, p. 1915. [Also available at https://doi.org/10.3390/s20071915.]

Senay, G.B., Verdin, J.P., Lietzow, R., and Melesse, A.M., 2008, Global daily reference evapotranspiration modeling and evaluation: Journal of the American Water Resources Association, v. 44, no. 4, p. 969-979. [Also available at https://doi.org/10.1111/j.1752-1688.2008.00195.x.]

Sepúlveda, N., 2002, Simulation of ground-water flow in the intermediate and Floridan aquifer systems in peninsular Florida: U.S. Geological Survey Water-Resources Investigations Report 02-4009, 130 p. [Also available at https://doi.org/10.3133/wri024009.]

Sepúlveda, N., 2021, Data sets of actual evapotranspiration rates from 2000 to 2017 for basins in Florida and parts of Alabama and Georgia, calculated using the water-balance method, the bias-corrected Operational Simplified Surface Energy Balance (SSEBop) model, and the land-use crop coefficients model: U.S. Geological Survey data release, https://doi.org/10.5066/P99AB3X4.

Sepúlveda, N., Fulkerson, M., Basso, R., and Ryan, P.J., 2018, Effects of surface-water and groundwater inflows and outflows on the hydrology of the Tsala Apopka Lake Basin in Citrus County, Florida: U.S. Geological Survey Scientific Investigations Report 2018-5055, 137 p. [Also available at https://doi.org/10.3133/sir20185055.]

Shoemaker, W.B., 2018, Evapotranspiration within Blue Cypress Marsh, Vero Beach, Florida, 2015 to 2018: U.S. Geological Survey data release, accessed January 10, 2020, at https://doi.org/10.5066/P9TKLDND.

Shoemaker, W.B., Lopez, C.D., and Duever, M., 2011, Evapotranspiration over spatially extensive plant communities in the Big Cypress National Preserve, southern Florida, 2007-2010: U.S. Geological Survey Scientific Investigations Report 2011-5212, 46 p. [Also available at https://doi.org/10.3133/sir20115212.]

Southwest Florida Water Management District [SWFWMD], 2019, Southwest Florida Water Management District Geospatial Open Data Portal, accessed June 14, 2019, at https://data-swfwmd.opendata.arcgis.com/.

St. Johns River Water Management District, 2016, Recharge to the Upper Floridan aquifer in the St. Johns River Water Management District, Florida: St. Johns River Water Management District Technical Fact Sheet SJ2016-FS1, 5 p., accessed June 14, 2019, at https://hub.arcgis.com/ datasets/e740bfd1d37f46fea0e39529f18bd91c_0. 
Sumner, D.M., 2006, Adequacy of selected evapotranspiration approximations for hydrologic simulation: Journal of the American Water Resources Association, v. 42, no. 3, p. 699-711. [Also available at https://doi.org/10.1111/ j.1752-1688.2006.tb04486.x.].

Sumner, D.M., 2017, Evapotranspiration (ET) at Blue Cypress marsh site, daily data, Indian River County, Florida, June 1, 1995-October 20, 2014: U.S. Geological Survey data release, accessed January 10, 2018, at https://doi.org/ 10.5066/F7CR5RHB.

Sumner, D.M., Hinkle, C.R., and Becker, K.E., 2017, Evapotranspiration (ET) at University of Central Florida urban site, daily data, Orange County, Florida, January 29, 2009-September 27, 2012: U.S. Geological Survey data release. [Also available at https://doi.org/10.5066/ F7JS9NZB.]

Swancar, A., 2015, Comparison of evaporation at two central Florida lakes, April 2005-November 2007: U.S. Geological Survey Open-File Report 2015-1075, 16 p. [Also available at https://doi.org/10.3133/ofr20151075.]

Swancar, A., 2016, Evapotranspiration (ET) data at Dead River forested wetland site, Hillsborough County, Florida, December 2009-February 2016: U.S. Geological Survey data release, accessed January 10, 2018, at http://dx.doi.org/ 10.5066/F7HT2MFK.

Swancar, A., 2017a, Evapotranspiration data at Starkey pasture site, Pasco County, Florida, January 2010-April 2016: U.S. Geological Survey data release, accessed January 10, 2018, at https://doi.org/10.5066/F7SF2TD9.

Swancar, A., 2017b, Evapotranspiration (ET) data at Immokalee row crop site, Collier County, Florida, September 22, 2008-January 8, 2009: U.S. Geological Survey data release, accessed January 10, 2018, at https://doi.org/10.5066/F7QZ284N.

Thornton, P.E., Thornton, M.M., Mayer, B.W., Wei, Y., Devarakonda, R.S., Vose, R., and Cook, R.B., 2016, Daymet-Daily surface weather data on a $1-\mathrm{km}$ grid for North America, version 3: Oak Ridge, Tennessee, Oak Ridge National Laboratory Distributed Active Archive Center for Biogeochemical Dynamics online database. [Also available at https://doi.org/10.3334/ ORNLDAAC/1328.]

University of California, Merced, 2020, Climatology Lab: University of California, Merced, website, accessed August 6, 2020, at http://www.climatologylab.org/.
U.S. Department of Agriculture, 2007, National Soil Survey Handbook, title 210-VI-NEH: Washington, D.C., Natural Resources Conservation Service. [Also available at https://directives.sc.egov.usda.gov/OpenNonWebCon tent.aspx? content $=17757$.wba.]

U.S. Geological Survey, 2015, National Land Cover Database, accessed January 10, 2018, at https://www.usgs.gov/centers/ eros/science/national-land-cover-database.

U.S. Geological Survey, 2018a, Evapotranspiration information and data: U.S. Geological Survey Caribbean-Florida Water Science Center website, accessed March 26, 2018, at https://www.usgs.gov/centers/car-fl-water/science/ reference-and-potential-evapotranspiration.

U.S. Geological Survey, 2018b, USGS water data for the Nation: U.S. Geological Survey National Water Information System database, accessed January 10, 2018, at http://dx.doi.org/10.5066/F7P55KJN.

U.S. Geological Survey, 2018c, Index of /project/SSEBop/ MODIS: U.S. Geological Survey web page, accessed January 5, 2021, at https://edcftp.cr.usgs.gov/project/ SSEBop/MODIS/.

U.S. Geological Survey, 2020, Welcome to the USGS Geo Data Portal, accessed January 10, 2020, at https://cida. usgs.gov/gdp/.

Velpuri, N.M., Senay, G.B., Singh, R.K., Bohms, S., and Verdin, J.P., 2013, A comprehensive evaluation of two MODIS evapotranspiration products over the conterminous United States-Using point and gridded FLUXNET and water balance ET: Remote Sensing of Environment, v. 139, p. 35-49. [Also available at https://doi.org/10.1016/j.rse.2013.07.013.]

Wacker, M.A., and Shoemaker, W.B., 2018, Evaporation at LZ40 platform, Lake Okeechobee, Palm Beach County, Florida, 2016: U.S. Geological Survey, South Florida Information Access, Data Exchange website, accessed April 9, 2020, at https://sflwww.er.usgs.gov/exchange/ evapotrans/index.php.

Zhang, K., Kimball, J.S., Nemani, R.R., and Running, S.W., 2010, A continuous satellite-derived global record of land surface evapotranspiration from 1983 to 2006: Water Resources Research, v. 46, no. 9, W09522. [Also available at https://doi.org/10.1029/2009WR008800.] 
For more information about this publication, contact Director, Caribbean-Florida Water Science Center U.S. Geological Survey 4446 Pet Lane, Suite 108 Lutz, FL 33559

For additional information visit https://www.usgs.gov/centers/car-fl-water

Publishing support provided by Lafayette Publishing Service Center 


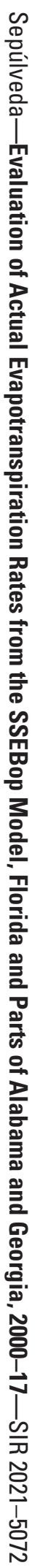

